\title{
Mesterséges intelligencia
}

INTERDISZCIPLINÁRIS E-FOLYÓIRAT

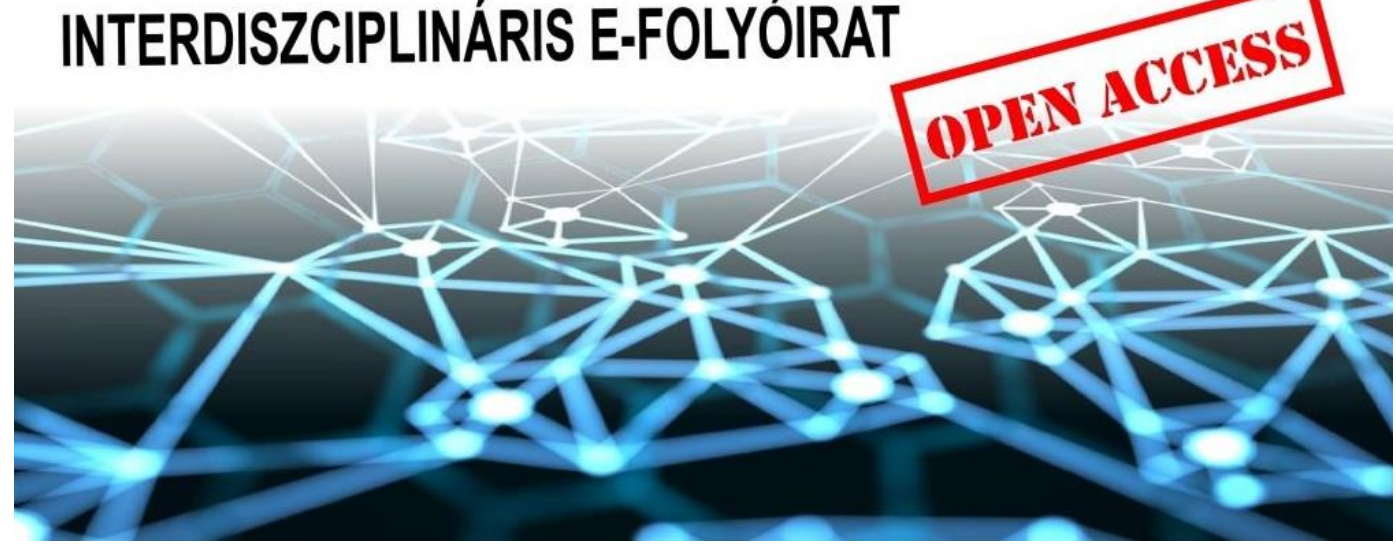

DOI 10.35406/MI.2021.1.1

ISSN 2676-9611

III. évfolyam 2021/1. szám

WEB: www.kpluszf.com

K+F STÚDIÓ Kft.

$a z$

MI koalíció 


\title{
IMPRESSZUM
}

\section{MESTERSÉGES INTELLIGENCIA}

\author{
Interdiszciplináris e-folyóirat \\ Alapítva: 2019-ben. \\ ISSN 2676-9611
}

A Nemzeti Média- és Hírközlési Hatóság Hivatala a médiaszolgáltatásokról és a tömegkommunikációról szóló 2010. évi CLXXXV. törvény 46.§ (4) bekezdése alapján nyilvántartásba vett sajtótermék (határozatról szóló értesítés iktatószáma: CE/5420-5/2019).

A Mesterséges intelligencia interdiszciplináris e-folyóirat a K+F Stúdió Kft. által, társadalmi felelősségvállalási (CSR) stratégia keretében alapított és kiadott, negyedévente megjelenő Open Access (nyílt hozzáférésű) internetes periodika, melyben két anonim és két nem anonim szakmai lektor bírál minden tanulmányt.

\section{A Kiadó adatai:}

Kiadó: K+F Stúdió Kft.

A kiadó székhelye: 4032 Debrecen, Tarján utca 55.

Mobil: +36-30-4849779

E-mail:info@kpluszf.com

Web: www.kpluszf.com

Kiadásért felelós személy: Mező Katalin (PhD)

\section{A Szerkesztőség adatai:}

Levélcím: K+F Stúdió Kft., 4032 Debrecen, Tarján utca 55. Mobil: +36-30-4849779

E-mail: info@kpluszf.com

Web: www.kpluszf.com

Alapitó föszerkesztô: Mező Ferenc (PhD)

Tördeló szerkesztô: Mező Katalin (PhD), Örsi Balázs (Drs.)

\section{Együttmüködő civil szervezet:}

Kocka Kör Tehetséggondozó Kulturális Egyesület (www.kockakor.hu)

\section{Szerkesztőség (ABC rendben):}

Bodnár Gabriella, (PhD, habil., Soproni Egyetem)

Kelemen Lajos (PhD, OKOSKOCKA Kft.)

Mező Ferenc (PhD, K+F Stúdió Kft.)

Mező Katalin (PhD, Debreceni Egyetem)

Orbán Réka (PhD, Babes-Bolyai Egyetem)

Pénzes Dávid (PhD, Káldor Miklós Kollégium)

Pšenáková Ildikó (PhD, Trnava University in Trnava, Szlovákia)

Roskó Tibor (Drs, Debreceni Egyetem)

Simó Ferenc Zoltán (dr., LL.M, Debreceni Egyetem)

Szabóné Balogh Ágota (PhD, Gál Ferenc Fóiskola)

Szűts Zoltán (PhD, Budapesti Múszaki és Gazdaságtudományi Egyetem)

Tomac, Zvonimir (PhD, University J.J. Strossmayera of Osijek, Horvátország)

Vass Vilmos (PhD, habil., Budapesti Metropolitan Egyetem, Selye János Egyetem)

Vámos Tibor (Prof. Dr., akadémikus, MTA SZTAKI)

Külön nem hivatkozott illusztrációk forrása: https://pixabay.com 


\section{TARTALOM}

SZERKESZTŐI KÖSZÖNTŐ

ELMÉLETI ÉS EMPIRIKUS TANULMÁNYOK

Zorkóczy Miklós:

AI VISION \#1 - GOODBYE ASYMMETRIC INFORMATION FOR PATIENTS?!

Ujfaludi László:

FANTÁZIAKÉPEK AZ UNIVERZUMRÓL - ÜRMŰVÉSZET (SPACE ART)

Simó Ferenc Zoltán:

PRELIMINARY OBSERVATIONS ON AI REGULATION

Németh János:

NYILVÁNOSSÁG A BÜNTETŐELJÁRÁSBAN:

A JÁRVÁNYHELYZET EGY ÚJABB KÉRDÉSES PONTJA

MÓDSZERTANI TANULMÁNYOK

Szabó Dániel:

CSÍPŐPROTÉZISEK BERÖGZÜLÉSÉNEK ÉS ÉLETTARTAMÁNAK OPTIMALIZÁLÁSI

LEHETŐSÉGE FÉMNYOMTATÁS ÉS MESTERSÉGES INTELLIGENCIA SEGÍTSÉGÉVEL73

Tomáš Godiš:

MODERN TECHNOLOGIES AND FOREIGN LANGUAGE TEACHING

MÜHELY, RENDEZVÉNY

LEGYEN ÖN IS AZ ELSŐ SZÁZEZER KÖZÖTT,

AKI TELJESÍTI AZ MI KIHÍVÁS MESTERSÉGES INTELLIGENCIA ALAPOZÓT!

Borbélyné Bacsó Viktória, Szabó Dániel Dénes, Farkas Máté János és Ujvári Balázs:

ERDŐTÜZEK DINAMIKÁJÁNAK VIZSGÁLATA

A MEDGYESSY FERENC GIMNÁZIUMBAN

A MESTERSÉGES INTELLIGENCIA IS SZÓBA KERÜLT

A „HÖLGYEK A TUDOMÁNYBAN (2020/2021)” PROJEKT

TEHETSÉG TANÁCSADÁST CÉLZÓ WORKSHOPJAIN.

AZ „INNOVÁCIÓS STÚDIUM (2020/2021)” PROJEKT

ÉS A MESTERSÉGES INTELLIGENCIA 


\section{SZERKESZTŐI KÖSZÖNTŐ}

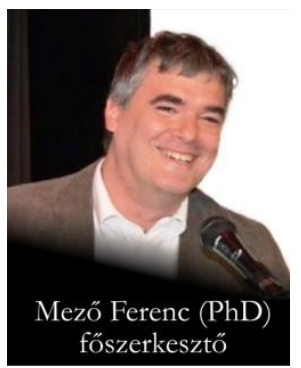

Tis ఇৃtelt Olvasó!

Üdvözöljük a Mesterséges intelliegencia folyóirat III. évfolyam 2021/1. számának megjelenése alkalmából!*

A lapszám a korábbiakhoz hasonlóan ismét demonstrálja a mesterséges intelligencia témához sokféle módon történő kapcsolódási lehetőséget.

Az első tanulmányban dr. Zorkóczy Miklós osztja meg velünk egy egészségügyi környezetben elképzelt, MI-re épülő fiktív innováció egy lehetséges - igen életszerű - vízióját.

Prof. Ujfaludi László a Space Art (űrművészet) világába kalauzolja az Olvasót. Az űrmúvészet sajátosan ötvözi a tudományos ismereteket a múvészeti igényű megjelenítéssel, s ezzel többek között jól szolgálja a tudománynépszerűsítést is. Az ûrművészet két zsálon kapcsolódik az MI témához: egyrészt az űrkutatás eszközként használja az MI-t, aminek eredményeként a space art alkotások is létrejöhetnek. Másrészt tanulságos lehet párhuza-

\footnotetext{
*Az MI témakörrel ismerkedők számára bevezető tanulmányként javasoljuk: Mező Ferenc (2019): Interdiszciplináris kapcsolódási lehetőségek a mesterséges intelligenciára irányuló cél-, eszköz- és hatásorientált kutatáshoz. Mesterséges intelligencia - interdiszciplináris folyóirat, I. évf. 2019/1. szám. 9-29. doi: 10.35406/MI.2019.1.9
}

mot vonni a space art ûrkutatást népszerűsítő hatása és felhasználása, illetve az MI népszerűsítésével kacsolatos lehetőségek között.

Dr. Simó Ferenc Zoltán angol nyelvű esszéjében a mesterséges intelligencia jogi szabályozásával kapcsolatos észrevételeit tárja a nyilvánosság elé.

Németh János ugyancsak jogi vonatkozású írása pedig a büntetőeljárások (többek között) digitalizációval járó nyilvánosságának kérdéses pontjaira hívja fel a figyelmet.

Szabó Dániel a mesterséges intelligencia szereplehetőségét (is) vázolja interdiszciplináris megközelítésű tanulmányában. Rámutatt arra, hogy milyen szerepe lehet az MI-nek a fémnyomtatással előállított csípőprotézisek berögzülése és élettratamának optimalizálása terén.

Tomáš Godiš az idegen nyelv tanulás terén használható korszerű technológiákat, alkalmazásokat mutat be tanulmányában.

A lapszám négy mủhely, rendezvény bemutatását tartalmazza. Ezek:

A Mesterséges Intelligencia Koalíció az „MI Kihívás” teljesítésére invitálja az Olvasókat. A Mesterséges Intelligencia Koalíció jelenleg több mint ezer szakértőt, s 330 tagszervezetet, fog össze - 2021. januárjától e lap kiadója, a $\mathrm{K}+\mathrm{F}$ Stúdió $\mathrm{Kft}$. is tagszervezete az MI Koalíciónak.

Borbélyné Dr. Bacsó Viktória és szerzőtársai a debreceni Medgyessy Ferenc Gimnázium, Mûvészeti Szakgimnázium és Technikum, valamint a Debreceni Egyetem Fizikai 
Innovációs Kutatóműhelyének együttműködésében, középiskolás diákok bevonásával megvalósuló kutatómúhely munkáját mutatják be. A középiskolás diákok erdőtüzek alakulásának megismeréséhez használható autonóm kommunikációra képes mérōállomás prototípusához szükséges szenzorokat teszteltek a múhelymunka során.

A $\mathrm{K}+\mathrm{F}$ Stúdió Kft. „Hölgyek a tudományban (2020/2021)” projektje keretében megvalósuló „Anya és lánya” tehetségtanácsadás célú workshopok, illetve „Innovációs Stúdium (2020/2021)" projektjeivel kapcsolatos rövid közlemények zárják a lapszámot. Mindkét projekt támogatója a Nemzeti Tehetség Program.

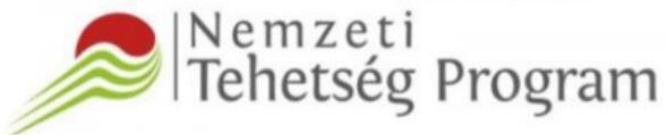

Gondolatébresztő és tanulmány beküldésére motiváló olvasást kíván Önnek a Szerkesztőség nevében is:
Dr. Mező Ferenc

alapító főszerkesztő 


\section{ELMÉLETI ÉS EMPIRIKUS TANULMÁNYOK}




\title{
AI VISION \#1 - GOODBYE ASYMMETRIC INFORMATION FOR PATIENTS?!
}

Szerző:

Dr. Zorkóczy Miklós Zorkóczy Ügyvédi Iroda

Szerző e-mail címe: miklos@drzorkoczy.hu
Lektorok:

\author{
Mező Ferenc (PhD) \\ Eszterházy Károly Egyetem \\ Simó Ferenc Zoltán (Dr. Jur.) \\ Debreceni Egyetem
}

...és további két anonim lektor

\begin{abstract}
Absztrakt
A telemedicina szárnyán, egy vállalkozó orvos szemszögéből részt vehetünk egy Üzleti Angyal befektésben és exitben, megnézhetjük az orvosi társadalom szempontjait, majd a piaci kudarcot egy újabb VC befeketés menti meg, létrejön a kormányzati szabályozás, és intézményesül az innováció. A tanulmány jogi, közgazdasági, egészségügyi, adatvédelmi témákat érint, azokat összefüggéseiben tárgyalja, felvetítve egy elképzelt jövőbeli mesterséges intelligencia által támogatott technológiai és egészségügyi - társadalmi jövőképet.
\end{abstract}

Kulcsszavak: Egészségügyi jog, Mesterséges Intelligencia, Telemedicina, adatvédelem

Diszciplinák: orvostudomány, jogtudomány, közgazdaságtudomány

\section{Abstract \\ AI VÍZIÓ \#1 \\ - VISZL ÁT BETEGEKNEK SZÓLÓ ASZIMMETRIKUS INFORMACIÓK?!}

Having a ride in a future $\mathrm{AI}$ investment project, you can see a telemedicine start up from a physician point of view, you will see a Business Angel investment and exit, also a market failure cured by a VC investment, a government ruling and finally the vision of innovation. The article is about legal, economic, medical and data privacy issues and their close consequences in a future AI innovation.

Keywords: medical law, AI, telemedicine, Healthcare, data privacy

Disciplines: medicine, law and economy

Zorkóczy Miklós (2021): AI Vision \#1 - Goodbye asymmetric information for Patients?! Mesterséges intelligencia - interdiszciplináris folyóirat, III. évf. 2021/1. szám. 9-17. doi: 10.35406/MI.2021.1.9 
Patients, Physicians, Social Funds, VCs and Regulatory were all happy, though they had not had any trust in using AI at the beginning. Having a ride in a future AI investment project, you can see a telemedicine start up from a physician point of view, you will see a Business Angel investment and exit, also a market failure cured by a VC investment, a government ruling and finally the vision of innovation. The article is about legal, economic, medical and data privacy issues and their close consequences in a future $\mathrm{AI}$ innovation.

\section{Asymmetric information in Healthcare}

Once upon a time, a Medical Resident recognized that the leaflets at the reception desks in his/her hospital were not up to date. The receptionists were not always well informed about the changes, and sometimes the quality of information the Patient received were depending on the personal current ability to answer. While the Resident was responsible to give proper information to Patients of his/her medical care to have the consent for the treatment, Residents realized that so much information was about non - medical questions though he/she was not experienced to answer them or was not up to dated. Why not to digitalize it and automatize the whole info process? - he asked.

It was obvious that the informed consent of any medical treatment could not rely on "smart computers". Patients' point of view he/she would not understand fully his/her diagnosis, the available care and therapy, the costs and efficiency, the costs and efficacy. So, he/she would rely on his doctor's (as an agent) opinion and based on this suggestion he/she (as Mandator) would give the consent on the treatment. If an Agent made the decision, and he/she was part of the service, this would be the situation when supplier induced demand. Monopoly situation which could be balanced by medical guidelines and protocols or make patients financially interested to get as much as information available by a mechanism of co-insurance, co-payment, deductibles (Gulácsi, 2005). The lack of proper information to give informed consent let lawyers easy to win in front of a court to claim for compensation on behalf of patients instead of demand compensation for medical malpractice. This was the reason why hospitals would not approve to give information indirectly via outside telemedicine solutions, since the hospital would be responsible in such court actions. To avoid such cases, hospitals had their own policies and protocols to inform the Patient as their local specialties. So, the info asymmetry still stood against Patient which could be balanced by legal or financial mechanisms.

\section{Startup}

The young Medical Resident met IT fellows and lawyers to find out how to save time for medical professionals and give 
Patients more info. The IT solution collected information from hospitals and could satisfy Patients (like consumers) to manage an always available, a researchable, a printable, and an up-to-date webpage. None of the hospitals wanted to be partner since the legal difficulties of giving proper information was legal risk for them, but a Business Angel found the market niche, lots of computable data and lots of customers always meant big profit. The investment process was not easy, black box affect, regulatory issues, the negative and defensive approach of hospitals made the business plan uncertainty, and it was extremely hard to draft a joint venture agreement. The Busines Angel was engaged to make investments which had social impact, in this way he/she could agree in such a risky term sheet.

\section{Market proof}

As a result of the investment, the "medical yellow pages" (hereinafter Teledoc) was launched and set up a common platform for the Hospitals and Patients. Teledoc was free for everyone, including any service providers. First, they collected useful but non-medical information, Teledoc took over the management of useful information and it was a public interest. Teledoc became a trusted source of information, it was popular among Patients. General medical information like how to get prepared for blood collection, when and what to eat or drink before and after it. Teledoc system developed itself like deep learning mechanism, the Patient asked, and the Physicians answered. In this way Teledoc system developed a huge database case by case, which was clean, systematic, and professional. Also, each hospital features could also be handled in accordance with local protocols, the Patient could choose how to get prepared for treatment according to his/her place of residence. For example, what is expected in the local hospital in case of maternity, what "hospital package" should be prepared, what was allowed to take to hospitals and what was not, what baby clothes and things could be taken, when and who could visit the maternity department. The development of telemedicine was the next step to become popular, and other policlinic and primary care providers wanted to join. They used a booking system, which was available free of charge to all participants. It was only one step to contact the doctor directly via the Teledoc's infrastructure, either over the web or even over the phone, to avoid tumult and waiting in the corridors. The revenue corners of Teledoc also developed as planned, and pharmaceutical companies, private providers, lifestyle, and wellness companies immediately joined Teledoc, which now has thousands of registered users and dozens of institutions. With profits from sponsorship fees and other advertising, the 4-person management was able to buy out the initial investor, who were able to exit his/her investments at a high return. 


\section{Market failure}

Telemedicine companies such as Teledoc became popular, and the control authorities received more complaints about such companies, and also the majority of the health society was not happy either. While some healthcare professionals noticed that they were able to spend more time dealing with the Patients, they already arrived well informed for the examinations. Yet most doctors felt tired and frustrated by the way Patients handled the information they had received via Teledoc and other Telemedicine Companies, and doctors' response to questions generated three other questions. Some Patients even asked their doctors to have more available tests or other treatments. It remained the responsibility of service provider's to obtain the Patient's consent for the treatment, and unregulated telemedicine providers had confused the previous established communication habits of doctors, and thus the principle of gradual information was not fulfilled. At the same time, the expansion of Teledoc slowed down, fixed costs had increased, sponsors had not only supported Teledoc, so the source of revenue were distributed among other Telemedicine companies.

\section{Government intervention}

Facing of many complaints, the control authorities carried out targeted and subject-matter investigations. Based on the authority findings, the government commenced to create additional strict professional and substantial conditions for Teledoc and similar companies. For example, full-time employment of an adequate staff, ongoing reporting and internal regulatory obligations, high information security requirements, standards for consumer protection and service levels. The fulfilment of increased personnel and tangible requirements meant increased expenditures in addition to stagnant revenues, and profitability declined rapidly.

\section{Co-investment}

After the successful Business Angel investment and exit, the management of Teledoc decided to invite a co-investor to make the company profitable again. The investor, who came as a regional venture capital fund, started development with professional portfolio managers, extensive business relationships and a regional approach. After extensive market research and analysis, it revealed that the future lies in the data economy. In Healthcare this meant, that along with "bedside" as well as "webside" should have been a channel for health information and communication. Information of Patients were managed in a health administration system and database, which was introduced in the meantime by the government, which recorded the Patient's medical history and treatment in the System. In addition, individual measuring devices could help a lotespecially in emergency situations. The 
hypochondriac measured his/her heart rate and blood pressure in every 4 hours a day and noted the measurements in a school booklet so that he/she could show his/her Doctor what his/her illness was. Why do you need hypochondria to detect this these days? You have got the smartwatch, the fitness watch, you just must be able to get the data out of it. Not to mention what a goldmine this could be for a pharmaceutical company in clinical research. Recognizing the latter, a lot of smart devices became available for people who registered for free. Which was not free of charge, since the user paid for it with his/her data, but Patients had a common interest in health care for the research.

\section{Legal \& Social obstacles}

Investments were converted to data assets, huge regional and global databases were created, the computing capacity to manage them were developed, and they needed to be managed. The legal obstacle to manage data was primarily a rethinking of data privacy rules. From a data protection point of view, specific health rules have been developed which, on grounds of health interest, as a stand-alone legal basis, had allowed the controller to use the health data, which were special (sensitive) data, in large numbers, by means of machine processing, anonymously for research purposes, or to be transferred, recorded, evaluated, and extracted, even online, in a non- anonymous manner based on the same legal basis.

The other obstacle against innovative data management tools was because Doctors were obviously unwilling to use data, they did not measure at first. It remained Doctors' responsibility to make a diagnosis, and according to their studies, they had to carry out the tests based on measurements under credible and laboratory conditions. Therefore, the Government required in its mandatory training system to introduce new results related to the data economy. Doctors, based on their own experience, realized that these unauthenticated devices could raise suspicions, even if they had not provided certainty. Thus, while maintaining liability rules, modern tools and methods have been integrated into healthcare, a secure and responsible data industry was established in healthcare, which picked up, managed, processed, operated, protected, developed the hardware and software environment, cleaned, analyzed, and researched data, which required enormous computing capacity, automation, and the development of new kinds of cognition and coding innovation. The deep learning machine, a special type of artificial intelligence deployed in several fields, was the right tool for this.

\section{Speed up of implementing innovative technologies}

Accelerated events happened during an unfortunate pandemic. The Doctor's appointment in primary care required the 
use of modern means of communication. Due to the possible and fragmentation of individual clinic and hospital booking systems, it was no longer able to avoid mass waiting rooms. Therefore, there was a need at government level for the use of modern tools and institutional telemedicine. It was not possible to build this immediately, so governments had two options: either involve the Teledoc and Telemedicine services, web doctor applications, management systems available on the market, call center applications. Second option was that government bought such companies and, by regulation, establishes a single Patient journey management system.

\section{AI changed}

\section{the asymmetric information flow}

As the pandemic had passed, the need of immediate digitization made the medical society realized that innovative tools were not against them, and successfully supported their operation. Teledoc became a healthcare customer contact center, using the most advanced artificial intelligence opportunities, and was on the market as a regional provider. The revenues included social security funding, such as care management selected through public procurement and outsourced in this way, whose policies, professional protocols and measurement, key indicators were developed jointly by the service providers with the Social Insurance Funds. Care management via the Patient pathway calculated on the Patient's initiative and input a personalized assessment of when testing, intervention and treatment are expected, taking account the waiting lists available from the hospital databases. The Patient could then decide whether to follow the recommended path or follow the path of his doctor, who may also initiate the optimal determination of the Patient's path in the system.

The efficiency and effectivity of the medical service was also analyzed by using artificial intelligence system on the social security side. In this way the Health Administration, Social Security and Supervising Authority were able to control spending and efficiency, so that the service providers could gain bonus revenues rather than performance limitations in case over performance of key indicators.

Decisions of financing are still not made by Patients, often not by doctors, but by providers and the Funds. However, the monopoly of supply and information asymmetry can be counterbalanced using such innovations by processing accurate and up-to-date information obtained during Patient route management and follow-up. The information thus processed and the Patient's personal feedback on the changed or restored quality of lifestyle (health stock - Gulacsi, 2005) the treatment itself, the quality of the personal and material conditions, the style in which the patient was informed, the Doctor- Patient communication, all allowed for further improvements in Healthcare. 


\section{AI Future - Utopia?}

Innovations of smart computers and data technology improvements changed the law, key players of the Health Market could have been the engine of development, the question was just the timing.

Smart computers \& Law: Computing capacities were available to exploit the clean and uniform databases. After legislation established the special legal basis of controlling and managing medical data, that could be researched anonymously, the use of artificial intelligence (AI) was expanding. The liability for causing damages was still on the Service Provider's behalf, who was responsible for approving smart computer's operation. The company which produced the hardware and software background of smart computers would be the final to pay for the compensations in case of damages. The smart computing companies had to had special insurance for this risk to cover and had to paid contribution to a special Fund. The special Fund Managers would be market supervisors as well, and they would create standards and ethical codes and would watch the market by using independent supervisors.

Social Funds and Patients: Using of innovative Healthtech solutions increased the costs of Funds first. At the same time, Patients were much keen on buying innovative services even if they had to pay extra fee for it, the Patient's Trust in AI sprang up, so the medical innovations and investments improved year on year, the rapid increase and market utilization of the technology gained further innovations, and access for Patients to medical services improved. As a result of increased access to medical services, the Funds had more Patients, and they gained higher income.

Medical Staff: The fear of health workers of losing their jobs by using smart computers and machines did not prove the truth. New jobs were created for the operation, programming, development and testing of smart computers, or machines managed by AI solutions. To teach a computer to be smart needed huge number of qualified professionals and new job functions, new professions had to be educated in Schools as well.

Venture Capital investors ( $\left.V C s^{\prime}\right)$ : Clinical trials to find subjects never had been easy, but after startups tested AI on huge amount of anonymous data to learn from, the medical services and products were easier and faster, and even cheaper got to regulatory admissions. VC investments could afford to take high risks to be guinea pigs in the use of AI in HealthTech Industry and had successful exits. After the market proof of AI services in Health Industry, the risk of investing HealthTech was reduced, so everyone wanted to invest into the "Goldmine".

\section{Predictions and possible future products $\&$ services}

Radiology: In the case of mammogram screenings, two independent medical 
opinions were required at the time of diagnosis. In this resource intensive area, with the introduction of the AI application, the problem of missing medical human resources was almost solved. After many years of clinical tests, one of the two mandatory medical opinions would be replaced by machine processing and pre-screening, the AIbased application achieved and surpassed the processing capacity of a human professional through thousands of analyses. Although it was still a doctor who made the final diagnosis, in the field of imaging diagnostics, the possibility of spreading AI would have been opened (Net1).

Screening test: In shopping centers, the former photo shop booths for ID card photos were replaced by AI rapid screening stations. The patient placed his/her palm in the booth on a diagnostic surface through which he/she examined his/her pulse, heart rate, skin, hair, and nail condition, performed an automatic voice sample analysis, asked a few questions about the patient's complaint or condition, answered questions, and gave quick suggestions as to which general practitioner or specialist to visit with his/her complaint. In return for the charges, the Patient received medical data and suggestions by e-mail or phone, giving him/her the available office contact details of his/her doctor (Gáti, 2020).

Surgery: From remote locations, via a $5 \mathrm{G}$ data transmission channel, minor surgical procedures can be performed using ro- botic arms, which AI continuously analyses and assists, for example by providing hand tremor insurance to the doctor operating through the robotic arms. (see: a 'Banana Operation' in Net2).

Pharma: Companies and authorities, especially Patients, no longer had to fear falsification of medicines after using AI and blockchain technology. Blockchain ensures the control of safe drug pathway data, and AI evaluated of large amounts of data. Pharma companies and also Authorities, Social Funds could track unnecessary prescriptions and purchases, but also they could ensure that counterfeit medicines do not reach the market.

Clinical research: In many cases, AI accelerates research phases or even skips individual steps in the field of individual diseases, the physiological effect of the molecular compositions in the test tube is tested by computer simulation (Callaway, 2020).

Inpatient care: Inpatient care had also undergone a major change, the charts and Patient documentation were no longer kept manually. The nurse recorded the Patient's condition in a voice system, so that it was processed immediately. The following shift staff saw every single medical data that had been recorded. General disinfection of rooms, collection of laundry and garbage was carried out by self-driven robots. AI based system calculated individually the food proportions, based on medical and dietetic recommendations, depending on personal body weight, blood type and daily 
movement, and took care of procurement orders and logistics. Meals were also distributed by self-propelled robots and also logged the leftovers when collecting the dishes and generated a report to the Patient's file (Ráski, 2020, Meskó and Radó, 2020).

Dentistry: At the dentist, a 3D technology device was used to map the Patient's mouth, teeth and previous panoramic Xrays, which allowed the dental technician to customize the new tooth or dentures using an artificial intelligence application. This design was presented to the Patient, who could choose additional shapes, patterns, color codes based on dental plans (CAM) made from his/her own mouth. The approved tooth test (patient's consent) would be sent online, which would also be printed by a third provider's artificial intelligence 3D printer (CAD) and delivered to the dentist. If oral surgery was required or an implant was implanted in the mouth, the oral surgeon was assisted by artificial intelligence on a 3D projector to show how deep he could drill, where to drill exactly when the patient moved in, and where not to drill, where nerves ran (Net3).

\section{References}

Callaway, E. (2020): 'It will change everything': DeepMind's AI makes gigantic leap in solving protein structures. Downloaded: 2021.03.10. Web:

www.nature.com/articles/d41586020-03348-4
Fehér, K., Kökényesi Bartos, A. \& Bártfai, B. (2020): Mesterséges intelligencia avagy Pandora digitális szelencéje. Budapest (HU): BBS-INFO.

Gáti, J. (2020): Nem képtelenség? /Not nonsense?/ HVG, 2020.10.08, p. 50.

Gulácsi, L. (2005): Egészség-gazdaságtan /Health Economics/. Budapest (HU): Medicina

Meskó, B. \& Radó, N. (2019): The Medical Futurist: The technological future of medical specialties. Budapest (HU): Webicina Tanácsadó és Szolgáltató Kft.

Net1. Downloaded: 10.06.2021, Web: www.kheironmed.com

Net2: Tele-surgery performed by a London-based surgeon on a banana fruit in California, using the 5 G commu. Downloaded: 12.06.2021. Web: https://www.youtube.com/watch?v= 5jn8fjLXTiI

Net3: Fájhat a fogunk a robotra, amely segít, ha fáj a fogunk. HVG, 2020.11.02. . Downloaded: 20.11.2020. Web: https://hvg.hu/360/202044_robotde ntista_fajhat_afogunk_ra

Ráski, P. (2020): A szolgáltató robotok gyorsan terjednek /Service robots are spreading rapidly/. Világgazdaság /World Economy/, 52. évf., 206. szám, 2020.10.26., p. 2 Web: https://www.vg.hu/kozelet/2020/10 /gyorsan-terjednek-a-szolgaltatorobotok-2 


\title{
FANTÁZIAKÉPEK AZ UNIVERZUMRÓL \\ - ÜRMÜVÉSZET (SPACE ART)
}

Szerző:

Ujfaludi László (professor emeritus)

Eszterházy Károly Egyetem

A szerző e-mail címe:

ujfaludi.laszlo@gmail.com
Lektorok:

\author{
Mezô Ferenc (PhD) \\ Eszterházy Károly Egyetem \\ Borbélyné Bacsó Viktória (PhD) \\ Medgyessy Ferenc Gimnázium \\ és Mûvészeti Szakgimnázium
}

és további két anonim lektor...

\begin{abstract}
Absztrakt
A modern csillagászattal és az űrkutatással egyidőben új művészeti ág jött létre: az űrművészet (space art). Jelen tanulmány bemutatja az űrművészet történetét, témáit, jellemzőit.
\end{abstract}

Kulcsszavak: űr, mûvészet

Diszciplinák: természettudomány, űrtudomány, képzőművészet

\section{Abstract}

FANTASY PICTURES ABOUT THE UNIVERSE - SPACE ART (SPACE)

Simultaneously with modern astronomy and space exploration, a new branch of art was created: space art. Present study shows on the histroy, themes, characteristics of space art.

Keywords: space, art

Disciplines: natural science, space science, fine arts

Ujfaludi László (2021): Fantáziaképek az Univerzumról - Ürművészet (Space Art) Mesterséges intelligencia - interdiszciplináris folyóirat, III. évf. 2021/1. szám. 19-31. doi: 10.35406/MI.2021.1.19 
„Mivel hosszú időtávon minden civilizáció ki van téve az űrből jövő veszélyeknek, a túlélés érdekében űrutazóvá kell válnia - nem a felfedezés vágyától, vagy valamilyen romantikus hevülettől hajtva, hanem az elképzelhető legpraktikusabb okból: életben maradása érdekében. $\mathrm{Ha}$ hosszú távú túlélésünk a tét, fajunk iránti elemi kötelességünk más világok megismerése."

\section{(Carl Sagan)}

A modernkori csillagászattal és az űrkutatással egyidejűleg létrejött egy új művészeti ág: az űrművészet, angolul space art. Az új művészeti ág alkotásai általában űrkutatási, csillagászati felfedezéseket illusztrálnak (például az újonnan felfedezett extraszoláris bolygók tájképei) és magyarul többnyire „fantáziakép”, angolul „artist's impression" felirattal jelennek meg tudománynépszerūsítő könyvek, folyóiratok, magazinok oldalain. Ennek az új művészeti ágnak külön tagozata van a NASA-nál, ahol a művészek együtt dolgoznak az ûrkutató tudósokkal, mérnökökkel. Feladatuk az űrkutatás népszerűsítése és az új csillagászati felfedezések képi megjelenítése. Az ûrművészet hazánkban még kevésbé honosodott meg, de Nagy-Britanniában és az USA-ban sok múvelője van. A világhálón óriási anyaga van ezeknek a műalkotásoknak és a hozzá kapcsolódó irodalomnak. Az alábbiakban Ujfaludi (2017) alapján kerül áttekintésre a mesterséges intelligencia (MI) kutatást olykor inspiráló, olykor az MI-t használó Space Art témaköre.

\section{Az ürművészet szerepe, jelentősége}

Az ûrmúvészet mûvelői számára a világűr az ihlet forrása. Szemléltető szerepe mellett ösztönzőleg hat az űrkutatásra. Múvészei, legyenek bármely stílusirányzat követői - egy tágabb összefüggésben kiterjesztik a mûvészet társadalmi-kulturális szféráját az űrkutatásra is.

E művészeti ág társadalmi jelentőségét hangsúlyozza egy nemzetközi konferencia felhívása is:

\begin{abstract}
„Az írók és a vizuális művészek a világűr felfedezésével kapcsolatos képzeletbeli forgatókönyveket és képeket alkotnak. Ezek az alkotások a nagyközönség számára ajtót nyitnak az űrkutatás megismerésére. A képzőmûvészek és az írók valójában lefektetik azokat az alapokat, amelyek a jövő ûrtevékenységét érthetővé teszik a nagyközönség számára, ezáltal biztosítják a szükséges politikai támogatást az ûrkutatási programok megvalósításához."

(Call for Papers - International Conference on Space Research, 1993)
\end{abstract}

Roger Malina meghatározása szerint (hivatkozik rá: Ujfaludi, 2017, 156. o., lásd még: Malina, 1991): „Az űrművészet egy, az űrtevékenységre alapozott kortárs művészeti ág, annak elősegítése érdekében.” William Hartmann (hivatkozik rá: Ujfaludy, 2017, 156. o.) az ûrmûvészet négy fontos célkitűzését hangsúlyozza: 
1. A tudományos kutatás ösztönzése.

2. A történelmi jelentőségű űresemények megörökítése.

3. A nemzetközi együttmúködés ösztönzése.

4. Az információk szintézise az univerzumról alkotott elképzelések és az emberuniverzum kapcsolat jobb megalapozása céljából.

Malina (1991, 147. o.) szerint az űrmúvészet fajtái a következők:

1. Mûvészet, amely az űrkutatás melléktermékeiként létrehozott új technikákat, anyagokat vagy érzékszervi tapasztalatokat alkalmaz.

2. Mûvészet, amely kifejezi az űrkutatás során kialakult új pszichológiai tapasztalatokat vagy új filozófiai elképzeléseket.

3. Mûvészet az ûrben, amelyet a földről kell nézni.

4. Az ûrből nézhető művészet a Földön.

5. Az űrben lévő művészet, amelyet az űrben használnak, vagy az űrből nézik.

$\mathrm{Az}$ űrművészet szervezeti formában is működik: nemzetközi szervezete az IAAA (International Association of Astronomical Artists), amely ma már 20 országból több mint százharminc tagot számlál. Meghirdetett programjában - többek között - a következőket olvashatjuk: „Az IAAA a világon egyedüli testülete azon mûvészeknek, akik a világûr képeinek kötelezték el magukat. (...) Ezeknek a művészeknek a science fiction és a fantasy művészeitől eltérően (akikkel egyébként gyakran összetévesztik őket) minden müalkotása a kutatási eredmények és a tudomány szilárd talaján áll. Kifejezési eszkö- zeik a festészet, a grafika, a szobrászat, az üvegművészet és a számítógép. Céljuk a galaxisok, csillagok, bolygók és holdak bemutatása bárhol az Univerzumban, ahová a képzelet eljuthat, de a kamera (még) nem."

\section{Rövid történeti áttekintés}

Jóval az űrkutatás kezdete előtt elkezdődött a világűr „meghódítása” - az írók és a képzőművészek által. A teljesség igénye nélkül álljon itt néhány példa.

Verne Gyula (1865) Utazás a Holdra (eredeti francia cím: De la Terre à la Lune, trajet direct en 97 heures 20 minutes, ford: Utazás a Holdba: közvetlen út 97 óra és 20 perc alatt) című regényének utasai egy Floridában felállított hatalmas ágyúból kilőtt ágyúgolyó belsejében indulnak útnak és 97 óra alatt érnek a Holdra. A regény olyan szuggesztív stílusban íródott, hogy sokan igaz történetnek vélték. A Hold felszínének leírása meglepő egyezést mutat az Apollóűrhajók legénységének beszámolóival. A regény illusztrációi (Emile Bayard és A. de Neuvill munkái) az első olyan mûvészi ábrázolások, amely szigorúan tudományos tényeken alapultak. Verne regénye alapján 1902-ben Georges Mélies megalkotta az első tudományos-fantasztikus filmet Utazás a Holdra címmel.

A XIX. század második felében James Nasmyth és James Carpenter (1874) egy ma már klasszikusnak tekintett tanulmányt írt The Moon (A Hold, eredeti teljes cím: The Moon: Considered as a Planet, a World, and a Satellite) címmel. A nagyméretű, gazdagon illusztrált múben szá- 
mos táblakép volt, amelyek a távcsöves megfigyelések alapján készült gipszmodellek fényképeivel mutatták be a Hold egyes tájait.

A századforduló táján sok űrművészeti alkotással illusztrált népszerű csillagászati könyv jelent meg. Ezek legnevesebb illusztrátora Lucien Rudaux (1874-1947) volt, aki csillagász és képzőművész volt egy személyben. Számos könyvet írt és illusztrált; még az 1974-ben újra kiadott Larousse Encyclopedia of Astronomy is az ő ábráival jelent meg. További neves ûrművészek a 20. sz. első felében: Chesley Bonestell, Ludek Pesek és David A. Hardy. Tevékenységük néhány figyelemreméltó eredménye: több űrkutatási eseményt előre jeleztek, sokat tettek azért, hogy az ûrkutatás felkeltse az emberek érdeklődését és segítették a tudósokat és mérnököket eredményeik vizuális megjelenítésében és népszerüsítésében.

Az 1950-es években az űrkutatás beindulásának hatására az űrművészet új lendületet kapott. A magazinok és az ûrkutatással kapcsolatos könyvek illusztrációi nagy hatással voltak a közvéleményre bizonyságát adták annak, hogy az ûrkutatás már nem a fantasztikum világa, hanem a tudomány és a technika által elérhető cél.

A Mars-kutatás robot-járművei és a Naprendszer távoli vidékeit feltérképező űrszondák egyre tökéletesebb képet adnak a bolygókról. Az ûrművészet megváltozott szerepéről Ron Miller (2014) a következőket írja: „A modern űrmûvészet művelőinek könnyebb is, nehezebb is a dolga, mint elődeiknek. A Naprendszer bolygói- ról az utóbbi évtizedekben több felfedezés született, mint a csillagászat teljes előző, több ezer éves időszakában. A kortárs múvészeknek jóval több tényanyag áll rendelkezésére; ez a bőség azonban egyúttal korlátozó tényező is. Ma már pontosan tudjuk, milyen a Mars felszíne, sokkal kisebb a múvész szabadsága az ábrázolásban. A képeken az „artist's impression” (,a művész elképzelése”, vagy a magyar „fantáziakép”) felirat ma már nem jelentheti csupán a képzelőerő alkotását."

Az IAAA szervezet kiáltványa történelmi analógiát jelez a korai amerikai múvészet és az űrművészet között: „A 18. és 19. sz.-ban a telepesek eljutottak a meghódított területek határvidékéig és képeket küldtek az új földekrôl. Ezek az alkotások ösztönzőleg hatottak a nagy nemzeti parkok (Yellowstone, Yosemite) létrehozásához". A felfedezetlen végvidékek azonban hamar eltûntek és a művészet és a felfedezések közötti kapcsolat megszakadt. Az űrművészet révén ez a kapcsolat - egy egészen más területen - újjászületik.

\section{A modern űrművészet néhány jellegzetessége}

A legismertebb jelenlegi űrművészek (Michael Carroll, Lynette Cook, Mark Garlick, William K. Hartmann, Ron Miller, Pat Rawlings) alkotásai gyakran jelennek meg tudományos magazinokban és az új felfedezéseket bemutató kiadványokban. Külön említést érdemel a nálunk is ismert Dana Berry (2005), akinek tetszetősen illusztrált könyve „Rendhagyó galaktikus 
útikalauz" címmel magyarul is megjelent (Berry a könyv szerzője és illusztrátora).

Az űrművészet alkotói minden korábbinál nagyobb mértékben támaszkodnak a tudomány eredményeire. A tudomány, mint a művészet ihlető forrása már a reneszánsz idején megjelent és a modern korban ez a tendencia tovább erôsödött.

A tudomány-művészet szimbiózisának legmarkánsabb reneszánszkori alakja Leonardo da Vinci, az „uomo universale” példaképe, aki a mûvészetben, a technikai találmányok és a tudományos felismerések területén is jelentős életművet hagyott ránk. Verne Gyula regényei a tudományos eredményekre alapozott kalandregények mintapéldái. A neves amerikai költő, Walt Whitman egyik verseskötetének (Fûszálak) előszavában a tudományt nevezi a költészet legfőbb ihlető forrásának. A neves francia író Émile Zola egyik esszéjében arról számol be, hogy társadalmi tényfeltáró regényei írásakor egy neves orvosprofesszor tudományos módszertani elveit követi. Victor Vasarely (Vásárhelyi Győző), az op-art művészet vezéralakja visszaemlékezéseiben így ír: „Ezekben a döntő fontosságú években (az 1930-as, 40-es évek-ről van szó) csak úgy falom a különféle könyveket a relativitáselméletről, a hullámmechanikáról, a kibernetikáról, az asztrofizikáról. A tiszta fizika akkor, mint a költészet új forrása ragyogott fel szemem előtt. A hagyományos táj eltűnik, bizonyosság és bizonytalanság váltakoznak. A hullámok hátán, vonzó vagy taszító mezőkön rohanok előre, hol az atomok, hol a galaxisok felé" (idézi: Ujfaludi, 2017, 158. o.).
Valószínű, hogy Vasarely és a többi idézett művész nem tudta teljes mélységében magáévá tenni a tudomány eredményeit, de az új felismerések, az új szemléletmód, új ablakot nyitottak előttük a világra. Az Amerikában élt neves magyar képzőművész, Kepes György teljes életművét a tudomány és a művészet együttműködésének jegyében alkotta. Magyarul is megjelent könyvét: „A világ új képe a művészetben és a tudományban”, ennek a felfogásnak szellemében írta (Kepes, 1979).

Az új művészeti ág egyik klasszikusa, Chesley Bonestell szerint az űrművészet művelője az alábbi követelményeknek kell, hogy megfeleljen: „Tudnia kell érzékeltetni, hogy a fény színe, az ég színe, a tájképi környezet miért jelenik meg úgy, ahogyan ábrázolja és a körülmények drasztikus változása hogyan változtatja meg a táj képét. Továbbá megfelelő természet-tudományos ismeretekkel kell rendelkeznie: időjárási és geológiai ismeretekkel a Föld, és csillagászati ismeretekkel az ég jelenségeinek megértéséhez" (idézi: Ujfaludi, 2017, 158. o.). Az űrművész legfőbb szövetségesei a geológusok, az űrkutatók, a csillagászok, az asztrofizikusok és a tudományos szakírók. Legfontosabb eszközeik: a hagyományos festészeti eszközök, a számítógép, az űrfotók, asztrofotók és a kutató ûrszondák információi.

\section{Az ürmüvészet helye a modern müvészetben}

Egyre nő azoknak a múvészeknek száma, akik tehetségüket az űrművészetnek 
szentelik. A jelenkori művészet fó áramlatai csak lassan kezdik elismerni ezt az új művészeti ágat; nagyon sokan - a sci-fi irodalomhoz hasonlóan - ezt sem tekintik „komoly” mûvészetnek. Ezért ezek az alkotások leginkább tudományos-technikai múzeumokban és planetáriumokban lelhetők fel. A közelmúltban azonban már jelentős múzeumok és mûvészeti intézmények is növekvő figyelmet fordítanak a világűrrel kapcsolatos alkotásoknak, így az űrművészet végül elnyeri méltó helyét a modern múvészetek sorában.

Az alkotói módszerről írja Ron Miller (2014) Space Art című könyvében (idézi: Ujfaludi, 2017, 159. o.).: „A művész célja a valóság megfigyelése, személyes impresszió kialakítása és azoknak a módszereknek a kifejlesztése, amelyekkel ezt az impressziót képes kifejezni." Ez a meghatározás a teljes jelenkori művészetre is érvényesnek tekinthető, van azonban egy lényeges különbség az ûrművészet és a többi múvészeti ág között. A modern mûvészet legtöbb irányzatánál az alkotók szabadsága szinte korlátlan; az űrmüvészetben ez a szabadság kétféleképpen is korlátozott:

1) Bizonyos képi elemeket valósághűen kell ábrázolni (például ismert csillagképeket, bolygók és más égitestek fotókról ismert arculatát); ezekhez járulhatnak fantázia-elemek, például egy óriásbolygó holdjának elképzelt tájképe. A valósághoz való hűség bizonyos esetekben nem is teljesülhet maradéktalanul. Például olyan exobolygók tájképeinél, ahol az ûrszondák észlelési adataiból csak annyi tudható, hogy a bolygónak hidroszférája és légköre, esetleg feltételezhetően szilárd kérge is van, a tájképi elemek és a feltételezett életformák ábrázolása tekintetében szinte korlátok nélkül szárnyalhat az alkotói fantázia.

2) Az űrművészet alkotásainak jelentős része könyvek és magazinok illusztrációja, következésképp az alkotó eleget kell, hogy tegyen a megrendelő bizonyos elvárásainak. Az ilyen esetekben az alkotó és a megrendelő között interaktív kapcsolat van és a végleges alkotás a felek közötti konszenzus eredménye. Ez olyan jellegzetesség, amely a modern művészet más ágazatainál szinte ismeretlen (kivétel talán az iparművészet és a reklámgrafika). A képzőművészet korábbi időszakaiban (a középkori egyházi festészettől egészen a 20. századig) viszont ez az interakció alapvető követelmény volt.

Németh Lajos (1999) „A művészet sorsfordulója" című gondolatgazdag könyvében azt írja, hogy „,igazi művészet csak totalitás-élményből fakadhat" (idézi: Ujfaludi, 2017, 159. o.), ilyen totalitás-élményt nyújtott a kereszténység, innen származtathatók a középkor és a reneszánsz remekművei. A 19. sz. végére ez a teljességélmény felbomlott, a „darabokra szakadt” világ élménye már csak partikuláris megoldásokat kínált a mûvészeteknek, ezek követhetők nyomon az európai avantgárd sokféle irányzatában.

$\mathrm{Az}$ űrkutatás, tágabb értelemben a csillagászat és a kozmológia egy új totalitás-élményt kínál a mûvészetnek; ennek mottója: „Hazánk az Univerzum”, forrása pedig annak távlati igénye, hogy fennmaradásunk 
érdekében új hazát kell, hogy találjunk gondoljunk a tanulmány elején olvasható Carl Sagan idézetre).

Az űrművészet alkotásai lényegében ennek a kozmikus dimenziójú totalitás-élménynek a művészi visszatükröződései.

Arthur Woods, esztéta és alkotó művész írja: „Az utóbbi évtizedekben az űrmüvészet legalább annyit tett az űrprogram sikeréért, mint a műszaki haladás. Ahogy a korai amerikai művészek megmutatták a közönségnek a még ismeretlen Nyugat tájait, ezzel feltárva a felfedezés és a terjeszkedés lehetőségeit, úgy az űrművészet alkotói megmutatják, milyen látványt nyújt egy láthatatlan bolygó, hold, vagy a galaxis egy távoli vidéke, ha majd személyesen is ott lehetünk" (idézi: Ujfaludi, 2017, 160. o.). Kétségtelen, hogy számos űrkutató és mérnök kapott indíttatást sci-fi regényekből, vagy filmekből az űrkutatás elmúlt 50 éve alatt. Az űrművészek pedig segítették ezeket a szakembereket programjaik szemléletessé tételében és abban, hogy formát adtak újonnan kifejlesztett eszközeiknek. Emellett kapcsolatot teremtenek a szakterület és a közönség között; az adófizetők közül sokan azért álltak az űrprogram lelkes támogatói közé, mert olvasták a képekkel illusztrált magazinokat és népszerū tudományos könyveket.

\section{Rendezvények, programok, érdekes produkciók}

A zürichi Museum für Gestaltung 20012002-ben kiállítást rendezett az asztronauták mindennapi (súlytalanságban töltött) életérôl. A műalkotásokat képzőművészek, iparművészek és építészek készítették.

A londoni Tate Gallery (a klasszikus és modern angol festészet és szobrászat fellegvára) 2003-ban nagyszabású kiállítássorozatot rendezett. A Space Art és Space Architecture című kiállításon régebbi és új műalkotásokat és űrépítmények (űrállomások, űrkolóniák) modelljeit mutatták be. Kísérő rendezvény volt egy verseny, amelyen fiatal alkotók - egyetemi, főiskolai hallgatók - mutatták be ûrépítmény-modelljeiket. Egyes modellek pontos leírása és összerakható elemeinek rajza még most is megtalálható a Tate Gallery honlapján.

Újabb irányzat az előadó- és képzőművészet a zéró gravitáció (súlytalanság) állapotában. Ennek első produkciója: a MIR űrállomáson (a Nemzetközi Ürállomás elődje) két űrhajós táncos produkciót mutatott be 1993-ban; a súlytalanság állapotában.

Az ún. parabola-pályás repülések is teret adnak a Space Art egyes programjainak. Ezek egy utasszállító repülőgépen (Boeing KL 135 Turbo-Jet) végzett kísérleti repülések, amelyek egy-egy alkalommal 2040 parabola-manővert hajtanak végre, 2025 másodperces zuhanórepülésekkel, miközben előáll a súlytalanság állapota. Az ilyen repülést „microgravity environment"-nek is nevezik. Kitson Dubois francia koreográfus egy sorozat parabolapályás repülésen vett részt 1990 és 1999 között. Tapasztalatait később egy modern balett jeleneteiben kamatoztatta. Frank Pietronigro az első művész volt, aki a levegőben 
lebegő vásznakon vizsgálta a súlytalanság hatását képek festése közben; kísérleteit a NASA támogatásával végezte.

Az ûrkutatás sokrétű tudományos és művészeti megközelítésére találunk sok példát Mező és Mező (2020) művében is.

\section{Képgaléria}

Az űrművészetnek óriási képanyaga található a világhálón. Ebből a bőséges anyagból választottunk ki néhány alkotást az alábbi képgalériához. A képek a Naprendszerből kiindulva egyre távolabbi helyszíneket idéznek, a legtávolabbi objektum egy 272 millió fényév távolságban lévő egymással ütköző galaxis-kettős. A képek többsége a NASA archívumából származik és elképzelt tájakat mutat. Az extraszoláris bolygókról általában csak néhány spektroszkópiai jellegű információnk van - például a bolygónak van légköre, szilárd kőzet a felszíne és folyékony víz is található rajta. Minden további részlet (élőlények, űrvárosok, stb.) a fantázia szüleménye.

Az 1. ábra egy képzeletbeli Mars-kolóniát ábrázol. A Mars „meghódítása” az űrkutatás nem titkolt, legközelebbi célja. A merész vállalkozóknak azonban sok problémával kell megbirkózniuk. Ezek közül csak néhány: kedvezőtlen légköri adottságok és nagy a hőingadozás (emiatt viselnek a képen szkafandert az ûrhajósok); erős a kozmikus sugárzás, ami ellen hatékony védelem kell; gyakran nagy porviharok vannak. Víz a felszín közelében csak jég és igen ritka vízgőz állapotban van jelen. Folyékony víz csak nehezen hozzáférhető helyeken: vastag jégrétegek alatt található, hasonlóan az Antarktisz vízzárványaihoz. A legmerészebb elképzelések szerint azonban lehetségesnek tartanak egyfajta „terraformálást”, vagyis a földihez hasonló körülmények megteremtését szomszéd bolygónkon.

\section{1. ábra: Egy Mars-kolónia lakói munkában} (Bossinas, 1989)

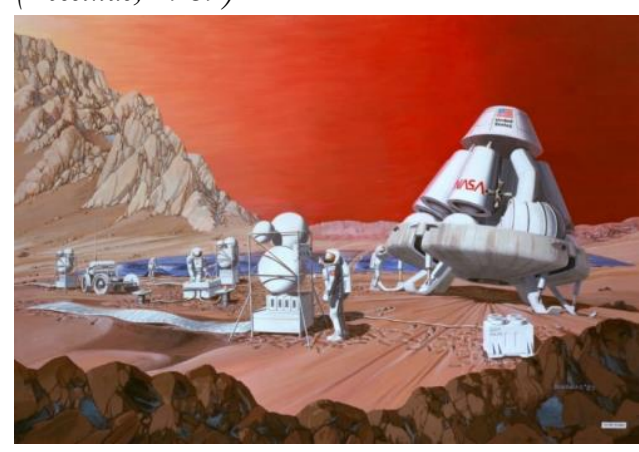

A 2. ábrán látható Európa a négy legnagyobb Jupiter-hold (az ún. Galilei-holdak) egyike, felszínét jégtakaró borítja. A jégréteg folyamatos folytonos átrendeződése repedéseket, jégtorlaszokat idéz elő; ezeket látjuk a képen. Az égbolton a Jupiter hatalmas gömbje fénylik, előtte a legközelebbi Galilei-hold, a vulkanikus Io látható. Nemrég szenzációt keltő hír röppent fel: a Galileo-műhold 1997-es észleléseinek újraértékelésekor megállapították, hogy a jégtakaró egyes helyein vízgőzkitörések (water vapour plumes) láthatók. Tévesen először gejzírekről szólt a hír. Gejzírek két helyen is vannak a külső 
bolygók holdjain: a Szaturnusz holdján, az Enceladuson, és a Neptunusz holdján, a Tritonon.

2. ábra: A Jupiter és az Io az Európáról (V an Ravenswaay, D., 2013)

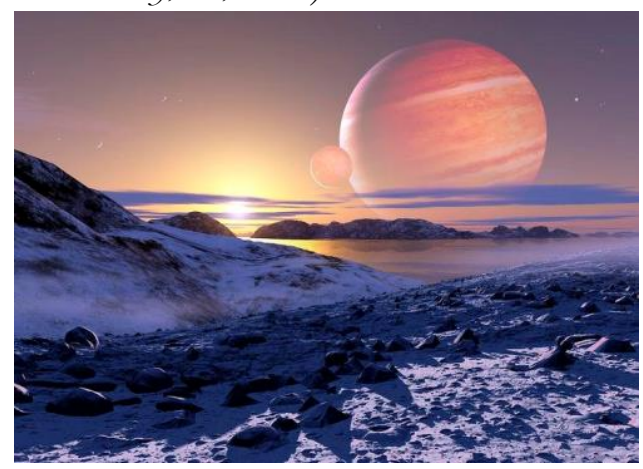

Bruneton (2006) „Rama” című rövidfilmjében (3. ábra) egy gigantikus űrkolónia látható, s a videó megtekintése során egy virtuális utazást tehetünk az űrkolónia belsejébe. A videó érdekessége, hogy kísérő zenéje Allegri Miserere című kórusművének stilizált változata. A kórus kottáját évszázadokig féltve őrizték a Vatikánban, míg 1770-ben a gyermek Mozart egyszeri hallás után pontosan lekottázta, innen vált általánosan ismertté. A videót Arthur Clarke (1973) „Randevú a Rámával’ (Rendezvous With Rama) című műve ihlette, amelyben a Rama egy hatalmas, henger alakú, forgásával mesterséges gravitációt előidézni képes idegen űrjármű.

A 4. ábra a Gliese 876 változó vörös törpe csillag egyik bolygójához kapcsolódik. A csillag körül a Merkurnál is kö- zelebbi pályán kering a Földnél jóval nagyobb tömegű d-jelű bolygó, amelyen a csillaga által keltett ún. gravitációs árapály által keltett intenzív vulkanizmus működik. Ehhez járul a csillag erôs mágneses aktivitása által okozott gázkitörések sora. A bolygónak a 4. ábra jobb felső sarkában látható holdjáról épp most fújja le a légkört a csillagról érkező erős részecskeáramlás (a drámai kép jelenségeinek többsége a fantázia szüleménye).

3. ábra: Képkocka a 'Rama' címü rövidfilmböl (Bruneton, 2006)

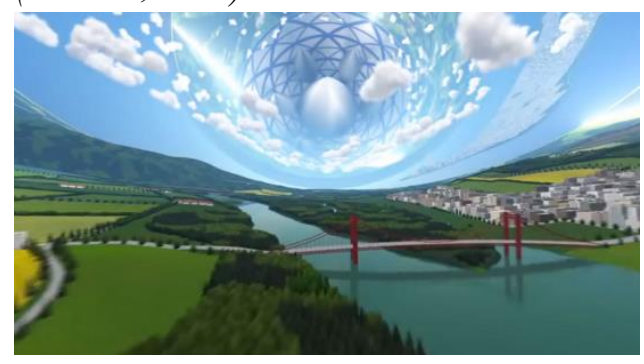

4. ábra: Veszélyes napkelte a 15 fényév távolságra lévö Gliese 876 d bolygón (Nielsen, s.a.)

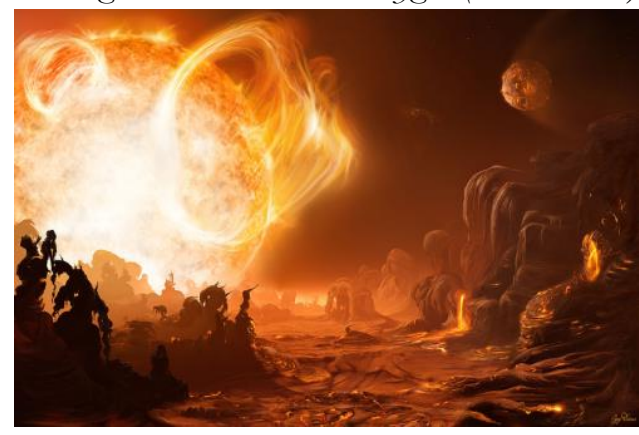


Az 5. ábra tájkép a Gliese-667 Cc bolygóról. Ez a bolygó egy hármas csillagrendszer egyik tagja (vörös törpe, az 5. ábrán felhővel takarva) körül kering.

5. ábra: Hármas csillagrendszer körül keringő távoli extraszoláris bolygó (23,6 fényév távolságra). Szerzoó: Calçada, L./ESO (2012)

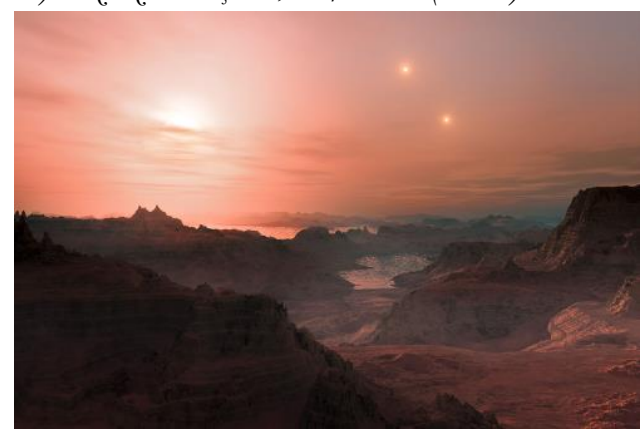

A 6. ábrán lát-ható (fantázia-)táj a Trappist-1 sorrendben 4. bolygójának része (a bolygórendszert a közelmúltban a Spitzer infravörös űrteleszkóp fedezte fel).

6. ábra: Tájkép a Trappist-1f bolygón (39 fényév távolságra). Szerzoo: Pyle/NASA/JPLCaltech, 2017.

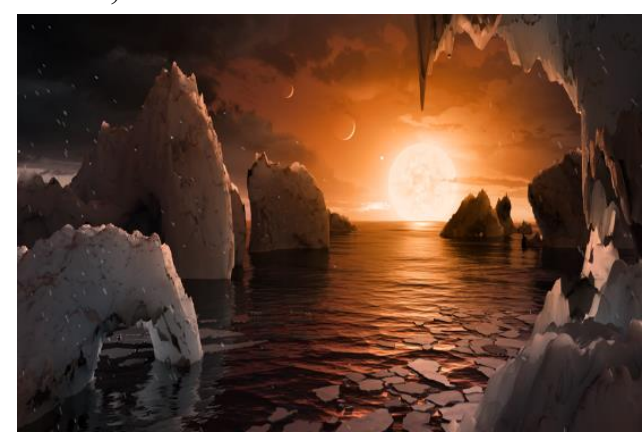

A Trappist-1 vörös törpecsillag, a Naptól 39 fényév távolságra. Körülötte hét bolygó kering, közülük három (az e, f, g jelűek) a lakható zónában vannak. A vörös törpe bolygói igen közel keringenek csillagukhoz, a legtávolabbi is jóval közelebb van hozzá, mint a Nap-Merkúr távolság. Míg a Nap felületi hőmérséklete 6000 fok, a vörös törpék hőmérséklete csak 3000 fok körül van, ezért hozzájuk jóval közelebb van a lakható (0 és 100 fok közötti) zóna, mint a Nap-típusú csillagoknál.

A 7. ábrán látható fantáziakép a fekete lyukak katasztrofális romboló hatását mutatja be. Ezek közelében olyan erôs a gravitációs tér, hogy a szomszédos égitesteket (csillagokat és bolygókat) először szétszakítja, majd elnyeli. Szerencsére Földünket nem fenyegeti ilyen veszély: a legközelebbi fekete lyuk 1000 fényév távolságra van tőlünk.

A 8. ábra egy, a Tejút pereméhez közeli exobolygó elképzelt tájképe, mely égboltjának jelentős részét (az elképzelt közelség miatt) egy gömbhalmaz uralja. A gömb-

7. ábra: Ha a Föld találkozna egy fekete lyukkal (a legközzelebbi 1000 fényév távolságra). Szerző: Kornmesser/ESO, s.a.)

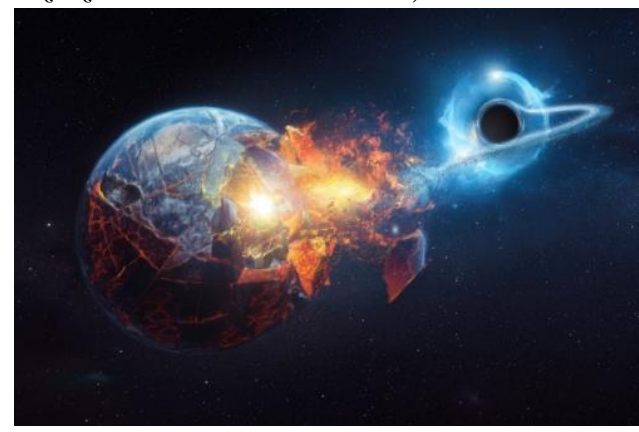


halmazokban a csillagok igen közel vannak egymáshoz (akár 100-szor közelebb, mint a galaxisok többségében). Emiatt a csillagok közötti tömegvonzás igen erős, ami egyrészt igen stabillá teszi ezeket a csillagtársulásokat, másrészt ez az oka gömbszimmetrikus elrendezésüknek. Galaxisunk, a Tejút tágabb környezetében (az ún. „halo”-ban) 138 gömbhalmazt ismerünk.

\section{8. ábra: Tájkép egy gömbhalmazhoz közeli} bolygón (a legközelebbi gömbhalmaz. 5500 fényév távolságra). Szerzọ:: Olsen, 1999

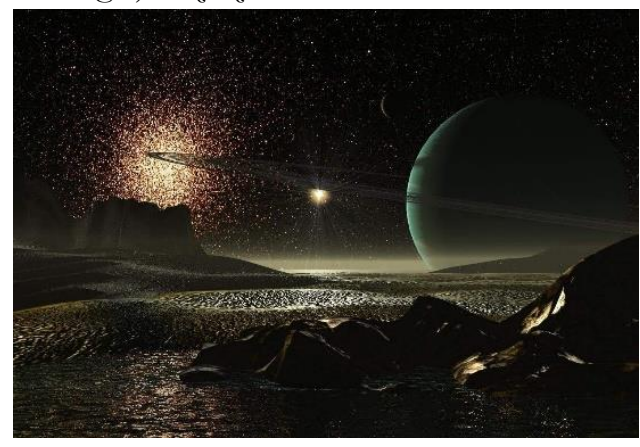

A 9. ábra egy (fiktív) exobolygó pereméről megfigyelt két kölcsönhatásban lévő spirálgalaxist mutat. Az itt látható kettôs az NGC 7752-7753 tőlünk 272 millió fényév távolságra van. A Hubble Ürteleszkóp számos kölcsönhatásban lévő galaxispárt fényképezett le. Az egymás közelébe sodródott galaxisok eleinte nagy mennyiségű anyagot (csillagokat és csillagközi gázt) szívnak el egymástól, majd végül a két galaxis egyesül; feltételezés szerint így jönnek létre a szabálytalan (irreguláris) galaxisok. Hasonló folyamat játszódik le a távoli jövőben a jelenleg nagy sebességgel egymás felé száguldó Tejút és az Andromeda-galaxis esetén.

\section{Epilógus}

A fent idézett néhány példa jelzi, hogy az űrművészetnél is felbukkan a modern múvészet többi irányzatára jellemző „,kísérleti művészet”, az új kifejezési formák keresése.

9. ábra: Extraszoláris bolygó pereme, az. égbolton kölcsönható galaxisok. Forrás: Net1

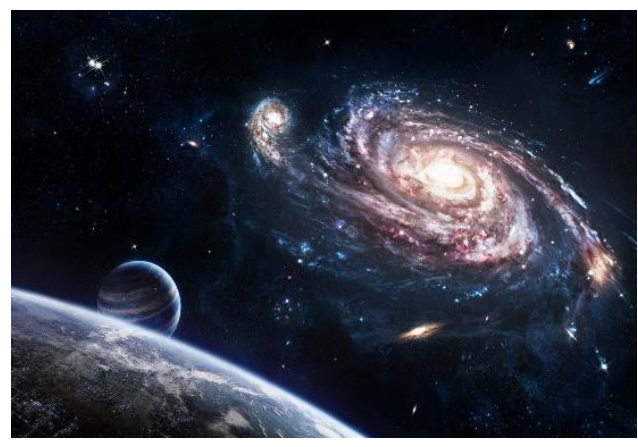

Az űrművészet fő áramlata azonban azt a törekvést próbálja megvalósítani, amely Arthur Woods szép és emlékezetes megfogalmazásában így hangzik: „A kozmosz szépségétől és csodáitól ösztönözve az ûrmûvészet alkotói új művészeti formákat és technikákat dolgoznak ki, előkészítve az emberek kirajzását ebbe az új környezetbe. A múvészeknek ez az új generációja azon munkálkodik, hogy a társadalmat felkészítse a legnagyobb felfedező utazásra, amit az ember valaha is megtett" (idézi: Ujfaludi, 2017, 160. o.). 


\section{Irodalom}

Berry, D. (2005): Rendhagyó galaktikus útikalauz: Scolar Kiadó, Budapest

Bossinas, L. (1989): Mars Mission (paintings). Letöltés: 2021.03.10. Web: https://upload.wikimedia.org/wikiped ia/commons/f/f1/Mars_mission.jpg

Bruneton, E. (2006): Rama (videofilm).

Letöltés: 2021.03.10. Web: https:/ /youtu.be/zBIQCm54dfY

Calçada, L. (ESO) (2012): Gliese 667 Cc sunset. Letöltés: 2021.03.10. Web: https://en.wikipedia.org/wiki/Gliese_ 667_Cc\#/media/File:Gliese_667_Cc_ sunset.jpg

Clarke, A.C. (1973): Rendezvous With Rama. London (GB): Gollancz

Di Fate, V. (1990): Saturn from Iapetus (funérra festett akril festmény). Letöltés: 2021.03.10. Web: https:/ /www.vincentdifate.com/artwo rks/saturn-from-iapetus1990\#featured

Guidice, R. (1970): Cím nélküll. Letöltés: 2021.03.10. Web: http://rickguidice.com/images/753_ Dc13_rev.jpg

Kepes Gy. (1979): A világ új képe a müvészetben és a tudományban. Corvina Kiadó, Budapest.

Kornmesser, M. (ESO)(s.a.): Black Hole Destroying The Earth. Letöltés:

2021.03.10. Web:

https:/ / newatlas.com/gallery-spaceart/51399/

Malina, R. (1991): In Defense of Space Art: The Role of the Artist in Space Exploration. International Astronomical
Union Colloquium. 17. 145. doi: 10.1017/S0252921100003894

Mező F. és Mező K. (2020). Interdiszciplináris asszociációk A földön kívüli életfeltételek megteremtése témával kapcsolatban. OxIPO - interdiszciplináris tudományos folyóirat, 2020/4, 9-21. doi: 10.35405/OXIPO.2020.4.9

Miller, R. (2014): The Art of Space: The History of Space Art, from the Earliest $V$ isions to the Graphics of the Modern Era Hardcover. London (Gb): Zenith Press

Nasmyth, J. \& Carpenter, J. (1874): The Moon: Considered as a Planet, a World, and a Satellite. London (GB): John Murray

Net1. Letöltés: 2021.03.10. Web: http:// eskipaper.com/images/spacegalaxy-art-1.jpg

Németh, L. (1999): A müvészet sorsfordulója. Ciceró Kiadó, Budapest.

Nielsen, I. (s.a.): Gate to Nowhere. Letöltés: 2021.03.10. Web:

https://apod.nasa.gov/apod/ap08052 1.html

Olsen, R.W. (1999): Cím nélküll. Letöltés: 2021.03.10. Web: https://photos.smugmug.com/Space Art/Space-Art/iPVVpqNM/2/ba8f30d7/XL/om_cen 2-XL.jpg Pyle, T. (NASA/JPL-Caltech) (2017): Surface of TRAPPIST-1f. Letöltés: 2021.03.10. Web: https://www.nasa.gov/sites/default/f iles/thumbnails/image/1_main_pia21 423-png.png

Ujfaludi L. (2017): Ürművészet.

Fantáziaképek az Univerzumról. 
Természet világa, 148. évf. 4. sz., 2017.április 156-160.

Van Ravenswaay, D. (2013): A Jupiter az. Európáról. Letöltés: 2021.03.10. Web: https://s-media-cache- ak0.pinimg.com/736x/aa/2e/c9/aa2e c9f02a7279d9555f1348bbe1e5f9.jpg

Verne, J. (1865): De la Terre à la Lune, trajet direct en 97 heures 20 minutes. Paris (Fr): Pierre-Jules Hetzel. 


\section{PRELIMINARY OBSERVATIONS ON AI REGULATION}

\author{
Szerző: \\ Simó Ferenc Zoltán (Dr. Jur.) \\ Debreceni Egyetem
}

A szerző e-mail címe:

simofredz@gmail.com
Lektorok:

Mező Ferenc (PhD)

Eszterházy Károly Egyetem

Borbélyné Bacsó Viktória (PhD)

Medgyessy Ferenc Gimnázium

és Mûvészeti Szakgimnázium

és további két anonim lektor...

\section{Absztrakt \\ ELŐZETES ÉSZREVÉTELEK A MESTERSÉGES INTELLIGENCIA MI) $S Z A B A L Y Y Z A ́ S A R O ́ L$}

Kétség sincs afelől, hogy a technológiai fejlődés megállíthatatlan és afelől sem, hogy a jogalkotók sem tudnak teljes mértékben lépést tartani vele. Azonban mégis szükség van az új technológiák szabályozására és szabályozásuk revíziójára időről időre. Habár, a vizsgálatunk tárgyai a megvalósulás módozati, illetve az eltérő szabályozás lehetősége, amely a normabeli, kulturális/nemzeti különbségeknek/sajátosságoknak és ezek kombinációjának köszönhető.

Kulcsszavak: szabályzás, jog, irányítás, mesterséges intelligencia,

Diszciplínák: jogtudomány, IT, EU tanulmányok

\section{Abstract}

There is no doubt about the fact that the technological progress is unstoppable and not even the law makers can keep up with it wholeheartedly. Still, novel technologies need to be regulated and their regulation aches for revision time after time. Although, the subject of this study is the way how it is to be done, and the possible regulatory differences, owing to different norms in combination with national/cultural differences

Keywords: regulation, law, governance, Artificial Intelligence

Disciplines: Jurisprudence, IT, EU Studies

Simó Ferenc Zoltán (2021): Preliminary Observations on AI Regulation. Mesterséges intelligencia - interdiszciplináris folyóirat, III. évf. 2021/1. szám. 33-59. doi: 10.35406/MI.2021.1.33 
"It is change, continuing change, inevitable change that is the dominant factor in society today. No sensible decision can be made any longer without taking into account not only the world as it is, but the world as it will be...."

(Isaac Asimov)

The distribution and application of new technologies is frequently accompanied with ambiguities as to their long-term (un)intended or unwelcomed impacts, concerning almost all walks of life, including, for instance, law/regulation, privacy or environmental protection and so on. New technologies also pose questions (and a considerable amount of concerns) about the restrictions of the law as the line between injurious/damaging and positive effects is regularly difficult to draw, and even to find. Still, I assume that the necessity to regulate and to revise regulations time after time cannot be questioned, although the way how to do it may differ, due to different norms in combination with cultural differences between countries seem to result in variances in the (practical) enactment, understanding and enforcement, not to mention compliance as well (Compliance is one of the major topics in the European Union but this dissertation will not go into this topic wholeheartedly, but to scratch its surface is unavoidable). It is even more burdensome for scholars to agree on an issue, such as regulation. Ronald Leenes, for instance, argues that "[a]nytime a new technology materializes, or when innovators and entrepreneurs come up with a novel way of doing business, calls for regulatory changes can be heard. These voices do not only come from students and Ph.D. students, who by definition still have a lot to learn, but also from developers, engineers, policymakers, and the odd scientist, who may quickly arrive at the conclusion that there is a regulatory disconnect in need of fixing (Brownsword, 2008). Many people seem to suffer from the Flawed Law Syndrome: the (immediate) urge to call law or regulation outdated or flawed (disconnected) and the desire to fix the problems by addressing the law, rather than using other ways to mend the assumed gaps ('Legal Solutionism)" (Leenes, 2019, 5-6. p.).

Obviously, the "other side", the industry may also complain that the law required to be reformed. Industry typically brings forward two claims concerning the regulatory framework in their own field: first of all, that they are disproportionately constrained and, secondly that the rules are vague or imprecise, two of my primary aims are, first, to discuss why this vagueness may happen, and second, is to relate this ambiguity and elusiveness to novel technologies, such as drones, biometric systems, AI, and so on with the intention to find some practical solutions.

The reaction to make complaints about the regulatory framework seems to be the automatic reaction (of any sides) every time a novel technology appears, rather than exploring the actual state of the art with regard to the technology and the law 
(For instance, in the case of robotics, one can learn more info by: Leenes \& others, 2017). Some scholars argue that the next on the agenda might be robotics, probably, right after, drones, ICT, biometrics, biotechnology, nanotechnologies, and neuroscience-related technologies, since robotics can be considered as a next major broad field of technological improvement that necessitates the attention of regulators (For example: Leenes \& others, 2017). As a matter of fact, the European Parliament, Committee on Legal Affairs drafted its first report with recommendations to the Commission on Civil Law Rules on Robotics on 27 January 2017 /2015/ 2103(INL). What can connect all these forms together is a sense that the technological products demonstrate some level of autonomy in their functioning (The question of autonomy is one of the major motivators of debates concerning AI, robots, or drones as well.), which gives an innovative edge to the interaction between humans and technology; and it is this characteristic, for instance, that makes robotics as a relevant field for regulators and regulation scholars to examine.

Technology and regulation are frequently seen and portrayed as opponents or oppositions. Since technology often symbolizes different kinds of markets, enterprises, and progression, while regulation embodies government, bureaucracy (and its apparatuses), and restrictions to growth and development. Jonathan B. Wiener argues that " $[\mathrm{t}]$ he modern regulatory era, beginning in the 1960 s, has regularly pitted calls to restrain technological risk through regulation against the competing concern that regulation could unduly hobble new technology and progress.

In the 1970s that debate focused on technologies such as nuclear power, supersonic transport, and food additives. Today the debate continues as fears of technologies such as electromagnetic fields, greenhouse gas emissions, and genetically modified foods spark new calls for precautionary regulation (Wiener, 2004, 443. p.).

Also, in the 1980s the so-called space technology started to bloom, and in the 1990s technologies using virtual space started their march (see, for example: Klemens, 2010; to get more on AIs, Maloof, 2017).

In the 1990's the ownership and control of information generated by British science base has been transformed by a combination of regulatory changes designed to promote "the creation of wealth." The Regulation of Science and Technology (Studies in Regulation), edited by Helen Lawton-Smith, offers us a unique set of perspectives on a different regulatory mechanisms set out to achieve this. The contributors use and rely on a large amount of data and analysis to give a critique of political, economic, ethical, technological, and geographical issues connected to the allocation of resources to science and technology, the control and use of the information generated in the context, and the operation of regulatory agencies. 
As a matter of fact we also use telephones/cells, drones biometric systems, robots, AIs, too. Regulation is usually depicted as a single kind of rule or strategy. Jonathan B. Wiener states that "regulation is treated as if it comes in one type and has only one effect on technology, like an engine transmission that can shift into only forward or reverse. In reality, just as there are many different types of technologies (Wiener, J. B., 2004, 443. p. - see also: Bunch \& Hellemans, 2004; or McClellan \& Dorn, 2006), there are many different types of regulations. To name some, different regulatory apparatuses and mechanisms, such as technology requirements, performance standards/criteria, taxes, tradable allowances, and information disclosure, are assumed to have different effects on technological progress, and there might be other important consequences, concerning, for example property or privacy issues.

It is therefore clear that we need to break out of the narrow confines of risk assessment and develop an enlarged framework for thinking about and assessing technology in the context of public policy" (Chapman, 2007, 2. p.). Also, one may pose the question: Is the kind of regulatory tool important? Does it matter? Yes, it is. It does matter, indeed (Wiener, 1999). Technology requirements are supposed to embrace the intention to "force" industry to upgrade or to improve, and might foster the distribution of existing technology throughout the entire sector of industry. But then again, paradoxically, it also have an effect that may discourage or stagnate innovation of novel technologies by (over)specifying a particular technology and promising or guaranteeing no motivations or encouragements for further progresses (Breyer, 1982, 105. p.). Once requirements are authorised, the players of that certain sector have even fewer incentives to invent a better method. The reason is that the government is typically lags behind technology, as compared to industry, and because regulations almost always take years to spread and enforce, the "best technology" authorised by regulation may often be inferior to the best that industry could actually install. To put it simply with no intention to blame either the regulators or the industry/technology, industry and technology, and by implication innovation and invention, do not stop to wait for the cavalry of regulatory forces to arrive, though they do arrive with full forces, which is often not so well-thought of.

Although the recent developments of the issues above may be seen with a future prospective by Harry Armstrong and Jen Rae, they argue that "(...) regulation has struggled to be more future-facing, largely unequipped to cope with more fluid, fast moving technological development, preferring to let markets decide the direction of travel and intervening later as issues begin to surface. Anticipatory regulation helps reframe regulation as a supportive tool for the responsible development and use of new technologies and business models. New and existing 
methods are helping regulators do this in three important ways: Firstly, regulators/regulation can better support innovation as it emerges. Secondly, regulators/regulation can drive innovation directly. Lastly, regulators/regulation can respond faster or act pre-emptively to prevent public harm" (Armstrong \& Rae, 2017). Also, they state that "[a]s technologies create new products and services, and disrupt existing competitive advantage in the global market, creating a dynamic and flexible regulatory environment could secure the industries that will drive growth and create jobs" (Armstrong \& Rae, 2017). Although, some scholars may ask as well: Do novel "smart" technologies such as AI, robotics, smart drones and devices, social media, and automation threaten to disrupt the whole fabric of our society? (Though it seems futuristic, many movies and series have already attempted to answer some repercussion of the introduction of a novel technology, such as an AI. One of the best example is Humans, which is a science fiction tv series that premiered on Channel 4, and was written by the British team Sam Vincent and Jonathan Brackley, based on the Swedish science fiction drama Real Humans, the series focuses on the themes of artificial intelligence and robotics, concentrating on the socio-cultural, and psychological impact of the introduction/invention of anthropomorphic robots called "synths". It includes debates on the right and liability of high-tech AIs, and their legal status as well.) Or does technological innovation hold the potential to reform/transform our democracies, civic societies and legal/regulatory "attitude", creating ones that are more equal and liable or the opposite? Do we need to raise our voices or concerns or does the so-called regulation of technology happen, normatively or otherwise, smoothly? We appear to live an age of never-ending, multifaceted and disruptive technological innovation, one may ponder upon the ideas what, when, and how to structure regulatory interventions. Visibly, to answer these questions have become more and more challenging and for obvious reasons, demanding. Those who attempt to regulate often find themselves in a surrealistic and contradictory situation where they believe they are supposed to decide on either hasty action, for instance, regulations without crucial facts (As it will be shown later in my chapter on drone technology, in that case even the terminology blurred by the lack of consensus. As far as terminology is concerned, drones mainly refer to aerial vehicles, which can fly with no human operator or without any human assistance. However, for regulatory purposes, it should be admitted that many countries and international organizations have already accepted and formed wide-ranging definitions. In general aviation and spacerelated phraseology, a 'drone' usually related to any vehicle that can operate on multiple surfaces and/or in the air without the assistance of a human being on board to control it. Also, a small UAS 
manufacturer has to go through a 3-to-5year process to get hold of a type certificate, which allows the issuance of a standard airworthiness certificate, the small UAS would be technologically outdated and "old-fashioned" by the time it could complete the certification process. For more information, see: Notice of Proposed Rulemaking [NPRM]: DOTFAA, 2015, 9544, 9549.), or reserving to do nothing. Unsurprisingly, in such a case, caution tends to surpass risk. But, I assume, such caution purely functions as a kind of reinforcement of the status quo and it seems that it makes it harder for new technologies to enter the market in time. Though time after time some solution surfaces, one of the solutions might be offered by Mark Fenwick, Wulf A. Kaal and Erik P.M. Vermeulen. In their study, Regulation Tomorrow: What happens when technology is faster than law?, they suggest that law-making and regulatory design need to become more proactive, dynamic and responsive (Fenwick, Kaal \& Vermeulen, 2017). The reformation of the regulatory framework to address escalating and mounting regulatory concerns related to disruptive novel technologies has turned out to be a central issue in the world (See also: Scherer, 2016; or Zetzsche \& others, 2017) (Anne Chapman, for instance, decided to choose to examine the regulation of chemicals, to see why the regulatory system was so ill equipped to address the issues raised by endocrine disruption. She was concerned and felt that treating chemicals as isolated entities became the part of the problem, that was why her research turned out to be an investigation into how we think about and publicly assess technologies, taking synthetic chemicals as her prime example. See: Chapman, 2007).

Preparing a regulatory framework that is supposed to guarantee the safety of both the users and the public at the same time, while assisting the commercial use and consumers' pleasure and satisfaction of a novel technology does not seem to be an easy and stress-free task. Also, the question of how and what to regulate may bring up even more questions and concerns (Butenko \& Larouche, 2015, 52, 72. p.). Nowadays, it seems even more relevant, since innovation is more rapid (similarly to its development) and the global distribution of that technology is much faster, faster than ever before (See, for instance, McGrath, 2013. Or Brownsword \& Somsen, 2009). It is not difficult to imagine that such condition do not really support the burdensome work of regulators, thus it is often observed that regulators find it difficult to keep up with the rapid development of innovation/technology (See Marchant, Allenby \& Herkert (Eds.), 2011) ("Moore's Law notoriously states that the 'functional capacity of ICT products roughly doubles every 18 months', with the same dynamics manifesting in biotechnology, and namely in sequencing human genome. As a result, regulating innovation involves what is called a 'pacing problem' in the academic literature from the US, or the 'challenge of 
regulatory connection' or 'regulatory disconnection' in European-based scholarship." (Butenko \& Larouche, 2015); "The 'pacing problem' generally refers to the situation when technology develops faster than the corresponding regulation, the latter hopelessly falling behind. The metaphor of 'the hare and the turtle' is often brought up as a comparison. As summarized by Marchant and Wallach, 'at the rapid rate of change, emerging technologies leave behind traditional governmental regulatory models and approaches which are plodding along slower today than ever before'." (Butenko \& Larouche, 2015)) (Marchant \& Wallach, 2015).

The view and the justification of the necessity of risk assessment can be linked and supported by Rosario Girasa, who argues that Artificial intelligence (AI) is the state-of-the-art technological (r)evolution which keeps transforming the global economy and can be seen as a key part of the "Fourth Industrial Revolution.(Girasa, 2020, 70-80. p.)" Her book discusses the meaning, types, (sub)fields and applications of AI, as well as U.S. governmental policies and regulations, ethical and privacy issues, predominantly as they relate to and affect facial recognition programs and the Internet-of Things (IoT). There is a lengthy analysis of prejudice, and favourism, AI's effect on the recent and future job market, and how AI triggered fake news. The evident doom of the present regulatory systems/laws, concerning new technologies, is based on the fact that the progress of technology is obviously unstoppable, one may not find a single solution for such a complex and widely debated issue as the regulation of novel technologies without bumping into more and more and newer concerns related to privacy applying all meaning of it. But I need to emphasize the point that my doomsday attitude, regarding the regulation of novel tech, where a drone or an IA, for instance, is just a fine example besides mobile/cell phones or biometrics, I do not mean to argue that law makers are not up to their task, on the contrary. What I really endeavour to highlight is the fact that legal regulations and laws are destined to lag behind because of the inherent nature of the relationship between technology and law. Thus, I may opt for a revisionist (Through my chapters, I intend to use the expressions, such as revision, revisionist, and perfectionist, as my own coinage/tecnicus terminus as I have defined.) regulatory system instead of the existing perfectionist one. In order to avoid being misunderstood, I state that a revisionist method to deal with regulation of novel technologies may not attempt to construct flawless system of laws, since the liaison between law and technology can foreshadow a constant need for revision, as opposed to this, a perfectionist lawmaker feels the need and the urge to create a "perfect" laws and regulatory systems in order to assume to fulfil the traditional/classical ideology based on legal certainty and continuity. Obviously, 
my stand does not mean that we do not need legal certainty and continuity.

"Things do change. The only question is that since things are deteriorating so quickly, will society and man's habit change quickly enough?” - Isaac Asimov

\section{AI: dawn of the human factor - basics and definition(s)}

The first challenge one needs to face is the definition of AIs because even the terms "artificial intelligence" and "intelligent human behaviour" are not welldefined, however. Artificial intelligence designates the work processes of machines that would necessitate intelligence if performed by humans. The term "artificial intelligence" thus means "investigating intelligent problem-solving behaviour and creating intelligent computer systems" (See: Lackes, \& Siepermann, Künstliche Intelligenz) To go even deeper, we need to consider the fact that, at least, two kinds of artificial intelligence can be identified, the so-called weak artificial intelligence when the computer is simply an instrument for studying or probing cognitive processes, and the computer simulates intelligence. The other one is called strong or general artificial intelligence, when the processes in the computer are intellectual, self-learning processes. Computers can comprehend by means of the right software/programming and are able to optimise their own behaviour on the basis of their former behaviour and their experience (see, for exaple: Kerns, 2017). This comprises automatic networking with other machines, which leads to a dramatic scaling effect. It is also important to note that according to European commission "[a]rtificial intelligence (AI) refers to systems that display intelligent behaviour by analysing their environment and taking actions - with some degree of autonomy to achieve specific goals. (Communication from the Commission too the European Parliament...)" .Artificial intelligence and related technologies are altering, forming and reforming both the law and the legal profession. Particularly, technological progresses in fields ranging from machine learning to more cutting-edge robots, including sensors (with hyper sensitivity), virtual realities, algorithms, biometrics (See, for instance, a recent study on the subject: National Academies of Sciences, Engineering), drones, self-driving cars, and more sophisticated "human-like" robots are creating different/novel and formerly unimagined challenges for regulators (One of the best and up-to-date (though bulky) examples: a three-volume research conducted by the National Academies of Sciences, Engineering, and Medicine Hamilton \& others, 2020a; Hamilton \& others, 2020b; Hamilton \& others, 2020c).

Among many others, AI (some of the legal problems and concerns have already been brought up movie makers / writers. For example, A.I. Artificial Intelligence also known as A.I. ) is a 2001 American science fiction drama film directed by Steven Spielberg. The screenplay by 
Spielberg and screen story by Ian Watson were loosely based on the 1969 short story "Super toys Last All Summer Long" by Brian Aldiss. The movie also carries a hint of "The Adventures of Pinocchio, Le avventure di Pinocchio, is a novel for children by Italian author Carlo Collodi, written in Pescia, his work Can be seen as an early example of an AI. It is about the mischievous adventures of an animated marionette named Pinocchio and his father, a poor woodcarver named Geppetto. It was originally published in a serial form as La storia di un burattino in one of the earliest Italian weekly magazines for children, starting from 7 July 1881. All kinds of concerns and issues are brought up by the creators, including the rights of AIs, the regulation on their production, liability for "wrong-doing," privacy issues, and so on.

The European Association for Artificial Intelligence EurAI (formerly ECCAI) was established in July 1982 as a representative body for the European Artificial Intelligence community. Its aim is to promote the study, research and application of Artificial Intelligence in Europe. The next European Conference on AI (ECAI 2020) will take place in Santiago de Compostella. The conference was originally scheduled for June but due to the COVID19 situation it will take place at the end of August and the first week of September. The theme of the conference is "Paving the way towards HumanCentric AI" For more information, visit: https://www.eurai.org/), drones, bio- metric systems and their disruptive capabilities present a conspicuous example for the ability to pose a disruptive potential and regulatory challenges related to such disruption in the existing regulatory framework. AI seems an even more complicated issue because national and international law do not presently recognize $\mathrm{Al}$ as a subject of law, $\mathrm{Al}$ does not have legal personality and as such cannot be held personally liable for damages (Hresko Pearl, 2017). It must be admitted that AI might be able to do much good, including by making products and processes safer, it can raise concerns as well by doing harm. The harm may be both physical and immaterial. The might be as follows, safety and health of individuals, including loss of life, damage to property, intrusion of privacy, limitations to the right of freedom of expression, human dignity, or even discrimination, and can be in connection with a great variety of risks or/and threats (See the works by Isaac Asimov. He has already presented some major issues, concerning robots and AIs.). Evolving combinations of artificial intelligence, big data, and the applications have already been paid substantial attention concerning privacy/confidentiality and other ethical issues. Scholars feel the need to address comprehend these issues systematically and find mechanisms of addressing them that include stakeholders, civil society, to guarantee and safeguard that the benefit(s) of these novel technologies outweigh their disadvantages, or negative impacts. 
Information and communication technologies (ICTs) have long been documented and realized as having significant impacts on social, legal and economic arenas. As a consequence, they often seen as factors that cannot exist without regulatory supervision and, in addition, they call for ethical and social evaluation. Presently, one can observe two intertwining progresses that have the potential to add significantly and critically to the benefits of ICTs but that can also have undesirable effects on ethics and human rights. One of them is an accelerated rate of production and collection of big data, and the other one is novel ways of analysing and using this data. These two have been able to cloud other impacts, such as privacy concerns, not related to data protection. There are several ethical and human/personality rights issues/concerns, such as privacy, loss of employment, consent, identity, dual use, trust, power asymmetries, justice fairness, inequality, autonomy/agency discrimination, security, inclusion and so on (Stahl \& Wright, 2018). Artificial intelligence (AI) and big data analytics are the key technological drivers of what we call "smart information systems" (SIS). Examples of such intelligent sociotechnical systems abound - Google's search engine, Google Translate, Amazon's recommendation system, Amazon's Alexa home assistant, Facebook's likes, smartphones with GPS tracking, predictive policing systems, automated share dealing, healthcare and surgery robots, personal fitness applications, virtual and augmented reality, and many others, ranging from social network data analysis for advertising to traffic data prediction for energy conservation (Stahl \& Wright, 2018). When Stahl, Bernd Carsten Stahl and David Wright have coined the term SIS to point to a novel progress, the technologies elaborated on have a long history, as do some of the ethical questions they can be related to, such as privacy and data protection. A lot of the SIS use personal data, thus protecting such data is therefore an essential step to avoid growing concerns.

Many of the novel features of the European General Data Protection Regulation (GDPR) explicitly address the impact of SIS. Most of the new the novel features relevant to SIS are breach notifications, hefty financial penalties, data protection impact assessments(Privacy Impact Assessment), privacy by design (Privacy by Design Strong Privacy Protection...), and the so-called right to be forgotten (GDPR). Thus, a regulatory framework is supposed to focus on how to minimise the numerous risks of potential harm, particularly, the most noteworthy ones. The main risks associated with the usage of AI concern the application of rules/regulations intended to protect fundamental rights, including personal data and privacy protection and nondiscrimination), as well as safety and those concerns/issues related to and dealing with liability. Nowadays, the question of, 
what an AI is, is often asked by both experts and fans as well. Modern Information Technologies and the dawn of machines/mechanisms power-driven by artificial intelligence (AI) have already had a great influence on the world, including almost all walks of life in the $21 \mathrm{st}$ century (See, for instance, Anderson, Rainie \& Luchsinger, 2018). Workstations, computers, CPUs, algorithms and software make simpler everyday tasks, and it is difficult to envision how most of our life could be succeeded without them. Nevertheless, is it also unmanageable to imagine how most process steps or stages could be accomplished without the human factor? The famous name behind the idea of AI is John McCarthy (Lischka \& McCarthy, 25.10.2011), who began his ground-breaking research on this subject in 1955 and his assumption was that each and every aspect of learning and other domains of intelligence can be described so precisely and accurately that they can be computer-generated or simulated by a machine. Since 1948, McCarthy has been doing researching on artificial intelligence. The term, IA, was actually used by McCarthy in 1955 in a research application written with the legendary computer scientists Claude Shannon, Marvin Minsky and Nathaniel Rochester. The basic assumption of the scientists: "Every aspect of learning and other characteristics of intelligence can in principle be described so precisely that a machine can simulate it." From 1965 to 1980, McCarthy led the Artificial Intelligence Laboratory at
Stanford University. Three years later, in 1958, McCarthy developed the programming language Lisp, an acronym for List Processing, it refers to the structure of the source code of programs written in Lisp, which consists basically of lists. Joseph Weizenbaum programmed his legendary program Eliza in Lisp. Written questions are answered by the software, using natural language, which is considered to be a breakthrough or a revolutionary leap in computer-assisted language processing (Lischka \& McCarthy, 25.10.2011.) The regulation of artificial intelligence can be seen as the expansion of public sector policies and laws for stimulating and regulating artificial intelligence (AI); (Berryhill \& others, 2019)(Barfield, \& Pagallo, 2018) it is therefore related to the broader regulation of algorithms. The regulatory and policy landscape for AI is an emerging issue in jurisdictions globally, including in the European Union (Gesley \& others, 2019) (Report from the Commission to the European Parliament...). Regulation is considered necessary to both encourage $\mathrm{AI}$ and manage associated risks (Buiten, 2019) (Wirtz, Weyerer, \& Geyer, 2019). Regulation of AI through mechanisms such as review boards can also be seen as social means to approach the AI control problem (Sotala \& Yampolskiy, 2014). Some of the possible solutions can be find in an article, titled Solutions to address AI's anticipated negative impacts by Janna Anderson and Lee Rainie. They assume that, as a result of their canvassing offered 
solutions to the troublesome future produced by AI can be the following: first, improving collaboration across borders and stakeholder groups; second, developing policies to assure that development of AI will be directed at augmenting humans and the common good; and third, shifting the priorities of economic, political and education systems to empower individuals to stay ahead in 'the race with the robots' (Anderson \& Rainie, 2018).”

\section{Regulation of AI in the European} Union: Europe as a leader in trustworthy Artificial Intelligence

Europe has everything it needs to become a world leader in Artificial Intelligence (AI) systems that can be safely used and applied. It has outstanding research centres, secure digital systems and a strong position in robotics as well as competitive manufacturing and services sectors, covering almost all walks of life imaginable. The so-called White Paper presented today, presented by the Commission envisions a framework for reliable Artificial Intelligence, based on quality and trust. In partnership with the private and the public sector, the target is to mobilise resources and to create the proper and reasonable drives to accelerate deployment of AI, including by smaller and medium-sized enterprises. This European Union intends to work with its Member States and the research community, to promote, attract and keep talents. Since AI systems can be and are intricate and bear noteworthy risks in certain contexts, such as privacy issues and concerns. Thus, building trust is vital. Clear rules need to address high-risk AI systems without putting too much burden on less risky ones. As always, there are strict EU rules for consumer protection, to address unfair commercial practices and to protect personal data and privacy, are still to be applied. As for high-risk cases, such as in health, policing, privacy, or transport, AI systems are supposed to be transparent, traceable and guarantee human oversight/inaccuracy. As for lower risk AI applications, the Commission envisages a voluntary labelling scheme if they apply higher standards. All AI applications are welcome in the European market as long as they comply with EU rules (White Paper: On Artificial Intelligence...). AS customary in the EU, risk analyses must be done in advance in a company in order to protect employees when they work with robots. Furthermore, the so-called Machinery Directive sets a minimum standard/requirement that all machine products in Europe must meet. The Directive also provides for a manufacturer's risk assessment for any machine. The term machinery is defined as: an assembly, fitted with or intended to be fitted with a drive system other than directly applied human or animal effort, consisting of linked parts, at least one of which moves that are joined together for a specific application. Therefore robots are "machinery" for the purposes of the Directive. The machinery might not be 
operated till a safety briefing concerning the individual workplace of the employee working with the machinery has taken place. It is also suggested to regulate the use of the systems by establishing policies. If technical hitches with the system happen, these incongruities must also be included by the manufacturer of the machinery in its risk assessment. (Directive 2006/42/EC Of The European Parliament)

\section{The White Paper}

In 2017, the European Parliament issued a Resolution calling on the Commission to come up with innovative resolutions centred on civil law that could reply (effectively) to the prompt current development of robotics and AI. The Resolution, with an idea or intention of aiming for the preparation of new tort law concentrating on robots, proposes that a new definition of robot should be prepared. Responding to the Resolution, Paweł Księżak and Sylwia Wojtczak has prepared a study, which is made up of a legal-cognitive-linguistic analysis. It draws three conclusions: the first conclusion is that the definitional method is not the best approach to determining the scope of the regulation of robotics and $\mathrm{AI}$; the second one is that the Resolution is flawed by supposing that a new civil law solution should turn on differentiating between AI and robots and that robots should be treated as central in defining the scope of the regulation; and, lastly, that any new norms should be deep-seated in the concept of AI and not, as suggested and offered by the Resolution, in the concept of robot (Księżak, \& Wojtczak, 2020). According to the European Commission, and the rapid development and progress of Artificial Intelligence cannot be denied. It will have the potential to alter or even revolutionize our lives by improving healthcare, for instance, by making diagnosis more precise, allowing enhanced methods of prevention of illnesses, increasing the efficiency of production systems through predictive maintenance, or by improving the efficiency of other sectors, such as agriculture, environmental protection, or the security sector, and this list may go on.. Simultaneously, The EC argues that Artificial Intelligence (AI) involves numerous potential risks, such as opaque decision-making, gender-based and/or bias or other kinds of discrimination, intrusion in our private lives or, this novel technology can be used for criminal purposes as well. Since global competition has never been so competitive, a firm European approach is required, with bearing in mind the European strategy for AI presented in April 2018 (AI for Europe, COM/2018/237). A working definition can be, though it may be simple that AI can be defined as a collection of technologies that combine data, algorithms and computing power. Progresses in computing and the growing availability of data are therefore strategic drivers of the recent expansion of AI. Europe has the potential to combine its technological and industrial 
assets with a high-grade digital infrastructure and a regulatory framework constructed on its fundamental values and principles to turn into a global leader in innovation in the data economy and its applications as set forth in the European data strategy (Communication from the Commission to the European Parliament...). The White Paper, presented by European Commission in 19 . February, 2020, offers policy alternatives in order to facilitate a dependable and safe improvement of AI in Europe, with respect to the (core) values and rights of EU citizens.

The main building blocks of this White Paper are: "The policy framework setting out measures to align efforts at European, national and regional level. In partnership between the private and the public sector, the aim of the framework is to mobilize resources to achieve an ecosystem of excellence along the entire value chain, starting in research and innovation, and to create the right incentives to accelerate the adoption of solutions based on AI, including by small and medium-sized enterprises (SMEs). The key elements of a future regulatory framework for AI in Europe that will create a unique ecosystem of trust. To do so, it must ensure compliance with EU rules, including the rules protecting fundamental rights and consumers' rights, in particular for AI systems operated in the EU that pose a high risk. Building an ecosystem of trust is a policy objective in itself, and should give citizens the confidence to take up AI applications and give companies and public organisations the legal certainty to innovate using AI.

The Commission strongly supports a human-centric approach based on the Communication on Building Trust in Human-Centric AI8 and will also take into account the input obtained during the piloting phase of the Ethics Guidelines prepared by the High-Level Expert Group on AI" (White Paper: On Artificial Intelligence...). Representing the European Commission President Ursula von der Leyen announced the plan (Shaping Europe's digital future...) at a press conference with the goal is to promote "trust, not fear." The plan also includes measures to update the European Union's 2018 AI strategy (Rabesandratana, 2018) and pump billions into Research and Development over the next decade (Shaping Europe's digital future...).

It can be seen that the EU attempts to come up with a solid and all-inclusive regulatory framework, with no doubts on the probabilities of threats and risks as well. Thus, it not a surprise that The commission requests binding rules for "high-risk" (The EU sticks to its risk-based solutin here as well as in the case of drones.) uses of AI in sectors like health care, transport, or criminal justice. Accordingly, the criteria to determine/define risk may include considerations such as whether it could be harmful to someone, by an AI driven car or a medical device/tool, for instance, or whether a person has little say in whether 
they're affected by an AI's decision, such as when it is used in job recruitment or policing. For high-risk scenarios, the commission intends to put a stop to indecipherable "black box" AIs by demanding human oversight. The rules needs to govern the large data sets used in training AI systems, safeguarding and guaranteeing that they are legally acquired, traceable to their source, and sufficiently broad to train the system. The liability for an AI system's actions is supposed to be dealt with by the law, from both the users' sides and the manufacturers' or designers' sides as well.

As for the high-risk applications have to be presented to be compliant with the rules/regulations before being installed in the European Union. The commission also proposes to offer a "trustworthy AI" certification, to inspire voluntary compliance in low-risk uses. Although EU countries such as Germany have announced plans to install these systems, officials say they often violate EU privacy laws, including special rules for police work (Grüll, 2020). I argue that the new AI strategy is not merely about regulation. The commission may be able to produce an "action plan" for incorporating AI into public services such as public transport and health care, and even more.

The commission is calling for more R\&D, including AI “excellence and testing centres" and a new industrial partnership for AI that could invest billions. Alongside its AI plan, the commission also drawn a separate strategy to encourage data sharing, in part to backing up the development of AI.

\section{Report No. A9-0186/2020 presented by the European Parliament}

The Report observes the necessity of the mutual goal of European Union for a regulatory framework for the progress and expansion, distribution and use of artificial intelligence, robotics and associated/interrelated technologies ('regulatory framework for AI') should allow citizens to share the benefits drawn from their potential, while protecting citizens from the potential risks of such technologies and upholding and supporting the reliability of such technologies in the European Union and elsewhere; that framework should be built on Union law and values and guided by the principles of transparency, fairness, accountability and responsibility, understanding and in accordance with the core values of the European Union.

This regulatory framework is of vital importance in order to avoid the disintegration of the Internal Market, which may result from conflicting and different national legislation. The common regulatory framework can help nurture much needed investment, improve data infrastructure and support research.

Also it should consist of common legal obligations and ethical principles as set out in the proposal for a Regulation. Still, it should be established and be consistent with the improved regulation guidelines. The Union has a strict legal framework in place to guarantee and to safeguard, inter 
alia, the protection of personal data and privacy and non-discrimination, to support and encourage gender equality, environmental protection and consumers' rights; whereas such a legal framework consisting of an extensive body of horizontal and sectoral legislation, as well as the existing rules on product safety and liability, will continue to apply concerning artificial intelligence, robotics and related technologies, though certain adjustments of specific legal instruments may be necessary to reflect the digital transformation and address new challenges posed by the use of artificial intelligence. The report also states that there are (major) concerns that the recent European Union legal framework, including the consumer law and employment and social acquis, data protection legislation, product safety and market surveillance legislation, as well as antidiscrimination legislation may no longer be suitable for purpose to effectively challenge and confront the risks created by artificial intelligence, robotics and related technologies. And, in addition to amendments to current legislation, legal and ethical inquiries with regard to AI technologies ought to be addressed through an effective, comprehensive and future-proof regulatory framework of European Union law reflecting the Union's principles and values as preserved and protected in the Treaties and the Charter of Fundamental Rights that ought to avoid over-regulation, by only closing existing legal gaps, and increase legal certainty/decrease legal uncertainty for businesses and citizens alike, namely by including mandatory measures to prevent practices that would undoubtedly undermine fundamental rights (del Blanco, 8.10.2020). As it is suggested by and can be drawn from this report as well, the existing EU regulatory framework for AI seems to struggle with not having the nature of being "common" (for the purpose of EU harmonization processes) and with being unfit to face the challenges presented by AI.

Needless to say, I assume that can be applied to any novel technologies by implication. AI is set to transform all walks of life, there may not be any segments of society remaining untouched or undisturbed. As a general-purpose technology, its constant development and application will speed up innovation across all dimensions of human enterprise. These changes can both offer remarkable progresses to public welfare and we must not forget that they can create unparalleled public risk as well. Thus, it has been and will be crucial to attempt to minimize that risk, plus, it is vital to comprehend how the progress and application of AI is presently being ruled and overseen. Remodelling or (re)forming the regulatory framework to address accumulating and growing regulatory issues/concerns related to (disruptive or/novel) technologies comes to be more and more essential. Planning or developing a regulatory framework that guarantees the protection of users and the public, while aiding the commercial use and consumer enjoyment of disruptive 
innovation seems even more complex and complicate(Butenko \& Larouche, 2015). This appears "factual" in contemporary settings, where innovation is faster and the global distribution of that technology is much faster (McGrath, 2013; Desilver, 2014).

\section{AI regulation US (Guidance for} Regulation of Artificial Intelligence Applications)

The government of the United States has already taken numerous initiatives to address the growing concern of AI's relationship to national security and its regulation. Among them is the creation of the Defense Innovation Board launched in 2016 with a renewable 2-year mandate whose mission, in part, is to give the Secretary of Defense and other related government officials with advice and recommendations to address future challenges in technology and capabilities (Pellerin, 2016; Ten Commandments of Software...). On February 11, 2019, President Trump signed Executive Order 13859 announcing the American AI Initiative - the United States' national strategy on artificial intelligence. This strategy is a concentrated effort to encourage and protect national AI technology and innovation. The Initiative implements a whole-of-government strategy in collaboration and engagement with the private sector, academia, and the public, and like-minded international partners in agreement with it. It guides the Federal government to follow five pillars for progressing AI: first, invest in AI research and development $(\mathrm{R} \& \mathrm{D})$, the next is to unleash AI resources, third is to eliminate barriers to AI innovation, the penultimate is to educate/train an AIready workforce, and the last is to support an international environment that is supportive of American AI innovation and its responsible use. The U.S. is also supportive to AI tech in order to aid the Federal government work more effectively in its own services and missions in dependable ways.

In February 2020, the White House released the American Artificial Intelligence Initiative: Year One Annual Report. In the year since the AI Executive Order was signed, the Administration called for record amounts of AI R\&D investment, led the development of the first international statement on AI Principles, issued the first-ever strategy for engagement in AI technical standards, published the first-ever reporting of government-wide non-defense AI R\&D spending, and released the first-ever AI regulatory document for the trustworthy development, testing, deployment, and adoption of AI technologies (Maintaining American Leadership...).

Regulation is commonly defined as "the sustained and focused attempt to alter the behaviour of others according to standards or goals, with the intention of producing a broadly identified outcome" (One of the latest views on the subject presented in the form of a case study by Leenders, 2019) (Brownsword, 2017; Brownsword \& 
Somsen, 2009; Moses, 2013). For a regulatory regime to be effective, it needs to have a clear (working) definition of what it regulates. Regrettably, there are numerous different definitions of AI circulating among experts in the field.(Scherer, 2016 for more information on $\mathrm{AI}$ and updates, consult, for example, this website: The Regulation of Artificial Intelligence -A Case Study of the Partnership on AI).

The non-technical definition that is predominant and widespread in the literature on AI policy is that an AI is any digital tool or system that is capable of performing tasks that, if performed by a human, would be said to require intelligence (Brundage \& others, 2018; Scherer, 2016). A vital implication of this definition is that AI is a technology assuming general purpose, the combination of intelligence with computing properties has the possibility to increase productivity across all industries by speeding up invention/innovation (Brundage \& Bryson, 2016)- The repeated importance of AI is powered by the progress of a (wide) range of machine learning (ML) techniques. These techniques are used to create digital systems that can "improve their performance on a given task over time through experience" (Brundage \& others, 2018). A combination of cheaper and enhanced and upgraded computer processing power, access to enormous and organised training datasets, and algorithmic innovation has enabled machine learning academics and professionals to make important innovations in a great variety of domains generally assumed to be key elements of AI (Brundage \& Bryson, 2016; Calo, 2017)-

The risk to public welfare springs from two different forms of AI. The AI literature categorises existing and up-todate ML techniques as "narrow AI", consisting of greatly specialized statistical models that have been trained to match or surpass performance at a human level at a specific task, in a specifically and precisely well-defined environment (Campolo \& Others, 2017). The progress and use of narrow AI is connected with substantial risks concerning personal privacy, bias, inequality and prompt computerisation/ robotics (Brundage \& others, 2018 - to get to know more on limiting technology: Mulligan, 2008). One of the major concerns is definitely connected to the above mentioned personal privacy, which can be said to be greatly linked to (novel) technology as well. However, the mediagenerated doubts/issues/concerns and (great) expectations of AI commonly concern Artificial General Intelligence (AGI). By definition, AGI refers to a system that equals or surpasses human level performance at any task across multiple domains, independent of its training milieu.

Though there is presently no clear progress "line" toward AGI, a survey of AI experts gives a $10 \%$ chance of such AI being developed by 2024, and a 50\% chance of it being developed by 2050 (Grace \& others, 2017; Bostrom, Dafoe \& 
Flynn, 2017). AGI presents public welfare risks on a different order of magnitude, including geopolitical security concerns, labour market dislocations and extreme economic inequality.

Some researchers even identify an existential risk to the survival of our species, if we fail to control or align an AGI with our values (Bostrom, Dafoe \& Flynn, 2017). Other researchers, for example, Katja Grace, John Salvatier, Allan Dafoe, Baobao Zhang and Owain Evans, while analysing the possible impacts and progresses in artificial intelligence (AI), they predict that AI will transform modern life by remodelling transportation, health, science, finance, and the military, and we may add regulation (see: Calo, 2015, 513. p.) and privacy as well. In order to adapt public policy/regulation, it seems essential for us to better anticipate these progresses. They report their findings from a large survey of machine learning researchers on their beliefs about progress in AI. These researchers predict that "AI will outperform humans in many activities in the next ten years, such as translating languages (by 2024), writing high-school essays (by 2026), driving a truck (by 2027), working in retail (by 2031), writing a bestselling book (by 2049), and working as a surgeon (by 2053). Researchers believe there is a $50 \%$ chance of AI outperforming humans in all tasks in 45 years and of automating all human jobs in 120 years, with Asian respondents expecting these dates much sooner than North Americans.
These results will inform discussion amongst researchers and policymakers about anticipating and managing trends in AI" (Grace \& others, 2018).

\section{Conclusion}

This study has only attempted to offer some preliminary observation related to the discussion on the development and application of AI that seem to present unique regulatory challenges. In addition, it looks that the prospect of AGI can create a competitive dynamic that prioritizes the fast development of AI over the safe development of AI.

The dynamic affects the corporations developing AI technology, and the countries tasked with regulating them. Traditional regulatory solutions seem illsuited to the task of minimizing public risk while sustaining innovation. Self-regulation can be identified as an alternative form of governance where an industry designs/creates and puts in force new rules, standards and ethics for themselves, often in "areas where government rules are lacking" (Haufler, 2001, 8-10. p.). I posit that a self-regulatory system has the possibility to be an effective and practical solution to the unique regulatory challenges of AI, and could assist and allow the AI industry to overcome the competitive dynamic that incentivises AI progress/growth haste over safety.

\section{References}

AI for Europe, COM/2018/237 final

Available: 
https:/ /ec.europa.eu/transparency/re gdoc/rep/1/2018/EN/COM-2018237-F1-EN-MAIN-PART-1.PDF [accessed 2 Sep 2020]

Anderson, J. \& Rainie, L. (2018). 2. Solutions to address AI's anticipated negative impacts. Pew Research Center. Available:

https://www.pewresearch.org/interne t/2018/12/10/solutions-to-addressais-anticipated-negative-impacts / [accessed 19 Dec 2020]

Anderson, J., Rainie, L. \& Luchsinger, A. (2018). Artificial Intelligence and the Future of Humans. Pew Research Center.

Available:

https://www.pewresearch.org/interne t/2018/12/10/artificial-intelligenceand-the-future-of-humans / [accessed 19 Dec 2020]

Armstrong, H.\& Rae, J. (2017). A working model for anticipatory regulation. A working paper. Available: https://www.nesta.org.uk/report/aworking-model-for-anticipatoryregulation-a-working-paper/ [accessed 27 Aug 2020]

Barfield, W. \& Pagallo, U. (2018). Research bandbook on the law of artificial intelligence.

Edward Elgar Publishing, Cheltenham.

Berryhill, J. \& others (2019). Hello, World: Artificial Intelligence and its Use in the Public Sector. OECD Working Papers on Public Governance, No. 36,. Available: https://oecdopsi.org/wpcontent/uploads/2019/11/AI-
Report-Online.pdf [accessed $19 \mathrm{Dec}$ 2020]

del Blanco, I. G. (8.10.2020). Report with recommendations to the Commission on a framework of ethical aspects of artificial intelligence, robotics and related technologies (2020/2012(INL)). Committee on Legal Affairs. Available: https://www.europarl.europa.eu/doce o/document/A-9-2020-0186_EN.pdf [accessed 29 Dec 2020]

Bostrom, N., Dafoe, A. \& Flynn, C. (2017). Policy Desiderata in the Development of Superintelligent AI. Future of Humanity Institute. Available: http://governance40.com/wpcontent/uploads/2018/12/aipolicy.pd f [accessed 5 Dec 2020]

Breyer, S. (1982). Regulation and its reform. Harvard University Press, Cambridge, MA. Available: https://www.scienzegiuridiche.unirom a1.it/sites/default/files/docenti/dalbe rti/breyer-regulation-and-itsreform.pdf [accessed 27 Aug 2020]

Brownsword, R. (2008). Rights, Regulation and the Technological Revolution. Oxford University Press, Oxford. DOI 10.1093/acprof:oso/9780199276806.0 01.0001

Brownsword, R. (2017). From Erewhon to AlphaGo: For the sake of human dignity, should we destroy the machines? Law, Innovation and Technology, 9/1, 117-153. DOI 10.1080/17579961.2017.1303927 
Brownsword, R \& Somsen, H. (2009)

Law, Innovation and Technology:

Before We Fast Forward - A Forum

for Debate. Law, Innovation and

Technology, 1/1, 1-73, DOI

10.1080/17579961.2009.11428364 To

link to this article:

https:/ / doi.org/10.1080/17579961.20

09.11428364

Brundage, M. \& Bryson, J. (2016). Smart

Policies for Artificial Intelligence.

ArXiv,

Available: https://arxiv.org/pdf/1608. 08196.pdf [accessed 4 Dec 2020]

Brundage, M. \& others (2018). The

Malicious Use of Artificial Intelligence:

Forecasting, Prevention, and Mitigation.

Future of Humanity Institute,

University of Oxford, Centre for the

Study of Existential Risk, University of

Cambridge, Center for a New

American Security, Electronic Frontier

Foundation. DOI

10.17863/CAM.22520 Available:

https:/ /www.repository.cam.ac.uk/bit stream/handle/1810/275332/1802.07 228.pdf? sequence $=1$ \&is Allowed $=\mathrm{y}$ [accessed 4 Dec 2020]

Buiten, M. C. (2019). Towards Intelligent

Regulation of Artificial Intelligence.

European Journal of Risk

Regulation, 10/1, 41-59. DOI

10.1017/err.2019.8 Available:

https://www.cambridge.org/core/ser vices/aop-cambridge-

core/content/view/AF1AD1940B70

DB88D2B24202EE933F1B/S186729

9X19000084a.pdf/towards_intelligent _regulation_of_artificial_intelligence.p

df [accessed 19 Dec 2020]

Bunch, B. \& Hellemans, A. (2004). The

History of Science and Technology: A

Browser's Guide to the Great Discoveries,

Inventions, and the People Who Made Them

from the Dawn of Time to Today. Mifflin

Company, Houghton. Or McClellan, J.

E. \& Dorn, H. (2006). Science and

Technology in World History. The Johns

Hopkins University Press.

Butenko, A. \& Larouche, P. (2015).

Regulation for Innovativeness or

Regulation of Innovation? Law,

Innovation and Technology, 7/1, 52-82.

DOI 10.1080/17579961.2015.1052643

Calo, R. (2015). Robotics and the lessons of cyberlaw. California Law Review, 103/3, 513-563. DOI

10.2139/ssrn.2402972 Available:

https://29qish1lqx5q2k5d7b491joo-

wpengine.netdna-ssl.com/wp-

content/uploads/2015/07/Calo_Rob

ots-Cyberlaw.pdf [accessed 5 Dec

2020]

Calo, R. (2017). Artificial Intelligence

Policy: A Primer and Roadmap. UC

Davis Law Review, 51/2, 339-435. DOI

10.2139/ssrn.3015350 Available

at: https://lawreview.law.ucdavis.edu/

issues/51/2/Symposium/51-

2_Calo.pdf [accessed 4 Dec 2020]

Campolo, A. \& Others (2017). AI Now

2017 Report. AI Now Institute, New

York. Available:

https://ainowinstitute.org/AI_Now_

2017_Report.pdf [accessed 5 Dec

2020] 
Chapman, A. (2007). Democratizing Technology: Risk, Responsibility and the Regulation of Chemicals, Earthscan Publications, London.

Communication from the Commission too the European Parliament, The European Council, the Council, The European Economic and Social Committee and the Committee of the Regions: Artificial Intelligence for Europe Brussels, 25.4.2018 $\operatorname{COM}(2018) 237$ final Available: https:/ / eur-lex.europa.eu/legalcontent/EN/TXT/PDF/?uri=CELE $\mathrm{X}: 52018 \mathrm{DC} 0237 \&$ from $=\mathrm{EN}$ [accessed 19 Dec 2020]

Communication from the Commission to the European Parliament, the Council, the European Economic and Social Committee and the Committee of the Regions. $\operatorname{COM}(2020) 66$ final Available: https:/ / ec.europa.eu/info/sites/info/ files/communication-europeanstrategy-data-19feb2020_en.pdf [accessed 2 Sep 2020]

Department of Transportation, Federal Aviation Administration [DOT-FAA] (2015). Operation and Certification of Small Unmanned Aircraft System, Federal Register, 80/35. Available: https://www.govinfo.gov/content/pk g/FR-2019-02-13/pdf/201900758.pdf [accessed 25 Mar 2019]

Desilver, D. (2014). Chart of the Week: The Ever-Accelerating Rate of Technology Adoption. Pew Research Center report. available: https:/ /www.pewresearch.org/fact- $\operatorname{tank} / 2014 / 03 / 14 /$ chart-of-the-weekthe-ever-accelerating-rate-oftechnology-adoption/ [accessed 3 Sep 2020]

DIRECTIVE 2006/42/EC OF THE EUROPE AN PARLIAMENT AND OF THE COUNCIL of 17 May 2006 on machinery, and amending Directive 95/16/EC (recast) Available: https://eur-lex.europa.eu/legalcontent/EN/TXT/PDF/?uri=CELE $\mathrm{X}: 32006 \mathrm{~L} 0042 \&$ from $=H U$ [accessed 2 Sep 2020]

A European approach to Artificial intelligence.

Shaping Europe's digital future:

Commission presents strategies for data and Artificial Intelligence: https://digitalstrategy.ec.europa.eu/en/node/159/p rintable/pdf [accessed 19 Dec 2020]

Fenwick, M., Kaal, W. A. \& Vermeulen, E. P. M. (2017). Regulation Tomorrow: What Happens When Technology Is Faster than the Law. American University Business Law Review, 6/3., 561-594.

General Data Protection Regulation. Available: https://gdpr-info.eu/ [accessed 19 Dec 2020]

Gesley, J. \& others (2019). Global Legal

Research Directorate, issuing body. Regulation of Artificial Intelligence in Selected Jurisdictions. Law Library, Library of Congress. LCCN 2019668143 Available: https://www.loc.gov/law/help/artific ial-intelligence/regulation-artificial- 
intelligence.pdf [accessed 19 Dec 2020]

Girasa, R. (2020). Artificial Intelligence as a Disruptive Technology - Economic Transformation and Government Regulation. Palgrave Macmillan. DOI 10.1007/978-3-030-35975-1

Grace, K. \& others (2017). When Will AI Exceed Human Performance? Evidence from AI Experts. Future of Humanity Institute, UK and AI Impacts, Berkeley, USA. Available: https:/ / arxiv.org/abs/1705.08807 [accessed 4 Dec 2020]

Grace, K. \& others (2018). Viewpoint: When Will AI Exceed Human Performance? Evidence from AI Experts. Journal of Artificial Intelligence Research, Vol 62, 729-754. DOI 10.1613/jair.1.11222 Available: https:/ /jair.org/index.php/jair/article /view/11222/26431 [accessed 5 Dec 2020]

Grüll, P. (2020). Germany's plans for automatic facial recognition meet fierce criticism. Euractiv.de. Available: https://www.euractiv.com/section/da ta-protection/news/german-ministersplan-to-expand-automatic-facialrecognition-meets-fierce-criticism/ [accessed 2 Sep 2020]

Guidance for Regulation of Artificial Intelligence Applications https:/ /www.whitehouse.gov/wpcontent/uploads/2020/01/DraftOMB-Memo-on-Regulation-of-AI-17-19.pdf?utm_source=morning_brew [accessed 2 Sep 2020]
Hamilton, B. A. \& others (2020a). Airports and Unmanned Aircraft Systems, Volume 1: Managing and Engaging Stakeholders on AS in the Vicinity of Airports. In National Academies of Sciences, Engineering, and Medicine, The National Academies Press, Washington, DC. DOI 10.17226/25599

Hamilton, B. A. \& others (2020b). Airports and Unmanned Aircraft Systems, Volume 2: Incorporating UAS into Airport Infrastructure Planning Guidebook. In National Academies of Sciences, Engineering, and Medicine, The National Academies Press, Washington, DC. DOI 10.17226/25606

Hamilton, B. A. \& others (2020c). Airports and Unmanned Aircraft Systems, Volume 3: Potential Use of UAS by Airport Operators. In National Academies of Sciences, Engineering, and Medicine, The National Academies Press, Washington, DC. DOI 10.17226/25607

Haufler, V. (2001). A Public Role for the Private Sector: Industry Self-Regulation in a Global Economy. Carnegie Endowment for International Peace, Washington, D.C.Hresko Pearl, T. (2017). Fast \& Furious: The Misregulation of Driverless Cars. New York University Annual Survey of American Law, 73/1, 19-72. Available: https://ttuir.tdl.org/bitstream/handle/2346/734 20/Fast $\% 20 \% 26 \% 20$ Furious $\% 2073 \%$ 20NYU\%20Ann $\% 20$ Sur $\% 20$ Am $\% 20$ 
L\%2019.pdf?sequence $=1$ \&isAllowed $=$ y [accessed 21 Dec 2020]

Kerns, J. (2017). What's the Difference

Between Weak and Strong AI?

machinedesign.com.

https:/ /www.machinedesign.com/mar kets/robotics/article/21835139/whats -the-difference-between-weak-and-

strong-ai or

https://www.internetsociety.org/reso urces/doc/2017/artificial-intelligenceand-machine-learning-policy-

paper/?gclid $=\mathrm{Cj} 0 \mathrm{KCQiA} 5 \mathrm{vb}$

[accessed 19 Dec 2020]

Klemens, G. (2010). The Cell phone: The

History and Technology of the Gadget That

Changed the World. McFarland and

Company, London.

Księżak, P. \& Wojtczak, S. (2020). AI

versus robot: in search of a domain

for the new European civil law. Law,

Innovation and Technology, 12/2, 297-317.

DOI 10.1080/17579961.2020.1815404

Lackes, R. \& Siepermann, M. Künstliche

Intelligenz (KI). In Gabler

Wirtschaftlexikon

http://wirtschaftslexikon.gabler.de/Ar

chiv/74650/kuenstliche-intelligenz-ki-

v12.html [accessed19 Dec 2020]

Leenders, G. (2019). The Regulation of

Artificial Intelligence - A Case Study of

the Partnership on AI, Becoming

Human.https://becominghuman.ai/th

e-regulation-of-artificial-intelligence-a-

case-study-of-the-partnership-on-ai-

c1c22526c19f [accessed 4 Dec 2020]

Leenes, R. (2019). Regulating New

Technologies in Times of Change. In
Reins, L. (Ed.) Regulating New

Technologies in Uncertain Times. Springer,

The Hague. DOI 10.1007/978-94-

6265-279-8_1

Leenes, R. \& others. (2017). Regulatory

challenges of robotics: some guidelines

for addressing legal and ethical issues.

Law, Innovation and Technology, 9/1, 1-

44. DOI

10.1080/17579961.2017.1304921

Available:

https://research.tilburguniversity.edu/ files/23365230/Regulatory_challenges _of_robotics_some_guidelines_for_ad dressing_legal_and_ethical_issues.pdf [accessed 26 Aug 2020]

Lischka, K. \& McCarthy, J. (25.10.2011)

Der Vater der Rechner-Cloud ist tot.

Spiegel Online. Available:

www.spiegel.de/netzwelt/web/john-

mccarthy-der-vater-der-rechner-cloudist-tot-a-793795.html [accessed 14 Dec 2020]

Maintaining American Leadership in Artificial Intelligence. (2019). / Presidential

Documents / Federal Register, 4/31, 3967-3972

https://www.govinfo.gov/content/pk

g/FR-2019-02-14/pdf/2019-

02544.pdf [accessed 2 Sep 2020]

Maloof, M. (2017). Artificial Intelligence: An

Introduction. Georgetown University,

Washington DC. Available:

http:// people.cs.georgetown.edu/ m

aloof/cosc270.f17/cosc270-intro-

handout.pdf [accessed 27 Aug 2020]

Marchant, G. E. \& WALLACH, W.

(2015) Coordinating Technology 
Governance. Issues in Science and

Technology 31/4. Available:

https:/ / issues.org/coordinating-

technology-governance/ [accessed 11

Nov 2020]

Marchant, G. E., Allenby, B. R. \&

Herkert, J. R. (Eds.) (2011). The

Growing Gap Between Emerging

Technologies and Legal-Ethical Oversight:

the Pacing Problem 3. Springer, New

York. DOI 10.1007/978-94-007-1356-

7

McGrath, R. (2013). The Pace of

Technology Adoption is Speeding Up.

Harvard Business Review, Nov. 25.

Available:

https://hbr.org/2013/11/the-pace-

of-technology-adoption-is-speeding-

up [accessed 4 Nov 2018]

Moses, L. B. (2013). How to Think about

Law, Regulation and Technology:

Problems with 'Technology' as a

Regulatory Target. Law, Innovation and

Technology, 5/1, 1-20. DOI

10.5235/17579961.5.1.1 [accessed 4

Dec 2020]

Mulligan, C. M. (2008). Perfect

Enforcement of Law: When to Limit

and When to Use Technology.

Richmond Journal of Law and Technology,

14/4, 1-49. Available:

https://scholarship.richmond.edu/cgi

/viewcontent.cgi?article $=1295 \&$ conte

$\mathrm{xt}=$ jolt [accessed 4 Dec 2020]

National Academies of Sciences,

Engineering, and Medicine. Life-Cycle

Decisions for Biomedical Data: The

Challenge of Forecasting Costs.
Washington, DC: The National

Academies Press. (2020) DOI:

$10.17226 / 25639$.

Pellerin, C. (2016). Defense Innovation Board

Makes Interim Recommendations,

Department Of Defense News, Oct.

5.

https://dod.defense.gov/News/Articl e/Article/965196/defense-innovationboard-makes-

interimrecommendations/ [accessed 2

Sep 2020]

Privacy Impact Assessment (PIA) Good

Practice. CNIL, 2015. Available:

https://www.cnil.fr/sites/default/files

/typo/document/CNIL-PIA-1-

Methodology.pdf [accessed 19 Dec

2020]

Privacy by Design Strong Privacy Protection-

Now, and Well into the Future; A Report

on the State of PbD to the 33rd

International Conference of Data

Protection and Privacy

Commissioners. Information

Commissioner's Office,2008.

Available: https://www.ipc.on.ca/wpcontent/uploads/Resources/PbDRep

ort.pdf [accessed 21 Dec 2020]

Rabesandratana, T. (2018). With $€ 1.5$

billion for artificial intelligence research,

Europe pins hopes on ethics. Science, Apr

25,

https://www.sciencemag.org/news/2

018/04/15-billion-artificial-

intelligence-research-europe-pins-

hopes-ethics [accessed 2 Sep 2020]

The Regulation of Artificial

Intelligence-A Case Study of the 
Partnership on AI

https:/ / nikolanews.ndnsocial.com.hk/

the-regulation-of-artificial-

intelligence $\% \mathrm{E} 2 \% 80 \% 8 \mathrm{~A}$ -

$\% \mathrm{E} 2 \% 80 \% 8 \mathrm{Aa}$-case-study-of-the-

partnership-on-ai/ [accessed 4 Dec 2020]

Report from the Commission to the European

Parliament, the Council and the European

Economic and Social Committee: Report on

the safety and liability implications of

Artificial Intelligence, the Internet of Things

and robotics. European Commission,

Directorate-General for Justice,

Brussels, 2020. Available: https://eur-

lex.europa.eu/legal-

content/EN/TXT/PDF/?uri=CELE

$\mathrm{X}: 52020 \mathrm{DC} 0064 \&$ from $=$ en [accessed

19 Dec 2020

Scherer, M. U. (2016). Regulating

Artificial Intelligence Systems: Risks,

Challenges, Competencies, and

Strategies. Harvard Journal of Law and

Technology 29/2, 353-400. Available:

http://jolt.law.harvard.edu/articles/p

df/v29/29HarvJLTech353.pdf

[accessed 4 Dec 2020]

Shaping Europe's digital future: Commission

presents strategies for data and Artificial

Intelligence.

https:/ /ec.europa.eu/commission/pre

sscorner/detail/en/ip_20_273

[accessed 2 Sep 2020]

Sotala, K. \& Yampolskiy, R. V.

(2014). Responses to catastrophic AGI risk: a survey. Physica Scripta, 90/1.

DOI 10.1088/0031-

8949/90/1/018001 Available: https://iopscience.iop.org/article/10. 1088/0031-8949/90/1/018001/pdf [accessed 19 Dec 2020]

Stahl, B. C. \& Wright, D. (2018). Ethics and Privacy in AI and Big Data: Implementing Responsible Research and Innovation. IEEE Security and Privacy, 16/3, 26-33. DOI 10.1109/MSP.2018.2701164 Available: https://ieeexplore.ieee.org/document /8395078 [accessed 21 Dec 2020]

Ten Commandments of Software: Working

Document, Defense Innovation Board (April 20, 2018), https://media.defense.gov/2018/Apr /22/2001906836/-1/-

1/0/DEFENSEINNOVATIONBO ARD_TEN_COMMANDMENTS_O F_SOFTWARE_2018.04.20.PDF [accessed 2 Sep 2020]

White Paper: On Artificial Intelligence - A European approach to excellence and trust.

For more information, visit: https://ec.europa.eu/info/sites/info/ files/commission-white-paperartificial-intelligence-feb2020_en.pdf [accessed 2 Sep 2020]

Wiener, J. B. (1999). Global environmental regulation: instrument choice in legal context. The Yale Law Journal, 108/4, 677800. DOI $10.2307 / 797394$

Wiener, J. B. (2004). The regulation of technology, and the technology of regulation. In Technology in Society, 26/2, 483-500. Available: https://scholarship.law.duke.edu/facu lty_scholarship/1163/ [accessed 27 Aug 2020] 
Wirtz, B. W., Weyerer, J. C. \& Geyer, C. (2019). Artificial Intelligence and the Public Sector-Applications and Challenges. International Journal of Public Administration, 42/7, 596-615. DOI 10.1080/01900692.2018.1498103

Available:

https://www.tandfonline.com/doi/ab s/10.1080/01900692.2018.1498103

[accessed 19 Dec 2020]

Zetzsche, D. A. \& Others. (2017).

Regulating a Revolution: From

Regulatory Sandboxes to Smart

Regulation. Fordham Journal of Corporate and Financial Law 23/1, 31-104. 


\section{NYILVÁNOSSÁG A BÜNTETŐELJÁRÁSBAN: A JÁRVÁNYHELYZET EGY ÚJABB KÉRDÉSES PONTJA}

\section{Szerző:}

Németh János

Debreceni Egyetem

Szerző e-mail címe:

nemeth.janos97@gmail.com
Lektorok:

Prof. Dr. Elek Balázs

Debreceni Egyetem

Dr. Sipos Ferenc

Debreceni Egyetem

és további két anonim lektor...

\section{Absztrakt}

A COVID-19 járványhelyzet új kihívások elé állította a világ igazságszolgáltatási rendszereit. Jelentősen elterjedtek a távmeghallgatások a büntetőeljárásokban, és számos példa található az on-line bíróságok felé mutató gyakorlatra. A magyar jogalkalmazásban hangsúlyos szerephez jutnak a távmeghallgatások, de a jelenlegi körülmények között ugyancsak fontos szempont a tárgyalások nyilvánosságának biztosítása is.

Kulcsszavak: büntetőeljárás, nyilvánosság, igazságszolgáltatás, távmeghallgatás

Diszciplina: jogtudomány

\section{Abstract}

PUBLICITY IN CRIMINAL PROCEDURE:

AN OTHER PROBLEMATIC POINT OF THE PANDEMIC

The COVID-19 pandemic challenged the whole world's judicial systems. The use of remote hearings spread significantly in criminal proceedings, and there are also many examples hinting towards on-line courts. Remote hearings are a relevant part of the hungarian judicial system, but under the present circumstances, publicity of the trials is and important aspect as well.

Keywords: criminal procedure, publicity, jurisdiction, remote hearing

Discipline: jurisprudence

Németh János (2021): Nyilvánosság a büntetőeljárásban: a járványhelyzet egy újabb kérdéses pontja. Mesterséges intelligencia - interdiszciplináris folyóirat, III. évf. 2021/1. szám. 61-70. doi: 10.35406/MI.2021.1.61 
A 2020. tavaszán kihirdetett veszélyhelyzet során elrendelt szabályok nagy mértékben kihatottak a büntetőbíróság előtti távmeghallgatások alkalmazására. Ezek a változtatások olyan elméleti és gyakorlati kérdéseket is felvetettek, amelyek eddig is kérdésesek voltak a jogintézmény alkalmazása kapcsán: ilyenek voltak különösen a távmeghallgatás és a közvetlenség elvének kapcsolata, a tárgyalás pszichológiai tényezőinek változásai és az új eszközök alkalmazásához való hozzáállás az eljárásokban.

A távmeghallgatással kapcsolatos jogszabályi változások vizsgálata alapján is elmondható, hogy ezen technológiai újítás egyre széleskörűbb és gyakoribb alkalmazása kétségtelenül komoly - akár a digitalizációval, on-line bírósági eljárásokkal kapcsolatos - változások, s így a közvetlenséghez hasonlóan egyéb elvek újraértelmezésének előfutára is lehet a büntetőeljárásokban. Az ilyen jellegû további - pozitív - változások elősegítéséhez azonban az eddigi tapasztalatok, valamint a gyakorlat vizsgálata szükséges. Ezzel kapcsolatban pedig - s egyébként a büntetőeljárás egészére - igaznak vélem Richard Susskindnak (2020) az online ítélkezéssel és az esküdtszékekkel kapcsolatos véleményét: „elsősorban nem a technikát kell idomítani a megszokott eljárásrendhez, hanem inkább egyet hátra kell lépni, és megvizsgálni, hogy a megszokott gyakorlat milyen alapvető értékeket és elveket képvisel, milyen gyakorlati eredménye és előnye van, és hogy ezek vajon átültethetőek-, illetve javíthatóak-e új és eltérő eszközökkel egy digitális társadalomban." Véleményem szerint ilyen alapvető elv a közvetlenség mellett a nyílvános tárgyalás elve, melyet a járványhelyzet következtében a hazai jogrendszerben - a közvetlenséghez hasonlóan - új szabályok, a külföldi gyakorlatban pedig megfontolandó technikai megoldások helyeztek új megvilágításba. E tanulmány éppen ezért a magyar büntetőeljárásban érvényesülő nyilvánosságra vonatkozó törvényi szabályozás után a járványhelyzet hatására bekövetkezett változtatásokat ismerteti, s fogalmaz meg a hazai és külföldi megoldásokkal kapcsolatos gondolatokat, melyek a büntetőeljárás jövőjére tekintettel is relevánsak lehetnek.

\section{A büntetőeljárások nyilvánosságáról}

Magyarország Alaptörvénye (a továbbiakban: Alaptörvény) kimondja, hogy „,mindenkinek joga van ahhoz, hogy az ellene emelt bármely vádat vagy valamely perben a jogait és kötelezettségeit törvény által felállított, független és pártatlan bíróság tisztességes és nyilvános tárgyaláson, észszerű határidőn belül bírálja el" (XXVIII. cikk (1) bekezdés). A tárgyalás nyilvánosságának igénye tehát olyan alapvető követelménye a bíróság előtti eljárásoknak, melyet az Alaptörvény is szorosan együtt kezel a tisztességes eljárással, s így a büntetőeljárásokban is értelemszerűen érvényesülnie kell. A nyilvánosság már az 1840-es évek óta alapelve a bírósági eljárási szaknak (Antal, 2010), s a büntetőeljárásról szóló 2017. évi XC. törvény (a további- 
akban: Be.) a bíróság tárgyalását szintén nyilvános eljárási cselekményként aposztrofálja. Németh $(2019,58$ o. orávilágít arra, hogy „a nyilvánosság elsődlegesen a büntetőeljárás tárgyalási szakaszához köthető processzuális alapelv". Megfogalmazásában az ,a terhelt és az állam viszonyát szabályozza és elsődleges védelmet jelent a bírói önkény ellen, valamint tágabb értelemben garanciát nyújt a tisztességes eljárás megvalósulásának azzal, hogy biztosítja a büntetőeljárás átláthatóságát."

A büntetőeljárás meghatározott szakaszaiban lefolytatható egyéb eljárási cselekmények (így például a tanácsülés vagy a nyilvános ülés), valamint az eljárás különböző szakaszai (így például a nyomozati szak) más megítélés alá esnek. Egyébként pedig a bíróság előtti eljárási cselekmények esetében sem érvényesül kivétel nélkül a nyilvánosság: maga a Be. - annak 436-437. $\S$-aiban - is meghatároz olyan körülményeket, eseteket, amikor a jelenlevők létszámának, személyének korlátozására, esetleg a nyilvánosság teljes kizárására kerülhet sor: alapvető kikötés, hogy a tárgyaláson hallgatóként tizennegyedik életévét be nem töltött személy nem vehet részt, de az eljáró bíró a tizennyolcadik életévét be nem töltött személyt is kizárhatja a hallgatóság köréből, egyébként pedig meghatározhatja a hallgatóság létszámát a tárgyalás szabályszerû lefolytatása, méltóságának és biztonságának megőrzése érdekében, illetve helyszűke esetén. Hivatalból vagy indítványra teljeskörūen kizárhatja a nyilvánosságot az egész tárgyalásról vagy annak egy részéről, s ezzel együtt erkölcsi okból - jellemzően a nemi élet szabadsága és a nemi erkölcs elleni bűncselekmények esetén -, különleges bánásmódot igénylő személy védelme érdekében - például tanúvédelmi okból -, illetve minősített adat és egyéb védett adat - például üzleti titok - védelme érdekében zárt tárgyalást rendelhet el. Tanúvédelmi szempontból a tárgyaláson jelenlevők személyének meghatározása lényeges eszköz, a nyilvánosság, mint alkotmányos garancia pedig nem szolgálhat joggal való visszaélés alapjául, és nem lehet akadályozója annak, hogy a tanúk eleget tehessenek igazmondási kötelezettségüknek (Kúria Bfv.1200/ 2016/6.). Ilyen esetben figyelmezteti a jelenlévőket arra, hogy a tárgyaláson elhangzottakról tájékoztatást nem adhatnak, szükség esetén pedig a minősített adattal visszaélés büntetőjogi következményeire is. Fontos azonban, hogy a bíróság a zárt tárgyalás elrendelése esetén is engedélyezheti, hogy az igazságszolgáltatással összefüggő feladatokat ellátó hivatalos személyek a tárgyaláson jelen legyenek, külföldi állampolgár vádlott ellen, illetve a külföldi állampolgár sértett sérelmére elkövetett bűncselekmény miatt indult eljárás során pedig lehetővé kell tenni, hogy a tárgyaláson annak saját államának konzuli tisztviselője, illetve törvénnyel kihirdetett nemzetközi szerződés rendelkezése alapján a külföldi állam hatóságának tagja jelen lehessen. A minősített adat védelme érdekében történő elrendelés kivételével zárt tárgyalás elrendelése esetén a sértett, ha nincs képviselője, illetve a vádlott, ha nincs védője, indítványozhatja, hogy a tárgyalás 
helyszínén tartózkodó, általa megnevezett személy - ide nem értve a tárgyaláson kihallgatandó személyt - jelen legyen a tárgyaláson. Lényeges garanciális szabály továbbá, hogy a tárgyalást nyilvánosan kell folytatni, ha a zárt tárgyalás indoka megszűnt.

A nyilvánosság biztosításához szorosan kapcsolódik a tárgyalás rendjének és az eljárás méltóságának megőrzése is: az eljáró bíró - az egyesbíró vagy a tanács elnöke - a Be. 440. § (1)-(2) bekezdései alapján rendre utasítja és rendbírsággal sújthatja azt, aki a tárgyalás rendjét vagy szabályszerű menetét zavarja, ismételt vagy súlyos rendzavarás esetén pedig a rendzavarót kiutasíthatja, illetve kivezettetheti a tárgyalásról, valamint ,abban az esetben, ha a rendzavarás a hallgatóság körében merül fel, a bíróság az egész hallgatóságot kizárhatja anélkül, hogy vizsgálná, személy szerint ki és kik voltak azok, akik ismételten vagy súlyosan megzavarták a tárgyalás rendjét. Ebben az esetben nem zárt tárgyalást rendel el a bíróság, ilyen okra alapítottan nincs is helye a zárt tárgyalás elrendelésének. Előfordulhat azonban, hogy a különleges bánásmódot igénylő személy védelme érdekében azt követően dönt a zárt tárgyalásról, hogy a hallgatóság rendzavaró módon félemlíti meg az ilyen védettséget élvező eljárási szereplőt" (Elek, 2020). A Be. 439. § (3) bekezdése alapján az eljáró bíró gondoskodik a tárgyalás méltóságának megőrzéséről, s ennek érdekében köteles a tárgyalóteremből eltávolíttatni azokat, akik a tárgyalás méltóságát sértik. Ez azért is lényeges, mert - amint arra Elek (2020) rámutat -, a tárgyalás rendjének fentebb is ismertetett megsértése minden esetben sérti a tárgyalás méltóságát is, de ez utóbbit olyan magatartás is megvalósíthatja, amely egyébként nem minősül rendzavarásának, s így a rendzavarás következményeit sem lehet alkalmazni. Ezzel kapcsolatban kiemeli azt is, hogy „a tárgyalás méltóságának megsértésére alapított tárgyalásvezetési jogkör elsősorban a hallgatóságra vonatkozik, de alkalmazható tágabb körben, így a sajtó munkatársaira is. A tanács elnöke jogosult eldönteni, hogy milyen magatartás, viselkedés vagy megjelenés (például nem tárgyalóterembe illő öltözék) sérti a tárgyalás méltóságát” (Elek, 2020). Az eljárást vezető egyesbíró vagy tanácselnök számára tehát több lehetőség is kínálkozik a rendzavaró, az eljárás méltóságát sértő személlyel szemben, s nem jelent ezek alól mentesülést az sem, ha az a hallgatóság tagjaként, a nyilvánosság elvét érvényre juttatva van jelen az eljárási cselekmény helyszínén.

\section{A járványhelyzetben}

\section{bekövetkezett változások}

Jelen körülmények között a fent ismertetett, az eljárásban résztvevő személyének biztonságára, az eljárás rendjére és méltóságára vonatkozó igények mellett egy másik fontos szempont is előtérbe került: fokozott hangsúlyt kapott ugyanis a tárgyalótermek befogadóképességének és a tárgyaláson jelenlévő személyeknek, a hallgatóság létszámának, kérdése is, tekintettel a 
COVID-19 járvány elleni védekezésre. A jogalkotó a távolságtartás igényén túl megfogalmazott további megelőző rendelkezéseket is, melyek a büntetőeljárások nyílvánosságát is érintik. Ezeket a jelenleg hatályban lévő, a veszélyhelyzet megszűnésével összefüggő átmeneti szabályokról és a járványügyi készültségről szóló 2020. évi LVIII. törvény (a továbbiakban: Vmtv.) 204-205. §-ában szabályozza. Előbbiben kimondja, hogy hivatalból vagy indítványra meghatározhatja a bíróság a hallgatóság létszámát járványügyi intézkedés megtartása érdekében vagy egészségügyi válsághelyzettel összefüggő más okra figyelemmel. Ez tehát már kétségkívül magában foglalja a terem befogadóképességére vonatkozó létszámkorlátozást. A 205. § a nyilvánosság kizárásának lehetőségét tágítja ki azzal, hogy kimondja, a bíróság hivatalból kizárja a nyilvánosságot a tárgyalásról (vagy annak egy meghatározott részéről), amennyiben járványügyi intézkedésre vagy az egészségügyi válsághelyzettel összefüggő más rendelkezésre figyelemmel a bíróság a nyílvánosság számára nem látogatható. Amennyiben tehát járványügyi rendelkezésre tekintettel az adott bíróság épületébe csak meghatározott személyek léphetnek be, úgy célszerűen a hallgatóság sem vehet részt eljárási cselekményeken, mivel így értelmét vesztené a megelőző-védekező intézkedés is.

A Vmtv. 205. § (3) bekezdése alapján - a nyilvánosság érvényre juttatásának érdekében - ilyenkor a terhelt vagy a védő indítványára engedélyezni kell, hogy azok a náluk levő elektronikus eszközt bekapcsolva a tárgyaláson történteket rögzítsék. A bíróság a rögzítés engedélyezésekor figyelmezteti a terheltet a személyes adatok kezelésével összefüggő kötelezettségeire. A Vmtv. kimondja, hogy rögzítés nem engedélyezhető, ha a tárgyalásról a bíróság készít kép- és hangfelvételt, vagy a zárt tárgyalás elrendelésének törvényben meghatározott egyéb - akár a fentebb meghatározott bármely - okból van helye. A bíróság által készített kép- és hangfelvétel másolatát a tárgyalást követő nyolc napon belül az indítványt előterjesztő terhelt és a védő részére meg kell küldeni, vagy azt részükre hozzáférhetővé kell tenni. Fontos követelmény továbbá, hogy - összhangban a ténylegesen jelenlévő hallgatóságra vonatkozó szabályokkal - az eljáráson történtek ilyetén rögzítése nem járhat a tárgyalás rendjének, szabályszerű menetének zavarásával vagy a tárgyalás méltóságának sérelmével. Ilyen esetben ugyanis a bíróság megtiltja a rögzítés folytatását és a rendzavarás - ugyancsak fentebb hivatkozott következményeit alkalmazza. A jogalkotó továbbá rögzíti, hogy nem büntethető a Büntető Törvénykönyvrôl szóló 2012. évi C. törvény (a továbbiakban: Btk.) 280. §ának (2) bekezdésében szabályozott igazságszolgáltatással összefüggő titoksértés miatt az, aki az ilyen módon elrendelt zárt tárgyaláson elhangzottakat felfedi.

A jogalkotó által alkalmazott megoldás a gyakorlatban könnyedén megvalósítható, és valóban lehetőséget biztosít - akár sokkal szélesebb - nyilvánosság biztosításának, hiszen az így rögzített felvétel az inter- 
neten keresztül jelentősen nagyobb számú állampolgárhoz juthat el, mint amit egy tárgyalóterem befogadóképessége akár normális körülmények között is lehetővé tenne. Megfontolandó azonban az az eshetőség, hogy amint azt egy, a Pesti Központi Kerületi Bíróság előtt - a jelen tanulmány megírásának idejében - folyamatban lévő becsületsértés vétségének ügyében (B. 20773/2020) is történt, a járványügyi veszélyhelyzet miatt kizárt nyílvánosság okán rögzített tárgyalás akár olyan közismert médiatartalom-megosztó oldalakra (jelen esetben ez a YouTube) is felkerülhet, amit nap mint nap emberek milliói láthatnak. Kérdésessé válik ugyanis, hogy mennyire felel meg a nyilvánosság követelményének például egy, a szerkesztéshez, videóvágáshoz értő személy által saját szájíze szerint megvágott, s csak ezután közzétett felvétel. Nem is gondolva arra, hogy a közzétevő így esetleg valóban lényegi mozzanatokat, elhangzott részleteket hagy ki az eljárási cselekményből, úgy vélem, már magának a tárgyalás menetének, valósághű lefolyásának a megtörése is káros lehet. Amíg ugyanis lehetséges, hogy a hétköznapi ember egy vágatlan felvételt nem tekint vagy hallgat meg teljes egészében, hanem csak az ôt érdeklő részekhez „léptet”, még mindig megvan a lehetősége, hogy ha akar, minden mozzanatot figyelemmel kísérjen. Célszerűnek tartanám ezért, hogy egyértelmű jogszabályi követelmény legyen arra nézve, hogy a tárgyaláson rögzítetteket ilyenkor teljes egészükben nyilvánosságra kelljen bocsátani, s így a „hallgatóságra” bízni, hogy abból mire kíván valóban nagyobb figyelmet fordítani.

Az új szabályok elsősorban a nyilvánosság érvényesülésének korlátozásában figyelhetők meg, amit a fokozott járványügyi védekezés indokolt. A jogalkotó az ilyen okból kizárt nyilvánosságot az eljárási cselekményen optimális esetben résztvevő terhelt, illetve a védő kérelmére engedélyezett rögzítéssel igyekszik pótolni. Ez alól kivétel, ha az eljárási cselekmény egyébként is rögzítésre kerül, melynek tökéletes példája lehet egy távmeghallgatással tartott tárgyalás, ugyanis a Be. 125. § (2) bekezdése alapján - amennyiben jogszabály kivételt nem tesz - a telekommunikációs eszközzel továbbított felvételt mindig rögzíteni kell. Az eljárások folyamatos rögzítése, a tárgyalásokról készült felvétel nyilvánosan elérhetővé tétele kívánatos - s egyben a jelenlévő hallgatóságot szinte a legmegfelelőbben helyettesítő megoldásnak tủnhet, gondolva akár csak arra, hogy a nyilvánosságnak sokkal szélesebb körét érheti el, s még az a veszély sem fenyeget, hogy az eljárási cselekmény rendje, méltósága közvetlenül sérüljön. Ennél pedig már csak az élőben közvetített tárgyalások tűnhetnek ,jobb” megoldásnak. Habár a Vmtv. - a terhelt és a védô általi rögzítéssel kapcsolatban - már egyértelműen kiterjeszti azt a szabályozást, amit „a jogalkotó a klasszikus értelemben, kameraállványokkal és mikrofonokkal megjelenő sajtóorgánumok tárgyalóteremben való jelenlétére alkot" (Németh, 2019, 59. o.), továbbra is fennáll a kérdés, hogy „vajon a jogalkotó szándéka kiterjesztően 
értelmezve, magában foglalja a tárgyalásokon megvalósuló élő közvetítéseket is?" (Németh, 2019, U.o.) Véleményem szerint ilyen törekvésre egyelőre nem található utalás. A nyilvánosságnak ilyen mértékű kiterjesztése egyértelmű szabályozást igényel, mivel az nemcsak technikai, de alapjogi problémákat is magában hordoz: akár a terhelt, akár a védő, de akár csak a bíróság által rögzített felvétel élőben, on-line történő közvetítése esetén különös figyelmet kell szentelni azokra, akik megtagadhatják, hogy róluk felvétel készüljön. Ilyen tekintetben tehát gyakorlatilag visszatérünk a nyilvánosság korlátozására vonatkozó, az első fejezetben is ismertetett szabályokhoz: ugyanúgy érvényesülnie kell ugyanis a tanúvédelemre, erkölcsi szabályokra vagy titokvédelemre vonatkozó követelményeknek, különös tekintettel arra, hogy az interneten közvetített felvételt szinte bárki képes lehet rögzíteni, s a képernyő- vagy hangfelvételekkel, képernyőképekkel később visszaélni. Éppen ezért az esetleges on-line streaming megvalósításához átfogó, kógens szabályozásra lenne szükség mind annak technikai megvalósítását illetően, mind az eljárásban résztvevő személyek vonatkozásában, hiszen, amint egy rendkívül gyakorlatias példában Németh (2019, 60. o.) is rámutat, adott esetben a bíróság folyosóján várakozó, kihallgatás előtt álló tanú is használhatná a saját mobiltelefonját, vagy más elektronikus eszközét, s ezen nyomon követhetné akár az ajtó túloldalán folyamatban lévő tárgyalásról szóló élő közvetítést is.

\section{Kanadai és amerikai megoldások}

A tárgyaláson történtek rögzítése és közzététele a médiaszolgáltatók közvetítése útján - a nyilvánoság tájékoztatására vonatkozó szabályokra is figyelemmel eddig is megvalósulhatott, a vádlott vagy védője általi rögzítés mégis új megoldás, s nem szorítkozik csak olyan esetekre, amit előbbiek is hírértékűnek minősítenek. Az azonban kétségtelen, hogy a valós időben jelenlevő nyilvánosságot ez sem képes pótolni. A kérdés így az lehet, hogy van-e más reális megoldási lehetőség? A nemzetközi gyakorlatot figyelembe véve erre a kérdésre igenlő válasz adható: a nyilvánosság digitális biztosítására (távmeghallgatás igénybevételével tartott eljárási cselekmények esetén) ugyanis egyre több külföldi példa áll rendelkezésére.

Schmitz (2020) beszámol arról, hogy távmeghallgatással tartott tárgyalásokat a nyílvánosság számára online közvetítenek a kanadai Legfelsőbb Bíróság honlapján, de újításként már a Zoom platformon is nyomon követhetőek az események, ahol - a weboldalon közvetített adással ellentétben - nem csak a beszélőt látja a néző, hanem az szabadon váltogathatja a kameraképet, így akár egy-egy kiválasztott, de akár minden az eljárásban résztvevő személyt egyszerre is figyelhet. Egyébként az eljárás résztvevői is a Zoom platformot használják, azzal a különbséggel, hogy - értelemszerűen - a hallgatósággal ellentétben nekik a mikrofon- és kamerafunkciók is rendelkezésükre állnak.

Washington állam bíróságai külön honlapon biztosítanak lehetőséget az egyébként 
ugyanott élőben közvetített virtuálisan zajló eljárási cselekmények utólagos megtekintésére is. A későbbi megtekintéshez, az elhangzottak nyomon követéséhez segítséget nyújt a videók alatt megtalálható (automatikusan, számítógép által generált) szövegátirat, mely az írásban így rögzített felszólalások kezdetét időbélyegzővel jelöli, s így segíti a visszakereshetőséget. Ilyen, visszanézhető bíróság előtti eljárásokra példa a tavaly októberben a State of Washington v. Cory Pratt (Net2), novemberben a State of Washington v. Tanner Lee Coryell (Net3), vagy az idén január 21én, a State of Washington v. Lynell Avery Denham (Net1) ügyben lefolytatott eljárási cselekmények.

\section{Konklúziók}

A távmeghallgatásokkal kapcsolatos külföldi joggyakorlat és a hazai szabályozás vizsgálata a technológiai újításokkal kapcsolatban egy másik alapvető követelmény, a nyilvánosság érvényesülésének új kérdéseire mutatott rá. „A nyilvánosság elve, mint a büntetőeljárás általános processzuális alapelve, garanciát jelent az eljárási résztvevők számára, hogy a bíróság pártatlanul és függetlenül járjon el, továbbá az eljárási jogok megfelelő gyakorlása is ellenőrizhetô általa" (Varga, 2018, 90. o.). A nyilvánosság érvényre juttatása eljárásjogi garancia, s így nem az állampolgárok szórakozását hivatott biztosítani. A tárgyalások személyes jelenléten alapuló figyelemmel kísérésének mindenképpen lehetőséget kell biztosítani, de az nem szolgálhat az eljárások rendezett és méltóságteljes lefolytatásának akadályául. Éppen ezért a bíróságnak jogot kell biztosítani arra, hogy a tárgyalás rendjének, méltóságteljes lefolytatásának érdekében korlátozhassa a jelenlévők körét. Ugyancsak nyilvánvaló, hogy egy - a jelenlegihez hasonló - járványhelyzet esetén sem állhat az emberek egészségének, testi épségének védelme elébe a nyilvánosság biztosítása a tárgyaláson, amennyiben az ténylegesen személyes jelenléttel valósul meg. Már pedig a hazai jogrendszerben egyelőre csak a személyesen megjelenő hallgatóság követheti nyomon valós időben a tárgyalóteremben történteket. Az ott történtek közvetítésével, rögzítésével kapcsolatban „A jogalkotó a klasszikus értelemben, kameraállványokkal és mikrofonokkal megjelenő sajtóorgánumok tárgyalóteremben való jelenlétére alkot szabályokat." (Németh, 2019, 59. o.). A jelenlegi helyzetben pedig éppen ezért még aktuálisabb a kérdés, hogy „,vajon milyen rendelkezéseket kell alkalmazni abban az esetben, ha valamely sajtószerv képviselője, vagy akár bármelyik magánszemély a mobiltelefonjával, a tárgyalással egy időben, élő-közvetítés (online-streaming) formájában tájékoztatja a társadalom szélesebb körét a büntetőeljárás menetéről?" (Németh, 2019, u. o.). Ugyancsak hangsúlyosnak tartom a felvett anyag későbbi közzétételének mikéntjére vonatkozó átfogó szabályanyag kidolgozását, így a) - amint arra a 2. fejezetben is utaltam -, akár arra nézve írni elő kötelezettséget, hogy az eljárási cselekményen rögzítetteket - természetesen minden 
más eljárási garanciának megfelelően - teljes egészükben, vágatlanul legyen köteles a közzétevő nyilvánosságra hozni, vagy akár b) egységesen, a bíróság általi rögzítést biztosítani, s az így felvett anyagot erre rendszeresített felületen - például internetes honlapon - közzétenni, ezzel is garantálva annak valósághű és teljes voltát.

Az nemzetközi példákból jól látható, hogy bizonyos esetekben akár büntetőeljárásokban távmeghallgatás alkalmazásával tartott eljárási cselekmények esetén is lehetséges egyúttal valós időben (de akár későbbi megtekintés lehetőségét biztosítva rögzítve is) a világhálón hozzáférhetővé tenni az ott elhangzottakat, ezzel biztosítva széles körű nyilvánosságot akár olyan ügyekben is, amikor az eljáró bírón - vagy bírói tanács tagjain - kívül más nem is tartózkodik a bíróság épületében. Mindenképpen szükséges lenne azonban a részletekre kiterjedően szabályozni egy hasonló rendszer alkalmazását abban az esetben, ha azt ténylegesen igénybe kívánná venni a hazai jogalkalmazás. Nem kívánatos ugyanis, hogy elsietett félmegoldások akár alapvető jogok tömeges sérelmét eredményezzék.

Susskind (2020) szerint a bíróságoknak is gondolkodásmódbeli változásra van szükségük ahhoz, hogy a járványhelyzet miatt bekövetkezett újításokat megfelelően tudják kezelni. Az eddigiekben bekövetkezett változtatások szerinte azonban nem az átalakulást - a rendes bírósági eljárásoknak az online bíróságokká történő fejlődését vetítik előre, hanem szimplán automatizációt sejtetnek, a jelenlegi ítélkezési rendszernek a Zoom platformra történô „behajítása” pedig nem tekinthető tényleges paradigmaváltásnak. A nemzetközi gyakorlatban alkalmazott megoldásokat megfontolandónak tartom, nem feledkezve meg arról, hogy büntetőeljárások esetében fokozott figyelmet kell fordítani más eljárásjogi garanciáknak, az eljárásban részt vevő személyek alapvető jogainak, testi épségének védelmére is. Mindemellett úgy vélem, a távmeghallgatások egyre gyakoribb alkalmazása során az ilyen módon megvalósított eljárási cselekményeken a nyílvánosság biztosítására vonatkozó külföldi gyakorlat akár a hazai jogalkotásra is hatással lehet, mely a jelenlegi helyzetben, de a jövőben is, nagyban hozzájárulhatna az eljárások nyugodt körülmények között zajló, s mégis valós időben történő figyelemmel kíséréséhez. Ha ez így történne, kétségkívül egy hatalmas lépéssel közelebb kerülnénk az on-line bírósági eljárások megvalósulásához, még ha ez számos további elméleti és gyakorlati kérdést is vetne fel.

\section{Irodalom}

2017. évi XC. törvény a büntetóeljárásról 2017. évi XC. törvény Miniszteri Indokolása Antal, D. (2010). A nyilvánosság és a büntetőeljárás. Studia iuvenum iurisperitorum, 2010/5, 219-239.

Elek, B. (2020). A Be. 439-440. 』-ához in.: Polt Péter (szerk.) (2020) Kommentár a büntetöeljárásról szóló 2017. évi XC. törvényhez, Wolters Kluwer Hungary Kft., Budapest, On-line elérhető változat Web: 
https://uj.jogtar.hu/\#doc/db/396/id /A17Y0090.KK/ts/20200701/lr/chai n6699/ (megtekintve: 2020. 02. 10., A kommentár utolsó időállapota: 2020. július 1.)

Kúria Bfu.1200/2016/6.

Magyarország Alaptörvénye

Németh, K (2019). A büntetőeljárás nyilvánosságának jogszabályi hátterében húzódó alapjogi kollíziók feltárása, különös tekintettel az ágazati titokvédelemre. Debreceni Jogi Mühely (XVI. évfolyam) 2019/1-2, 55-76. DOI 10.24169/DJM/2019/1-2/5

Net1: State of Washington v. Lynell Avery Denham, Washington State Supreme Court, January 21, 9:00 am, Web: https://www.tvw.org/watch/?clientI $\mathrm{D}=9375922947$ \&eventID $=202101124$ 8\&autoStartStream $=$ true (megtekintve: 2020. február 3.)

Net2: State of Washington v. Cory Pratt, Washington State Supreme Court, Oct. 20, 2020 - 10:00 am Web: https://www.tvw.org/watch/?clientI $\mathrm{D}=9375922947$ \&eventID $=202010111$
2\&autoStartStream $=$ true (megtekintve: 2020. február 3.) Net3: State of Washington v. Tanner Lee Coryell, Washington State Supreme Court, Nov. 10, 2020 - 1:30 pm, Web: https://www.tvw.org/watch/?clientI $\mathrm{D}=9375922947$ \&eventID=202011104 2\&autoStartStream $=$ true (megtekintve: 2020. február 3.)

Schmitz, C. (2020). SCC poised for first virtual appeal hearing; Zoom 'observers' to see novel contract, criminal cases Web: https://www.thelawyersdaily.ca/articl es/19410/scc-poised-for-first-virtualappeal-hearing-zoom-observers-tosee-novel-contract-criminalcases? category $=$ news (megtekintve: 2020. október 23.)

Susskind, R. (2020). The Future of Courts, The Practice, 2020/5

Varga, P. (2018). A nyilvánosság elvének érvényesülése a büntetőeljárásban, Debreceni Jogi Mühely (XV. évfolyam) 2018/ 1-2. 76-92. o. DOI 10.24169/DJM/2018/1-2/9 
MÓDSZERTANI TANULMÁNYOK 


\title{
CSÍPŐPROTÉZISEK BERÖGZÜLÉSÉNEK ÉS ÉLETTARTAMÁNAK OPTIMALIZÁLÁSI LEHETŐSÉGE FÉMNYOMTATÁS ÉS MESTERSÉGES INTELLIGENCIA SEGÍTSÉGÉVEL
}

\section{Szerző:}

Szabó Dániel

Magyarország

Szerző e-mail címe:

szabo.danie1995@gmail.com
Lektorok:

Mező Ferenc (PhD)

Eszterházy Károly Egyetem

Mező Katalin $(\mathrm{PhD})$

Debreceni Egyetem

...és további két anonim lektor

\begin{abstract}
Absztrakt
Manapság egyre fiatalabb korosztályok részéről támad igény csípőprotézis beültetésére, azonban a napjainkban alkalmazott csípőprotézisek élettartama véges, amiben fontos szerepet játszik a protézisek kilazulása. Orvosbiológiai kutatások feltárták, hogy a csontszövet képes egy lyukacsos fogadófelületbe belenőni, biológiai kapcsolódást létrehozva azzal, ilyen szerkezeteket pedig a korunkban elérhető additív technológiák segítségével létre tudhatunk hozni. A tanulmány célja egy lehetséges irányt felvázolni az implantátumokat alkotó, additívan gyártható, lyukacsos szerkezetek belső struktúrája, és a szerkezetek mechanikai tulajdonságai között fennálló összefüggések feltárására, és a szerkezetek optimalizálására.
\end{abstract}

Kulcsszavak: csípőprotézis, élettartam növelés, additív technológiák, fémnyomtatás, mechanikai tulajdonságok, mesterséges intelligencia

Diszciplina: orvostudományok, műszaki tudományok, informatikai tudományok, matematikai tudományok

\footnotetext{
Abstract

OPTIMIZATION POSSIBILITY OF THE FIXATION AND LIFESPAN OF HIP PROSTHESES WITH THE USE OF METAL ADDITIVE MANUFACTURING AND ARTIFICIAL INTELLIGENCE

Nowadays, there is a demand for hip implants by younger and younger age groups, but the lifespan of the hip prostheses used today is finite, in which the loosening of prostheses plays an important role. Biomedical research has revealed that bone tissue can
} 
infiltrate a porous receiving surface, creating a biological connection with it, and such structures can be created using additive technologies available in our time. The aim of this study is to outline a possible direction for exploring the connection between the internal structure, and the mechanical properties of additively manufacturable porous structures, and the possibilities of their optimization.

Keywords: hip implant, additive technologies, metal additive manufacturing, lifespan elongation, mechanical properties, artificial intelligence

Disciplines: medicine, engineering, informatics, mathematics

Szabó Dániel (2021): Csípőprotézisek berögzülésének és élettartamának optimalizálási lehetősége fémnyomtatás és mesterséges intelligencia segítségével. Mesterséges intelligencia interdiszciplináris folyóirat, III. évf. 2021/1. szám. 73-85. doi: 10.35406/MI.2021.1.73

A leggyakoribb felnőttkori csípőbetegségek az ízületi kopás, és a csontelhalás jelenségekre vezethetôk vissza. Az ízületi kopás egy természetes folyamat, melynek során az idő előre haladtával a csontok végét borító porc károsodik, a csont elhalás folyamata során pedig vérellátási zavarból kifolyólag felpuhul a porc alatti csontvég, majd idôvel beszakad (Net1). A pácienseknél ezen problémák állandósult fájdalom és mozgáskorlátozottság formájában szoktak jelentkezni, és ez esetben az orvosok általában protézis beültetését javasolják (Net2). A beavatkozás iránt egyre fiatalabb korosztályok részéről támad igény, a hagyományos implantátumok élettartama viszont véges. Amikor egy implantátum tönkremegy, revíziós mútétet szükséges végrehajtani, mely az eredeti mútétnél megterhelőbb a beteg számára, így felmerült az igény új típusú, hosszabb élettartammal rendelkező protézisek kifejlesztése iránt. A legrégebben alkalmazott implantátumok egy tömör szárral kerülnek beépítésre a combcsontba, cementes rögzí- téssel (Net3). Ezen implantátumoknál gyakran megfigyelhető az a jelenség, hogy az implantátum átveszi a terhelést a környező csontszövetekről, melyekben idővel így csontritkulás alakul ki, és ez végül az implantátum kilazulásához vezet (Huiskes, 1993). Kutatások kimutatták, hogy a csontszövet képes belenőni egy meghatározott méretű pórusokkal rendelkező fogadófelületbe (Naoya és tsai, 2016), amit hogyha sikerül a csípőimplantátumoknál alkalmazni, megoldható lehet a kilazulás problémája. Ezen ismeretek alapján kifejlesztésre kerültek különféle porózus bevonatokkal ellátott protézis szárak, amelyek nagymértékben javítottak a berögzülésen, ugyanakkor több probléma is felmerült velük kapcsolatban, úgymint a nem egységes pórusméret, az esetenként túl vékony rétegvastagság, vagy a bevonat bizonyos idô utáni károsodása, leválása. (Ibrahim és tsai, 2015) Napjainkban már elérhetővé vált a fémnyomtatás technológiája kellően finom gyártási pontossággal, melynek segítségével akár 
egész protézisek legyárthatók lehetnek egy darabban, tervezhető, meghatározott nagyságú pórusokkal, az ezzel készített implantátumok pedig felválthatják az utólagos bevonattal ellátott protéziseket. A tanulmányban bemutatásra kerül, hogy napjainkban milyen 3D fémnyomtatási eljárások léteznek, és azokat milyen célokra, milyen eredményekkel használták fel eddig, majd bemutatásra kerül néhány 3D tervezőprogram segítségével létrehozott, fémnyomtatással legyártható, lyukacsos próbatest, és felvázolásra kerül egy irány, melynek segítségével kategorizálni lehetne mesterséges intelligencia segítségével, hogy a szerkezet belső kialakításának változtatása milyen hatással van a szerkezet mechanikai tulajdonságaira, ami által optimalizálni lehetne az implantátumok élettartamát.

A tanulmány alapját részben egy korábbi, saját TDK dolgozat képezi, melyhez különböző gondolatok kerültek hozzákapcsolásra.

\section{Additív megmunkálás}

1981-ben a Texasi Egyetem Műszaki Karán Carl Deckard, Joe Beaman és Paul Forderhase kifejlesztették a Szelektív Lézer Szinterezés folyamatát. Az általuk létrehozott eljárás számítógéppel vezérelt lézersugarakat használt por állapotú részecskék rétegenként történő egymásba olvasztásához. Hármójuk munkája alapján, és a kifinomult számítógépes tervező programok (3D CAD) létrejöttével megszületett az Additív Megmunkálás iparágazata. Az AM korunkban még egy új technológia, megjelenése az elmúlt 30 évre vetítve nagy áttörésnek számít a megmunkálási technológiák területén. Az anyagfelhalmozás módszerén alapszik, a komponensek fokozatos anyaghozzáadással, rétegről rétegre készülnek el az eljárás során (Lian és tsai, 2017; Bill és tsai, 2015).

A technológia az elmúlt 20 évben nagyon gyorsan fejlődött, és mára már több eljárást is magába foglal, mint például a Gyors Prototípuskészítés, a Szabadformájú Szilárdtest Gyártás, vagy a 3D Nyomtatás. Az AM manapság fokozatosan kezd a legfőbb megmunkálási technológiává válni, folyamatosan növekvő sikere a hagyományos megmunkálási módokhoz képest mutatott előnyeinek tudható be, mint például a nagyobb szabadság nyújtása az innovatív tervezés számára, a strukturális komplexitás lehetősége anyagi többlet terhek nélkül kis méretekben is, a szerszámköltségek potenciális eliminálása, a közvetlen megmunkálási folyamat öntőformák nélkül, a gyártási folyamatok lépéseinek eliminálása, vagy a környezetbarátság. A technológia előnyeit jelenleg ellensúlyozza a lassú gyártási folyamat, a magas alapanyagköltség, a limitált komponens méret, a maradó feszültségek kiszámíthatatlansága, és az esetleges utókezelések szükségessége (Krawczak, 2015; Thomas és tsai, 2016; Kumar és tsai, 2015).

A technológia folyamatos fejlődésével kiterjed több különböző területen belüli alkalmazásra is, és tökéletesen beilleszkedik a numerikus tervezés és a gyártási folyamatok láncába. A Gyors Prototípuskészítési technológiák fejlődése miatt lehetségessé vált sorozatgyártás előtt mintadarabok létrehozása nagyon rövid idő alatt. A Mérnöki Visszafejtéssel 
együtt nagyon jól kiegészítik egymást munkadarabok javításában, vagy reprodukciójában. Az elmúlt években a repülőgépgyártás, az autóipar, és az orvosi felhasználás voltak a technológia elsődleges húzóágazatai (Gardan, 2016). A technológia segítségével létrehozhatók prototípusok, kreatív bemutatódarabok, személyre szabott, egyedi használati tárgyak, vagy egyedi tulajdonságokkal bíró orvosi implantátumok is.

A fémek megmunkálására alkalmas AM technológiák elsődleges alkalmazási területei és húzóágazatai a repülőgépgyártás, az olaj és gázipar, a hajóipar, és az autóipar, de a technológia ígéretesnek bizonyul az ortopédiai implantátumok gyártásának területén is.

Bármilyen fémnyomtatás esetén a procedúra két legfőbb paramétere az, hogy milyen nyersanyagból, és milyen energiaforrás segítségével hozzuk létre a terméket. A felhasznált nyersanyag lehet fémpor, vagy huzal. Huzal alapanyag esetén lézer/elektronsugár, vagy ív is használható energiaforrásként. A fémnyomtatásra alkalmazható AM technológiák három fô csoportja a Porágyfúzió (PBF) alapú technológiák, az Irányított Energiaközlés (DED) alapú technológiák, melyek tovább bonthatók a felhasznált energiaforrás alapján, és a sugaras (JET) technológiák (lásd: 1. táblázat - Szabó, 2018).

A porágyfúzió alapú technológiák esetén minden egyes porréteg szelektíven kerül fuzionálásra egy energiaforrás, például lézer segítségével. Ezek a legígéretesebbnek tûnő $\mathrm{AM}$ technológiák kisméretű, kis darabszámú, komplex, fémes munkadarabok gyártásához.
1. táblázat: fémnyomtatási eljárások csoportositása (forrás: a Szerzoó)

\begin{tabular}{|c|c|c|}
\hline $\begin{array}{c}\text { Porágyfúzió } \\
\text { (PBF) }\end{array}$ & $\begin{array}{l}\text { Irányított } \\
\text { energia- } \\
\text { közlés } \\
\text { (DED) }\end{array}$ & $\begin{array}{l}\text { Sugaras } \\
\text { technoló- } \\
\text { giák (JET) }\end{array}$ \\
\hline $\begin{array}{l}\text { Szelektív lézer } \\
\text { szinterezés/olvas } \\
\text { ztás (SLS/SLM) }\end{array}$ & $\begin{array}{l}\text { Mérnöki } \\
\text { lézeres } \\
\text { hálózás } \\
\text { (LENS) }\end{array}$ & \multirow{3}{*}{$\begin{array}{c}3 \text { dimenziós } \\
\text { nyomtatás } \\
\text { (3DP) }\end{array}$} \\
\hline $\begin{array}{l}\text { Fém direkt lézer } \\
\text { szinterezés } \\
\text { (DMLS) }\end{array}$ & \multirow{2}{*}{$\begin{array}{l}\text { Irányított } \\
\text { fémlerakás } \\
\text { (DMD) }\end{array}$} & \\
\hline $\begin{array}{l}\text { Elektronsugaras } \\
\text { olvasztás (EBM) }\end{array}$ & & \\
\hline
\end{tabular}

Szelektiv lézer szinterezéssel (Singh és tsai, 2017; Olakanmi és tsai, 2015) könnyűszerkezetű, porózus struktúrák gyárthatók. Ezeknél lehetséges a végtermék súlycsökkentése a várható igénybevételre való tervezéssel, így tovább csökkenthető az alapanyag-szükséglet, illetve a mérgező kemikáliák és hűtőanyagok felhasználása is (Buchbinder és tsai, 2012; Cooper és tsai, 2012). A technológiának természetesen hátulütői is vannak. Egy ilyen eljárással készült terméknek rossz a felületi minôsége, az alaki pontossága, és az anyagi tulajdonságai (mikrostruktúra és mechanikai tulajdonságok). Az ilyen jellegű elvárásokban egy SLM technológiával készült termék nem teljesíti az ipari felhasználhatósághoz szükséges elvárásokat. Ezen hátrányok kiküszöbölésére utókezelések (polírozás, festés, hőkezelés (Net4)) alkalmazása szükséges, de ezzel a gyártási folyamat 
meghosszabbodik, és annak költségei növekednek. A 2000-es évek elején kutatásokat végeztek porózus biomedikai struktúrák létrehozására, melyek során szempont volt az elégséges mechanikai tulajdonságok megtartása. Egy tanulmányban porózus SS-316L anyagot készítettek SLS technológiával. Az eredményeik szerint 1100-1300 fok közötti hőmérsékleten szinterezés után a termékek mechanikai tulajdonságai nagyban javultak. Felismerték, hogy a mikroszerkezeti paraméterek és a mechanikai tulajdonságok a szivacsos csontszerkezet tulajdonságaihoz hasonlóra állíthatók optimalizált gyártási paraméterekkel, és a szinterezési hőmérséklet megfelelő beállításával (Singh és tsai, 2017; Xie és tsai, 2013). Kiderült az is, hogy az SLS technológiával gyártott, megerősített kompozit bio-elemek kristályosak, bioaktívak és oszteokonduktívak, melyek nagyon kedvező tulajdonságok a csontbenövés elősegítéséhez (Singh és tsai, 2017; Xiaohui és tsai, 2015). Az SLS/SLM technológiát már többen alkalmazták orvosi felhasználású implantátumok létrehozására (Stoodley és társa, 1996; Hayashi és társai, 2005). A technológiával 20 mikrométeres rétegvastagság is elérhető. (Net5)

A fém direkt lézer szinterezés fémport, és egy nagy energiájú lézert használ, hogy szinterezés útján létrehozzon egy terméket. Az eljárás nagymértékben hasonlít az SLS/SLM technológiákhoz, de eltérő technológiai paraméterekkel üzemel. Az SLS/SLM polimereket, vagy bevonatos fémporokat, míg a DMLS bevonatmentes, előre ötvözött fémporokat használ a szinterezés alapanyagaként. Egy egyedi Ti-6Al-4V ötvözetből, DMLS eljárással készült kondiláris lemez geometriájának megvizsgálták a mechanikai szilárdságát és pontosságát szakítószilárdság és mikro-keménységmérésekkel, illetve ANSYS szoftverrel is. Az eredmények azt mutatták, hogy a DMLS technológia széles körben alkalmazható koponya és állcsont implantátumok készítéséhez az eljárás során elérhető kedvező mechanikai tulajdonságok miatt. Egy további képfeldolgozó szoftver igazolta az eljárás alkalmazhatóságát emberi állcsontokban is (Singh és tsai, 2017; Gregolin és tsai, 2013). Állatkísérleteket végeztek nyulakon, melyek azt mutatták, hogy azok combcsontjába beépítve az állati csontszövet behatolt az implantátum pórusaiba, és közvetlenül hozzákötött annak falaihoz 12 héten belül (Singh és tsai, 2017). Egy tanulmányban DMLS procedúrával készült, Ti-6Al-4V termékeken végeztek maradó feszültségre vonatkozó vizsgálatokat. A termékek EOSINT M280 géppel készültek az EOS által javasolt gyártási paraméterek használatával. A maradó feszültségeket elemezték, megvizsgálták a mikrostruktúrát, illetve a fö feszültségek nagyságát és irányát is. Arra az eredményre jutottak, hogy gyártás után az xy síkban kéttengelyű húzófeszültségek maradtak vissza, és a fő komponens a szkennelési iránynyal egytengelyű volt (Zyl és tsai, 2016). A technológiával akár 20 mikrométeres rétegvastagság, és 250x250x325 mm nagyságú munkatér méret is elérhető. (Net6)

$\mathrm{Az}$ elektronsugaras olvasztás egy nagy energiájú elektronsugarat használ energiaforrásként, melyre kiemelkedő pontosság és nagy olvasztóképesség jellemző, ami nagy produktivitást eredményez. Egy tanulmányban új- 
szerű, celluláris Ti-6Al-4V struktúrákat készítettek ortopédiai felhasználásra EBM technológiával. Számítógépes tesztek eredményeképp demonstrálták, hogy az EBM technológia alkalmas összekapcsolt porozitással rendelkező 3D struktúrák létrehozására. Ez a szerkezet alkalmas szövet benövesztésre és eresítésre (Singh és tsai, 2017; Heinl és tsai, 2008). Egy tanulmányban Ti-24Nb-4Zr-8Sn komponenseket készítettek maximum 70\% porozitással, és öregítő eljárásnak tették ki óket. Az ilyen anyagból, EBM eljárással készített komponensek körülbelül kétszeres erőmodulusz arányt mutattak Ti-6Al-4V anyagból készült komponensekhez képest, azonos porozitás mellett. A technológiával 20 mikrométeres rétegvastagság érhető el. (Singh és tsai, 2017; Liu és tsai, 2016; Szabó, 2018).

Az irányitott energiaköolés alapú technológia egy komplex nyomtatási folyamat, melyet általában javításokhoz, vagy meglévő alkatrészekhez való anyaghozzáadáshoz használnak. A DED a fémmegmunkálásban kevésbé terjedt el teljes termékek AM-jéhez, elsősorban a kisebb pontosság és a szükséges utómegmunkálások miatt.

A mérnöki lézeres hálóáast azért fejlesztették ki, hogy fém alkatrészeket tudjanak segítségével gyártani közvetlenül a CAD modellek alapján. Az eljárás során fémport juttatnak egy olvadt medencébe, illetve a javítani kívánt munkadarab nagy energiájú lézersugár segítségével megolvasztott felületébe (Julien, 2016). A többi, por ágyat használó technológiához képest lényegesen nagyobb méretű munkadarabokat lehet legyártani az eljárás segítségével (Net7). Egy tanulmányban Ti-TiO2 alapú új struktúrákat készítettek funkcionális osztályozás útján LENS technológia alkalmazásával. Ezek a funkcionálisan osztályozott struktúrák változó TiO2 kerámia koncentrátumot tartalmazva biokompatiblisnek, és nem mérgezőnek bizonyultak, illetve javították a keménységét, felületi nedvesítőképességét és formációját a kemiszorbeált kenőanyag filmeknek. Ezek az egységesített struktúrák egyik felületükön nyílt porozitással, a másikon alacsony súrlódással megszüntethetik a tehertartó implantátumok többféle anyagból, több komponensből történő felépítésének szükségességét, például teljes csípő protézisek esetén (Singh és tsai, 2017; Balla és tsai, 2009).

Az irányitott fémlerakás egy fémpor injektáló rendszeren alapul, melyhez egy szálas lézer társul egy robotkaron. A folyamat rendkívül hasonlít az FDM technológiához, mert a fúvóka mozgás közben helyezi le az olvasztott fémet (Net8). A DMD nagyon jól használható meglévő szerszámok javításához, már meglévő nagy munkadarabokhoz további részek építéséhez, vagy akár új termékek létrehozásához is. Elsősorban a repüléstechnikában alkalmazzák komplex és drága részegységek javításához azok pótlása helyett (Szabó, 2018).

A 3 dimenziós nyomtatás segítségével fém munkadarabok is gyárthatók. Az eljárás során az elérhető rétegvastagság kb. 90 
mikrométer. A Prometal egy 3D nyomtatási folyamat, mely rozsdamentes acélporból dolgozik. A nyomtatási folyamat során egy folyékony kötőanyagot lövellnek sugarakban az acélporra. A folyamat végén szükséges egy utókezelés, ennek során szilárdul meg teljesen az anyag. A Digital Metal ${ }^{\mathrm{TM}}$ egy precíziós tintasugaras technológia, amit a Svéd Fcubib AB fejlesztett ki, mely 3DP eljárással hoz létre mikro fém komponenseket $20 \mu \mathrm{m}$ felbontásban, és kb. $4 \mu \mathrm{m}$ felületi érdességgel (Johander és tsai, 2007; Johander és tsai, 2005; Szabó, 2018).

Az irodalomkutatás alapján az EBM, és a DMLS technológia segítségével egyaránt készítettek már orvosi implantátumokat, ezen technológiák ígéretesnek bizonyul-hatnak ortopédiai alkalmazásra (Szabó, 2018).
Az EBM eljárással általában kisebb méretú munkadarabok készíthetők, míg a DMLS technológia munkaterének mérete alkalmas lehet akár egy teljes csípőprotézis egy darabban történő legyártására is.

\section{Próbatest minták}

A tanulmányhoz szabványos próbatest modellek készültek (lásd: 1. ábra). A próbatestek egységcellákból, többféle kialakításban, az ISO 13314 szabvány (Net9) és az orvosbiológiai elvárások alapján lettek létrehozva nyomóvizsgálatok végzéséhez. Mindhárom próbatest $10 \mathrm{~mm}$ átmérōjü, és $\mathrm{kb} .15 \mathrm{~mm}$ magasságú henger, ezek közül kettő eltérő kocka egységcellákból, egy pedig oktaéder egységcellákból lett felépítve (lásd: 2. táblázat).

1. ábra: $A, B, C$ próbatestek. (forrás: a Szerzố)
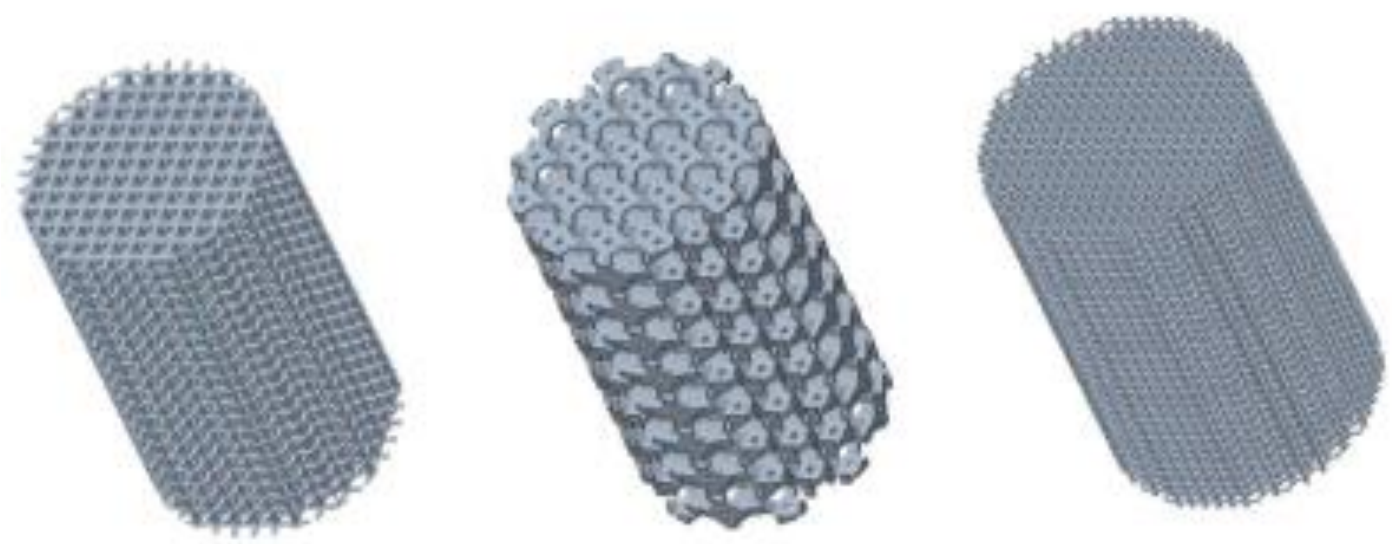
2. táblázat: a próbatestek adatai. (forrás: a Szerzó)

\begin{tabular}{|l|l|l|l|}
\hline \multicolumn{4}{|c|}{ A próbatestek adatai } \\
\hline Megnevezés & Próbatest A & Próbatest B & Próbatest C \\
\hline Egységcella típusa & Kocka & Oktaéder & Kocka \\
\hline Befoglaló méret & $0,8^{*} 0,8^{*} 0,8 \mathrm{~mm}$ & $2 * 2^{*} 2 \mathrm{~mm}$ & $0,5^{*} 0,5^{*} 0,5 \mathrm{~mm}$ \\
\hline Gerendavastagság & $0,2 \mathrm{~mm}$ & $0,4 \mathrm{~mm}$ & $0,1 \mathrm{~mm}$ \\
\hline
\end{tabular}

A próbatestek anyagtulajdonságinak meghatározása során nagyon fontos figyelmet fordítani arra, hogy humán felhasználásra csak biokompatiblis, nem mágnesezhető anyagok alkalmazhatók, ilyen például a DMLS eljárásban használható titán ötvözet (Ti-6Al-4V) (lásd: 3. táblázat), az egységcellák tervezése során pedig figyelembe kell venni, hogy a csont benövéséhez a 600 mikronos pórusméret a legoptimálisabb (Wang és tsai, 2017).

\section{3. táblázat: a titán ötvözet anyagtulajdonságai} (forrás: Mankovits, 2018 alapján a Szerzó)

\begin{tabular}{|l|c|}
\hline \multicolumn{2}{|c|}{ Az alapanyag tulajdonságai } \\
\hline Anyagtípus & Titán ötvözet \\
\hline Jelölés & Ti6Al4V \\
\hline Szakítószilárdság & $1075 \mathrm{MPa}$ \\
\hline Folyáshatár & $965 \mathrm{MPa}$ \\
\hline Rugalmassági modulusz & $114,5 \mathrm{GPa}$ \\
\hline Poisson tényező & 0,34 \\
\hline
\end{tabular}

\section{A próbatestek létrehozása}

A modellek a PTC Creo Parametric programmal lettek létrehozva. A program segítségével lehetséges különböző alapgeometriák egységcellákból való felépítése a „Lattice” funkció segítségével. (lásd: 2. ábra) A Lattice egy parametrizálható funkció, lehetséges többek között változtatni a dimenziók számát (23D), a kitöltés módját, az egységcellák típusát és méreteit, az egységcellákon belül a gerendák elhelyezkedését és vastagságát, és a gerendák keresztmetszetének alakját is (Szabó, 2018).

\section{Vizsgálati eljárás}

Az egyes próbatestek statikus igénybevételre vonatkozó mechanikai tulajdonságai meghatározhatók például egy nyomóvizsgálat segít ségével, melynek során az egyes próbatesteket két sík közé helyezzük, majd a síkokat egymáshoz közelítjük (3.ábra).

2. ábra: az alkalmą̧ató egységcellák (forrás: a Szerző)
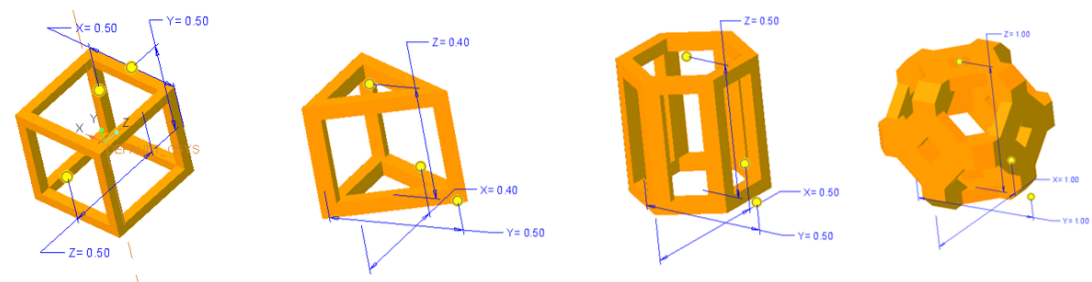
3. ábra: a nyomóvizsgálat vázlata (forrás: Szakács és tsai, 2012)

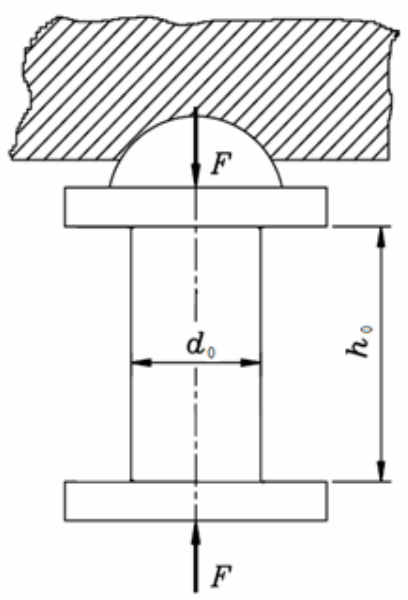

A vizsgálat során szenzorokkal mérhető az összenyomódás, és a kifejtett erő értéke, melynek alapján felrajzolható a próbatest erôelmozdulás görbéje, illetve feszültség-nyúlás görbéje, ezekből pedig meghatározható a próbatest több mechanikai tulajdonsága, mint például a folyáshatár, a nyomószilárdság, a merevség, és a rugalmassági modulusz.

A vizsgálat szimuláció segítségével is elvégezhetô a rugalmas alakváltozási tartományban, ahol ezek a görbék lineárisak. Egy FEMAP program segítségével végzett szimuláció során legelőször egy egységnyi, 0,001 mm-es elmozdulás kerül előírásra kalibráció végett, ami alapján kiolvasható, hogy ez esetben a geometriában mekkora a legnagyobb ébredő feszültség, majd a linearitás miatt meghatározható az, hogy hány milliméter elmozdulást kell előírni ahhoz, hogy a geomet- riában a megengedhetô maximális feszültség ébredjen. A kapott értékkel lefuttatható egy újbóli szimuláció, melynek végeredményeképp kiolvasható, hogy kritikus terhelésnél mekkora erő terheli a próbatest felső lapját. Az így kiolvasott erő, és az előírt elmozdulás értékek alapján felrajzolható a próbatest erőelmozdulás görbéje (Mankovits, 2018; Szabó, 2019).

\section{Szerkezetoptimalizálás mesterséges intelligencia segítségével}

Mivel a próbatestek (lásd: 1. ábra) parametrikusan változtatható egységcellákból (lásd: 2 . ábra) épülnek fel, ezért lehetséges az egyes paraméterek egy-egy inkrementummal való megváltoztatása, és minden egyes változtatás hatásának megvizsgálása a teljes próbatest mechanikai tulajdonságaira. Az összes paraméter egyenként, lépcsőzetesen történő változtatásával rendkívül nagy darabszámú modellt hozhatunk létre és vizsgálhatunk meg, ez az adatmennyiség pedig alkalmas lehet egy mesterséges intelligencia betanítására. A mesterséges intelligencia a makro méretben azonos, szabványos próbatesteken lefolytatott betanulás után alkalmas lehet más, komplex geometriák esetében is meghatározni, hogy adott mechanikai elvárás, illetve adott feltételek (például meghatározott felületi pórusméret) együttes teljesítésére milyen szerkezeti kialakítás lehet a legoptimálisabb.

A tanulási folyamat elvégezhetô szimuláció, vagy valódi vizsgálat segítségével is, de a magas darabszám miatt az anyag és gépköltségek megspórolása végett érdemesebb lehet szimulációkat végezni. Megfelelő informatikai hát- 
térmunka segítségével az inkrementálisan változtatott próbatestek automatizáltan létrehozhatók, és végeselemes szimulációs szoftverbe betáplálhatók, analizálhatók lehetnek, melyekból az MI önállóan kinyerheti a betanuláshoz szükséges adatokat, létrehozhat egy adatbázist, és később ezen adatbázis alapján hozhat döntéseket komplex geometriák adott terheléshez igazított, optimális mikro szerkezeti kialakításának meghatározásában.

A folyamat akár alkalmas lehet a mikro szerkezeti kialakítás, és a teljes próbatestek makro méretbéli mechanikai tulajdonságai közötti pontos matematikai összefüggések feltérképezésére is.

Az élettartam a statikus mechanikai tulajdonságok mellett nagyban függ a protézisek esetén ismétlődően fellépő terhelések miatt a szerkezet kifáradásnak való ellenállásától is. Ennek meghatározása általában valódi fárasztóvizsgálattal történik, mely alatt jelen esetben a komplett, szerkezetileg optimalizált, kinyomtatott csípőprotézis fárasztóvizsgálatát kell érteni. A mesterséges intelligencia ebbe a folyamatba is bevonható lehet a betanult adatbázis alapján, hiszen egy olyan feladatról van szó, mely során adott feltételek teljesítése mellett kell maximalizálni a kifáradási határt (Net10).

\section{Konklúziók}

Megnövelt élettartamú csípőprotézisek kifejlesztésén a világ több tájáról dolgoznak kutatók, ugyanakkor a feladat a mai napig nagy kihívást jelent a tudomány számára, mert ez a terület nagy hardver, szoftver, és inter- diszciplináris tudásbázis igénnyel rendelkezik. Az már bizonyított, hogy a csont bele tud nőni egy lyukacsos fogadófelületbe, és az is bizonyított, hogy milyen lyukacs/pórusméret esetén optimális ez a folyamat, ugyanakkor porózus szerkezetû implantátumok orvosbiológiai elvárásoknak megfelelően történő legyártása, és az ilyen implantátumok élettartama körül még sok kérdés nem került megválaszolásra. Jelen munka felvázol egy irányt, ami mentén mesterséges intelligencia bevonásával a mechanikai tulajdonságokkal szoros összefüggésben álló élettartamot, és annak növelését célzó kérdésekrôl pontosabb képet kaphatunk.

\section{Köszönetnyilvánítás}

A dolgozat elkészítését az EFOP-3.6.1-162016-00022 számú projekt támogatta. A projekt az Európai Unió támogatásával, az Európai Szociális Alap társfinanszírozásával valósult meg.

\section{Irodalom}

Balla VK, DeVasConCellos PD, Xue W, Bose S, Bandyopadhyay A (2009). Fabrication of compositionally and structurally graded $\mathrm{Ti}-\mathrm{TiO} 2$ structures using laser engineered net shaping (LENS). Acta Biomater. 2009 Jun;5(5): p. 1831-7.

DOI 10.1016/j.actbio.2009.01.011

Buchbinder, D., Schleifenbaum, H., Heidrich, S., Meiners, W. \& Bultmann J. (2012). High power selective laser melting 
(HP SLM) of aluminium parts. Physics procedia of the sixth international WLT conference on lasers in manufacturing, vol. 12A, Munich ICM, Germany; 2012. p. 271-8. DOI 10.1016/j.phpro.2014.08.177 Cooper DE, Stanford M, Kibble KA, Gibbons GJ. (2012). Additive manufacturing for product improvement at Red Bull Technology. Mater Des 2012;41: p. 226-30. DOI 10.1016/j.matdes.2012.05.017 E.O. Olakanmi,E.O., Cochrane, R.F. \& Dalgarno, K.W. (2015). A review on selective laser sintering/melting (SLS/SLM) of aluminium alloy powders: Processing, microstructure, and properties. Progress in Materials Science 74 (2015) p. 401-477. DOI 10.1016/j.pmatsci.2015.03.002

Gardan, J. (2016). Additive manufacturing technologies: State of the art and trends. International Journal of Production Research, 2016 Vol. 54, No. 10, 3118-3132. DOI 10.1080/00207543.2015.1115909

Gregolin RF, Barbosa FM, da-Rocha TL, deCamargo Zavaglia CA, Tokimatsu RC. (2013). Development and mechanical characterization of a mandibular prosthesis in titanium alloy fabricated by direct metal laser sintering (DMLS) Proceedings of 22nd international congress of mechanical engineering. 2013.

Hayashi T, Maekawa K, Tamura M, Hanyu K. (2005). Selective laser sintering method using titanium powder sheet toward fabrication of porous bone substitutes.
JSME Int J 2005;A 48(4): p. 369- $75 .$. DOI 10.1299/jsmea.48.369

Heinl P, Muller L, Korner C, Singer RF, Muller FA (2008). Cellular Ti-6Al-4V structures with interconnected macro porosity for bone implants fabricated by selective electron beam melting. Acta Biomater 2008; 4: p. 1536-44. DOI: $10.1016 /$ j.actbio.2008.03.013

Hughes, B. \& Wilson, G. (2015). 3D/Additive Printing Manufacturing: A brief history and purchasing guide. Reston Köt. 75, Kiad. 4, (Dec 2015/Jan 2016): 18-21

Huiskes R. (1993). Stress shielding and bone resorption in THA: clinical versus computer-simulation studies. Acta Orthop Belg. 1993;59 Suppl 1:118-29. PMID: 8116386.

Eldesouky, I., Abdelaal, O. \& El-Hofy, H. (2015). Femoral Hip Stem with Additively Manufactured Cellular Structures. 2014 IEEE Conference on Biomedical Engineering and Sciences (IECBES), 2014, pp. 181-186, DOI 10.1109/IECBES.2014.7047482

Johander, P., Eberhard, W., Necula, D., Haasl, S., \& Jung, E. (2007). Threedimensional electronics packaging and interconnection. 3D PACK. 4M Cross Divisional Report. Cardiff University, Cardiff. pp. 8-22. DOI 10.1007/s00170012-4605-2

Krawczak, P. (2015). Additive Manufacturing of plastic and polymer composite parts promises and challenges of 3D printing. eXPRESS Polymer Letters Vol.9, No.11 
(2015) 959. DOI

10.3144/expresspolymlett.2015.86

Lian Chen, Yong He, Yingxin Yang, Shiwei

Niu, Haitao Ren (2017). The research status and development trend of additive manufacturing technology. Int $J A d v$ Manuf Technol (2017) 89:3651-3660. DOI 10.1007/s00170-016-9335-4

Liu Y, Li S, Hou W, Wang S, Hao Y, Yang R, és társai (2016). Electron beam melted beta-type $\mathrm{Ti}-24 \mathrm{Nb}-4 \mathrm{Zr}-8 \mathrm{Sn}$ porous structures with high strength-to-modulus ratio. J Mater Sci Technol 2016;32: p. 505-8. DOI 10.1016/j.jmst.2016.03.020

Mankovits, T. (2018). Numerical analysis of unit cell models for orthopedic applications. IOP Conf. Series: Materials Science and Engineering 393 (2018) 012019. DOI 10.1088/1757-899X/393/1/012019

Naoya Taniguchi, Shunsuke Fujibayashi, Mitsuru Takemoto, Kiyoyuki Sasaki, Bungo Otsuki, Takashi Nakamura, Tomiharu Matsushita, Tadashi Kokubo, Shuichi Matsuda (2015). Effect of pore size on bone ingrowth into porous titanium implants fabricated by additive manufacturing: An in vivo experiment. Materials Science and Engineering C 59 (2016) 690-701. DOI 10.1016/j.msec.2015.10.069

Net1: A csípő felnőttkori betegségei.

Letöltés: 2021.03.08. Web: http://www.drkovacsgy.hu/cpg/338225/ A-csipo-felnottkori-betegsegei

Net2: Csípőprotézis. Letöltés: 2021.03.08. Web: http://www.drkovacsgy.hu/cpg/731599/ Csipoprotezis

Net3: A csípőprotézis típusai. Letöltés: 2021.03.08. Web: http://www.drkovacsgy.hu/cpg/955851/ A-csipoprotezis-tipusai

Net4: Rapid manufacturing: overview. Letöltés: 2021.03.17. Web: http://www.csa1.co.uk/discoveryguides/ rapidman/overview.php

Net5: Selective Laser Melting Machine SLM®280 2.0. Letöltés: 2018.11.13. Web: https://www.slmsolutions.com/products/machines/selecti ve-laser-melting-machine-slmr280-20

Net6: EOS M 290 The Additive

Manufacturing System for the Production of Serial Components, Spare Parts and Functional Prototypes Directly in Metal. Letöltés: 2021.03.19. Web: https://www.yield247.com/viewer/1097 /download.pdf

Net7: Laser engineered net shaping. Letöltés: 2021.03.19. Web:

https://en.wikipedia.org/wiki/Laser_engi neered_net_shaping

Net8: Direct Metal Deposition (DMD)

Fabrication Process for Metal 3D Prints. Letöltés: 2021.03.19. Web: https://www.sculpteo.com/en/glossary/ dmd-definition/

Net9: ISO 13314:2011. Mechanical testing of metals - Ductility testing Compression test for porous and cellular metals. Letöltés: 2021.03.19. Web: https://www.iso.org/standard/53669.ht $\mathrm{ml}$ 
Net10: High-level expert group on artificial intelligence. A definition of AI: Main capabilities and disciplines. Letöltés: 2021.05.10. Web:

https://www.aepd.es/sites/default/files/ 2019-12/ai-definition.pdf

Stoodley MA, Abbott JR, Simpson A. (1996). Titanium cranioplasty using 3-D computer modelling of skull defects. $J$ Clin Neurosci 1996;3(2): p. 149-55. DOI: 10.1016/s0967-5868(96)90009-0

Sunpreet Singh, Seeram Ramakrishna, Rupinder Singh (2017). Material issues in additive manufacturing - A review. Journal of Manufacturing Processes 25 (2017) p. 185200. DOI 10.1016/j.jmapro.2016.11.006

Szabó Dániel (2018). A fémnyomtatás lehetőségei az implantátumtervezésben. Gépészmérnöki Kari TDK 2017/18/2/129 http:/ / hdl.handle.net/2437/261625

Szabó Dániel (2019). Egységcellákból felépített próbatest mechanikai vizsgálata. Gépészmérnöki Kari TDK 2019/2020/1/ 141 http://hdl.handle.net/2437/277904 Thomas Duda, T. \& Venkat Raghavan, L. (2016). 3D Metal Printing Technology. IFAC-PapersOnLine 49-29 (2016) 103110. DOI 10.1016/j.ifacol.2016.11.111

Tiwari Sunil Kumar, Pande Sarang, Agrawal Sanat, Bobade Santosh M. (2015). Selection of selective laser sintering materials for different applications. Rapid
Prototyping Journal; Bradford Köt. 21, Kiad. 6, (2015): 630-648. DOI 10.1108/RPJ-032013-0027

van Zyl, I., Yadroitsava, I. \& Yadroitsev, I. (2016). Residual stress in Ti6Al4V objects produced by Direct Metal Laser Sintering. South African Journal of Industrial Engineering December 2016 Vol 27(4), pp 134-141. DOI 10.7166/27-4-1468

Wang Zhonghan, Wang Chenyu, Li Chen, Qin Yanguo (2017). Analysis of factors influencing bone ingrowth into threedimensional printed porous metal scaffolds: A review. Journal of Alloys and Compounds 717 (2017) 271-285 DOI 10.1016/j.jallcom.2017.05.079

XiaoHui S, Wei L, PingHui S, QingYong S, QingSong W, YuSheng S, és tsai. (2015).

Selective laser sintering of aliphatic polycarbonate/hydroxyapatite composite scaffolds for medical applications. Int $J$ Adv Manuf Technol 2015;81: p. 15-25. DOI 10.18063/IJB.v5i1.148

Xie F, He X, Cao S, Qu X. (2013). Structural and mechanical characteristics of porous 316L stainless steel fabricated by indirect selective laser sintering. J MaterProcess Technol 2013;213: p. 838- 43. DOI 10.1016/j.jmatprotec.2012.12.014 


\title{
MODERN TECHNOLOGIES AND FOREIGN LANGUAGE TEACHING
}

\section{Szerző:}

Tomáš Godiš

Trnava University in Trnava (Slovakia)

\section{Lektorok:}

Orsolya Hegedûs

Constantine the Philosopher

University in Nitra (Slovakia)

Ildikó Pšenáková

Trnava University in Trnava

(Slovakia)

E-mail:

tomasgodis@gmail.com ...és további két anonim lektor

\begin{abstract}
Absztrakt
A modern kommunikációs technológiáknak köszönhetően a nyelvoktatás napjainkban forradalmat él át. Az új kreatív módszertani eljárások, a hallgató oktatási igényeihez való jobb eligazodás vagy a tanítás nagyobb autonómiája csak néhány előny a modern technológiákból. Ezenkívül a nyelvgyakorlatok és az átfogó nyelvi programok vagy alkalmazások különféle online portáljainak köszönhetően a tanárnak számos autentikus tananyag is rendelkezésre áll, amelyek lehetővé teszik számára, hogy hatékonyabban teljesítse az oktatási célokat, reflektáljon a tanulói igényeire, motiválja őket és oktatási potenciáljuk teljes kihasználására késztesse őket. Cikkünkben mélyebben az online nyelvi portálra és az átfogó nyelvi programokra fogunk koncentrálni.
\end{abstract}

Kulcsszavak: E-learning, nyelvi programok, online nyelvportál-portálok, modern technológiák

Diszciplina: pedagógia

\begin{abstract}
Thanks to modern communication technologies, language teaching is experiencing a revolution today. New creative methodological procedures, better orientation to the student's educational needs or greater autonomy of teaching are just some of the benefits that modern technologies bring. Moreover, thanks to various online portals of language exercises and comprehensive language programs or applications, the teacher also has several authentic teaching materials at his disposal, which enables him to more effectively
\end{abstract}


fulfill educational goals, reflect the needs of his students, motivate them and make full use of their educational potential. In our paper, we will focus more deeply on the online language portal and comprehensive language programs.

Keywords: E-learning, language programs, online portals of language exercises, modern technologies

Discipline: pedagogy

Godiš, Tomáš (2021): Modern technologies and foreign language teaching. Mesterséges intelligencia - interdiszciplináris folyóirat, III. évf. 2021/1. szám. 87-100. doi: 10.35406/MI.2021.1.87

The global pandemic and the resulting school closure measure have radically affected (not only) foreign language teaching. This period will go down in school history as the so-called "Homeschooling" - i.e. home elearning of students through information and communication technologies, especially computer programs or applications (e.g. MS Teams, Webex or Skype). Even before the pandemic, integrating communication technologies into teaching was underway, but the pandemic significantly accelerated it. At the same time, both the advantages and disadvantages of these technologies have been revealed. In the teaching process today, we encounter various types of information and communication technologies - they are mainly interactive whiteboards, radio and television equipment, computers and many programs not only for teaching a foreign language. Undoubtedly, the most significant advantages of these electronic means include streamlining the teaching process, clearer communication (using graphs, visualizations, simulations), new teaching methods and procedures, an endless source of information, more autonomous teaching elements, a better reflection of students' educational needs or unrestricted access to authentic language materials (video, audio or reading texts). On the other hand, the integration of modern technologies into education - as already mentioned - also reveals many problems, especially in the form of outdated technical equipment in schools, slow connection to the Internet, which cannot cope with the onslaught of connecting hundreds of computers at once, which reduces the quality of the teaching process.

It should be noted that many students, mainly from the socially weaker sections of society, do not have a computer at all, so they cannot be educated electronically. Therefore, thanks to the 'Renew Europe' program, the European Union has decided to solve this 
problem and invest many millions of euros in digitization - especially in modern technical equipment for schools. The goal is the availability of e-learning for all students. However, the sudden transition to distance teaching also showed shortcomings in the media-didactic competence of teachers. During the transition to distance learning, many teachers had a problem implementing teaching in electronic form and first had to complete various webinars or trainings. For this reason, too, one of the priority goals of universities or educational institutions preparing future teachers must be to educate them in media skills and thus improve their didactic competencies.

\section{Foreign language and modern technologies}

As a grouping of 26 member states (including Slovakia), the European Union is defined as a multicultural environment in which it is necessary to speak more foreign languages. In the territory of the Member States, 440 million people speak 24 official and more than 150 unofficial languages. The English language is undoubtedly considered to be the lingua franca. However, mainly social and economic reasons increasingly require the command of other languages chiefly the economically strongest and culturally most influential countries, and thus German, Spanish, French or Italian. The EU enshrined support for teaching at least two foreign languages in the Lisbon and Barcelona Declarations of the EU Summits in Lisbon (2000) and Barcelona (2002). Based on these declarations, every EU citizen should have access to the teaching of at least two foreign languages (EU Fact Sheets. 2021. online). The EU also supports the teaching of foreign languages financially - through various $\mathrm{Eu}-$ ropean projects of the European Social Fund, but also by building renowned research institutions such as the "European Research Centre for Multilingualism and Language Learning" - (MERCATOR) or the "European Centre for Foreign Languages" (ECML). Both institutions are dedicated, among other things, to the methodology of teaching foreign languages and are behind a unique system for assessing language skills - the "European Framework of Reference for Languages" (CEFR).

Thanks to EU support, many Slovak schools have succeeded in equipping themselves with modern technologies and introducing a certain standard of e-learning. However, modern technologies in the teaching of (not only) foreign languages are not a new phenomenon. Technical means such as interactive whiteboards, radios, data projectors and DVD technology have been used for a long time. These "didactic media" ("diaktische Medien") as they are called by German didactics e.g. J. Roche (2008. p. 246) - they are "bearers and mediators of information in the context of teaching and learning" (Erdmenger 1997. online). Didactic media are thus technical means that enable the teacher to convey new knowledge to students more clearly and effectively and support them in acquiring new information and skills. Therefore, it is possible to say that they are a 
means of support for both the teacher and the student. Moreover, as Kilian points out, "didactic media also positively influence students' concentration or attention, arouse their interest in language as a means of communication and are associated with a higher motivation to learn it" (Kilian 2008. p.21.).

New modern electronic means are increasingly being used to teach foreign languages, namely various online portals of language exercises or complex language programs. These are available thanks to computers, tablets or smartphones. All these portals and programs make it possible to transform traditional teaching into modern teaching gradually. However, the way is not the complete electronization of education but the impenetration of traditional and electronic forms of education. This form is also referred to as "Blended Learning" or "CALL Computer Assisted Language Learning" (Pokrivčáková, 2008. p. 162). However, Didactics Arnold, Kilian, or Roche agree that teaching through didactic media without a concept, meaningful didactic methods, or transparently formulated educational goals does not automatically mean more effective or motivating education for the student. That is also why there is no need to condemn all methods of traditional teaching and, on the other hand, to overestimate the methods of elearning. (Kilian, 2018. p.23). Combining traditional teaching with media (electronic) elements is ideal because it combines the most effective traditional and electronic teaching methods (Bender, 2017. p. 66).
As there is still no relevant didactic handbook dealing with integrating technical means into language teaching, the teacher must rely only on his media competencies and didactic skills in creating such teaching. However, they must take into account the following advantages and disadvantages of both forms of teaching:

\section{Traditional teaching:}

- is limited by place and time - teaching takes place in the premises of the educational institution and in a specific teaching time,

- the teacher cannot (logically) fully satisfy the educational needs of all students, which limits the effectiveness of the teaching process,

- does not allow to make full use of the total educational potential of students - groups can be (in terms of the level of knowledge) heterogeneous - some students are therefore overloaded, while other students are bored with teaching,

- the content of the information provided may also be limited due to the pace of teaching,

- there is little room for autonomous teaching,

- also allows the use of forms of group work or joint project,

- the teacher can intervene at any time during the lesson, and we do not know whether to explain the problematic subject again,

- allows better use of group work as well as cooperative project teaching, 
- the teacher is better able to diagnose students' educational problems and suggest possible solutions,

- is associated with a high level of social integration within the classroom (or educational group).

\section{Teaching through didactic media:}

- teaching moves to virtual space and allows more flexible use of teaching time (e.g. pre-recorded lessons can be watched at virtually any time),

- brings a higher degree of autonomy to education - based on their educational needs, students can manage themselves, e.g. pace of teaching, listen to the recording several times, return to obscure exercises, re-study the teacher's interpretation - students become coresponsible for their language progress,

- thanks to interactive online exercises, students can choose for themselves what type of exercises they want to develop, sometimes they can also choose their content and thus to pay more attention to what they do not understand and to pay less attention to what they already have sufficient control over,

- online exercises are associated with immediate feedback (e.g. in the form of evaluation of elaborated exercises and the level of quality of competencies),

- the teacher can better reflect on the educational needs of individual students students are given the opportunity to make full use of their educational potential,
- allows the teacher to include more creative elements in the teaching (e.g. more electronic exercises or new methodological procedures - didactic methods),

- places high demands on the pedagogical competence of the teacher,

- changes the role of the teacher, who becomes the manager and planner of the lesson,

- allows presenting information and facts in a more transparent way (through graphs, tables or interactive infographics),

- the student is isolated at the screen and does not build complete social contacts and relationships,

- some forms of education are more difficult to use - e.g. group work, joint project.

Despite certain disadvantages, modern technologies in language education are a huge benefit and are simply inseparable from the modern teaching process. In the following chapters of our paper, we will focus on new forms of modern technology in language teaching, namely online portals of language exercises, language training programs and mobile applications.

\section{Online portals of language exercises in foreign language teaching}

In today's language education, in addition to traditional electronic media (radio, television technology, interactive whiteboard or data projector), various online portals of language exercises, language computer programs and mobile applications are also beginning to be used. 
Online language training portals are available via a computer or tablet with an Internet connection. It is a set of isolated interactive exercises whose goal is to fix different language structures. According to Roche, these are tutorials (Roche 2008, p. 246), allowing students to repeat phonetic, grammatical or lexical structures while representing a specific electronic alternative to exercises in a printed textbook or paper form. The most significant difference is in the interactive elements that online exercises offer, allowing users to deal with them according to their own educational needs (for example, choose their type, form, content).

The creators of these portals are experienced didactics and primarily represent a supplement to specific foreign language textbooks. Due to the connection to specific language textbooks (or literature), most such portals are located on publishers' websites. For example, the Hueber publishing house offers the so-called "Lehrwerkservice" (en: textbook service) - the online exercise portal (www.hueber.de). Important portals for teaching German also include those from Klett Publishing (www.vydavatelstvoklett.sk), Langenscheidt (www.langenscheidt.de) or the Goethe Institut (www.goethe.de). As an example, below is a visual of the German exercise online portals from Hueber and Klett (Figure 1).

Online exercise portals are interactive programs that bring a high degree of autonomy to teaching - the student can decide for themselves how much time they need to de-
Figure 1: Hueber and Klett online portal. Source: Net1, Net2

Hueber Portal - Textbook Delfin

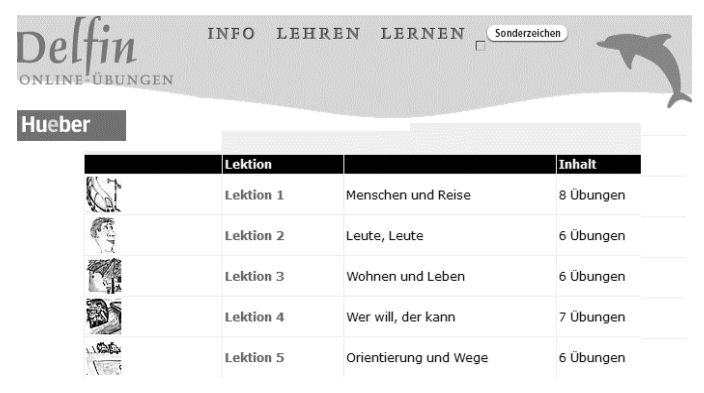

Klett Portal - German language
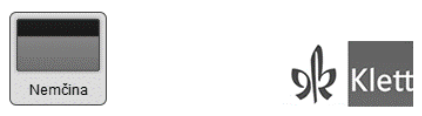

VÝBER UČEBNICE:
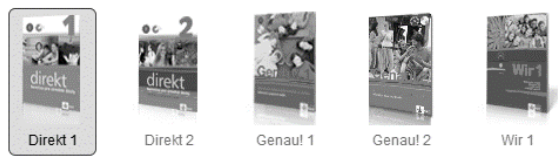

ONLINE CVIĆENIA

VÝBER KAPITOLY

1. Erste Kontakte

ZAHRNÚT̃ TIETO TYPY OTÁZOK:
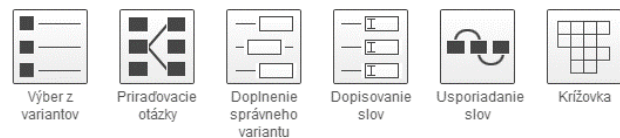

velop an exercise, which exercise they want to return to again and rework, or which exercise they want to skip (because they already understand the curriculum sufficiently). Some portals - such as the Klett portal - even allow the student to choose the topic of the exercises and their form (e.g. assignment, supplementation, crossword, sentence translation exercises - see Fig.1). In this way, the 
student can significantly influence their learning process based on their real educational needs - they thus become co-creators.

The mentioned functions undoubtedly result in numerous advantages of online portals, both for students and teachers. The student will gain more effective teaching and faster language progress with increased motivation to learn the language. The teacher can achieve the educational goals faster and at the same time make full use of the educational potential of the student according to their needs. Students with higher educational performance can enter, e.g. more exercises, and students with less educational performance can, on the contrary, enter less - this does not make students unnecessarily overloaded, and they do not get bored either. At the same time, the teacher will get more time to devote more to those students who do not understand the curriculum sufficiently. They also can take a creative approach to the teaching, integrating new didactic procedures or methods.

After completing the individual exercises on the online portals, the student will receive feedback in evaluating the correctness of the answers and recommending further progress in learning. In our opinion, this type of assessment is very effective because the student immediately knows whether his language skills are sufficient or it is necessary to repeat the curriculum and learn it again. The student can return to the elaborated exercises and do them again. Although online portals usually contain exercises for fixing or repeating lexical, grammatical or phonetic structures of a language (e.g. vocabulary, grammatical phenomena, pronunciation, accent), they often include fun language games or tongue twisters. A significant advantage of some portals is that they are directly linked to educational sites by hyperlinks, where it is possible to find more difficult subjects and have them explained again. One of these websites is the Slovak website www.oskole.sk or the popular German websites www.deutsch.lingolia.com as well as www.mein-deutsch.de.

As already mentioned above, online portals are tutorial (controlled) programs - they do not offer logically consecutive teaching materials but individual monothematic isolated groups of exercises. For this reason, too, teachers must plan them in the teaching process based on given didactic and educational goals. Blended learning is, therefore, a kind of teaching where the teacher becomes a manager, who is required to have a high level of media and didactic competencies, but is also a student's assistant because he/she must teach them not only to work correctly with the portal but also to read feedback results.

Today, there are many portals with online exercises that offer a considerable amount of content. However, many teachers (and sometimes their students) are users and creators of these exercises. Many teachers create materials tailored to their students, whom they know well and know their educational needs. Programs such as Hotpotatoes, Wordwall, Lingofox or, e.g. simulator of creating electronic exercises of the Goethe Institute such as Übungsblätter Selbst gemacht or Suchselmaschine help them to create new 
electronic as well as paper materials (cf. Pšenáková and Hegedűs, 2010) on learning English through mobile devices as well as Pšenáková and Hegedûs (2017) on interactivity in educational materials for language training (Figure 2). In the following lines, we want to introduce the Schuselmaschine and Wordwall programs in more detail, which are also used in didactics courses at the University of Trnava as part of the training of future teachers.

Figure 2: : Programs for creating Hot Potatoes, Wordwall, Suchsel exercises. Sources: Net5, Net7

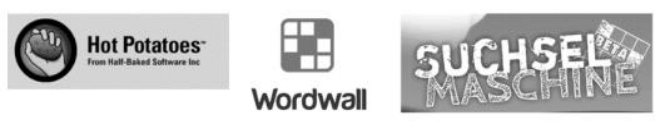

The Suchselmaschine exercise generator is primarily intended for practising vocabulary or word phrases of various language levels. Therefore, it is a simple program that quickly creates crossword puzzles in electronic or printed form. The teacher can create a crossword puzzle in up to four levels of difficulty (easy, medium, hard, and very hard) and insert an unlimited number of terms into it. Thus, it will create exciting crossword puzzles from various thematic areas. However, this generator is used not only by teachers but also by their students, who create crossword puzzles for their classmates and thus practise their language and their media competencies (often in the form of a crosssectional curriculum in computer science or foreign language lessons). The Figure 3 presents the process of creating crossword puzzles in the Suchselmaschine generator. Based on the entered data, the generator creates a crossword (in this case, an eightway).

A similar program for creating exercises is Wordwall, which, unlike Suchselmaschine, however, allows to create at least 45 types of different exercises (e.g., word quiz, memory game, word wheel, find the missing verb, crossword puzzle, anagram, assignment exercises, correct word order exercise, card game and many other types of tasks). The teacher can thus choose the type of exercise that is interesting and motivating for the students (see Fig. 4).

Figure 3: Crossword generator "Suchselmaschine" and a created exercise. Source: Net7
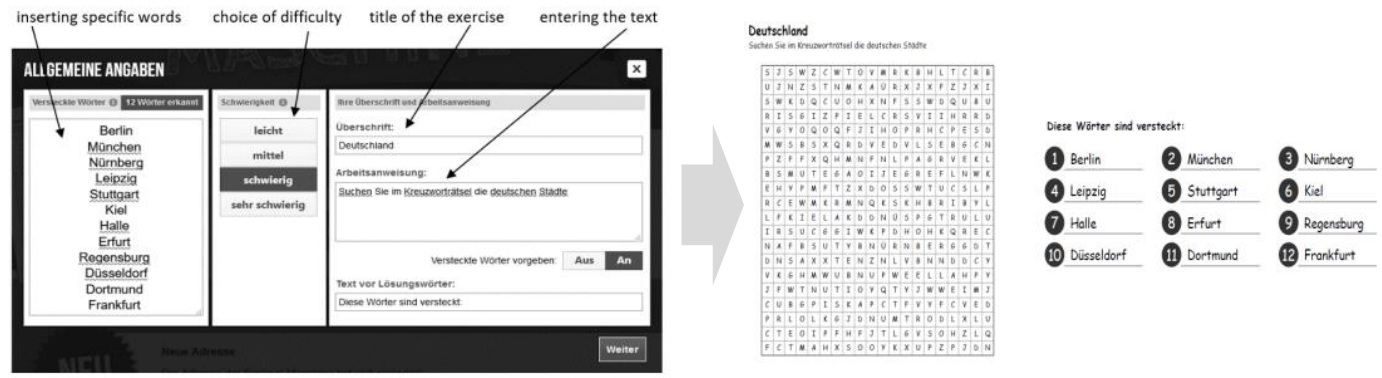
Figure 4: Selection of various exercises in the program Wordwall. Source: Net5

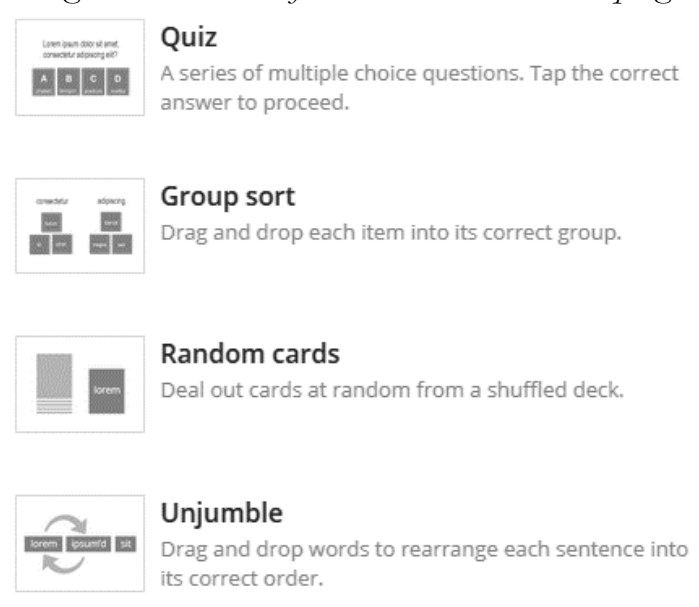

Match up

Drag and drop each keyword next to its definition.

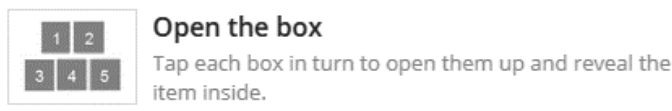

ब. Matching pairs

으 Tap a pair of tiles at a time to reveal if they are a match.

\section{Anagram}

mand vanun Drag the letters into their correct positions to unscramble the word or phrase.
Therefore, it can be stated that this program has a much wider use than the previous one, and it is possible to create exercises not only to repeat the vocabulary but also the grammatical, orthographic or syntactic structure of the language.

If we want to create, e.g. "match up" exercise, it is possible to enter an unlimited number of terms and definitions, which the student has to combine. The teacher can enter both the text of the assignment and the name of the exercise. The process of creating an exercise in the Wordwall program is presented in Fig. 5.

All exercises created in Wordwall are fully electronic, and students can download them via a shared link. All are both interactive and come with feedback. The student will learn immediately after their elaboration whether their solution is correct or incorrect.
Figure 5: Wordwall - generator of "Match up" exercise. Source: Net5 $0: 13$

\begin{tabular}{|c|c|c|c|}
\hline $\begin{array}{c}\text { der } \\
\text { Wasserkocher }\end{array}$ & der Fernseher & das Handy & der Computer \\
\hline $\begin{array}{c}\text { die } \\
\text { Waschmaschine }\end{array}$ & \multicolumn{3}{|c|}{ Damit kann man die Wäsche waschen. } \\
\hline & \multicolumn{3}{|c|}{ Damit kann man Wasser für den Kaffee kochen } \\
\hline & \multicolumn{3}{|c|}{ Damit kann man im Internet surfen. } \\
\hline & \multicolumn{3}{|c|}{ Damit kann man Nachrichten auf RTL ansehen } \\
\hline & Damit kan & man tele & nieren. \\
\hline & & Submit Answe & \\
\hline
\end{tabular}

Programs for creating tailor-made teaching materials are trendy because they help teachers increase students' motivation, reflect their educational needs and, last but not least, make the teaching process more effective. At present, however, complex language programs are also beginning to be established in teaching. We deal with this phenomenon in more detail in the next chapter. 


\section{Complex programs and applications for foreign language teaching}

Today, when teaching languages, we encounter various complex educational computer programs and mobile applications in Slovakia (Fig. 6.). The best known are mainly freeware programs Babbel, Duolingo, Lingvist, Rosetta Stone and others.

Figure 6: Computer and mobile language applications. Source: Net6, Net9, Net10

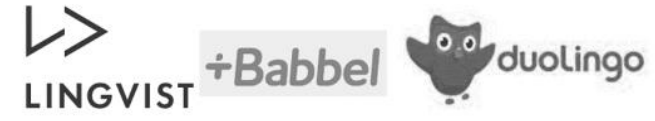

Unlike online language practice portals, these programs and applications are complex and thus contain consecutive teaching units or even entire language courses. Thus, they do not represent a grouping of content-isolated exercises but didactically connected units, which serve not only for the repetition or fixation of the learned curriculum but also for explaining the new curriculum and its practical demonstration. They are primarily intended for self-taught people who want to learn the language, for example, in their free time, but they are also very well used in full-time teaching with a lecturer or teacher. It is the teacher's contribution that multiplies the student's efficiency and success in using these programs and applications. The content of these programs and applications are exercises for the development of receptive and productive language skills - and thus reading, writing, listening and speaking. Thanks to the increasingly modern technology of computers or mobile phones, it is also possible to further develop the speaking skill, which was limited by the microphone quality in the programs and was not given sufficient attention.

The structure of complex programs and mobile applications is strictly logical, clear and easy to navigate. Some applications and programs are structured like a classic strategy computer game. The Duolingo application, for example, has such a structure (see Fig. 7). Its content is divided into several units (from the least to the most demanding), representing certain language levels. To get to a higher level, they must achieve a specific point score in the lower level; otherwise, the program will not move them to a higher level. The aim is to achieve the highest possible language level and thus achieve the best possible knowledge of the language. Just as in the game, its user collects coins for individual completed tasks, the user of this language program gets points that place him in the order of the most effective (or fastest) learning users. We evaluate this motivating element very positively, as it supports healthy competition among students. A crucial part of this program is also feedback in the form of evaluation of completed tasks. It can be defined as multilevel - it follows each item in the exercise, after each exercise, after each lesson and finally after each language level (see Fig. 7). Thus, the student knows precisely whether he/she masters the subject matter sufficiently or has to repeat it. Part of the feedback is also the so-called "Ladders of 
Figure 7: Program Duolingo - structure and evaluation. Source: Net6

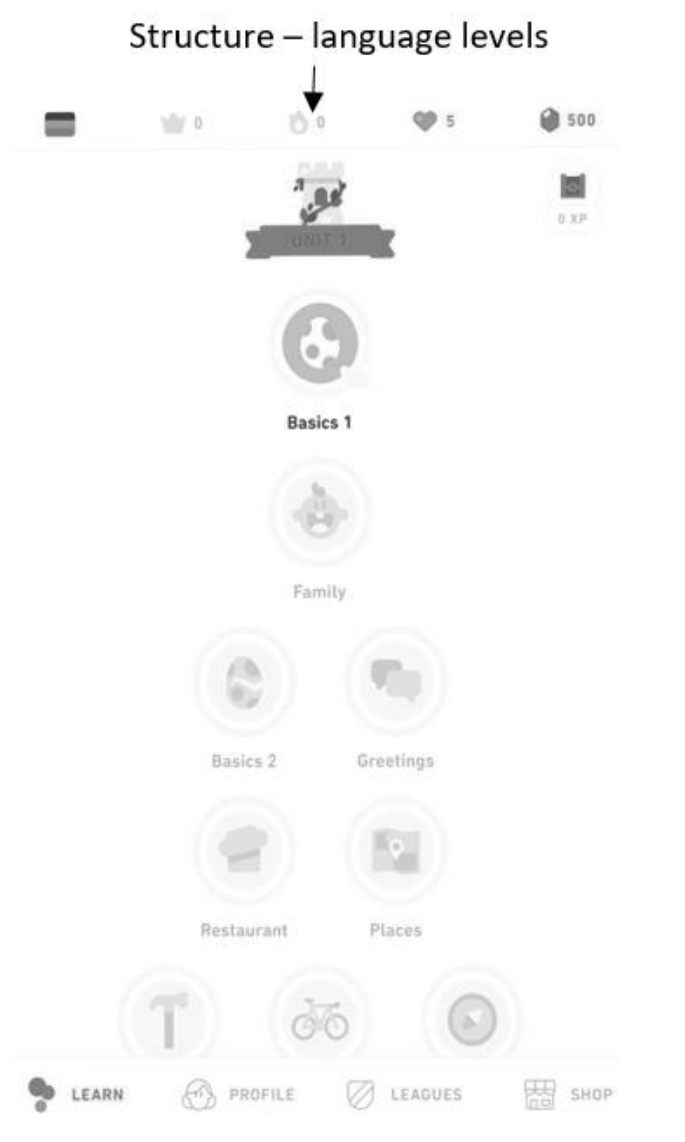

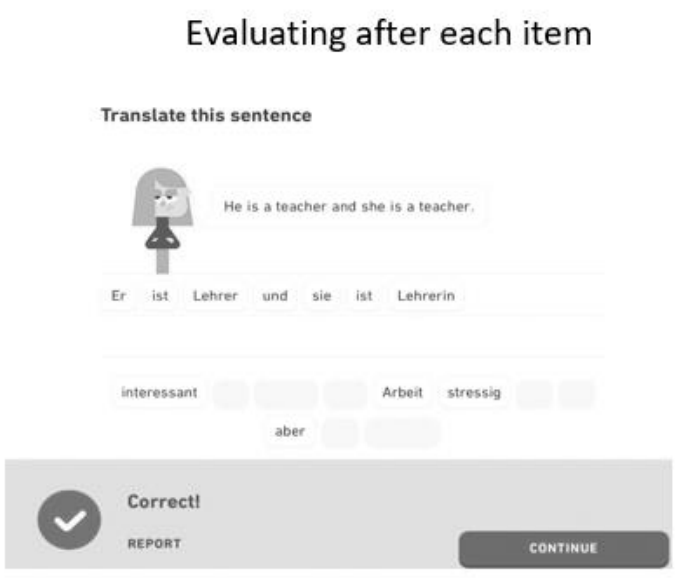

Evaluating after the lesson

Lesson

complete!

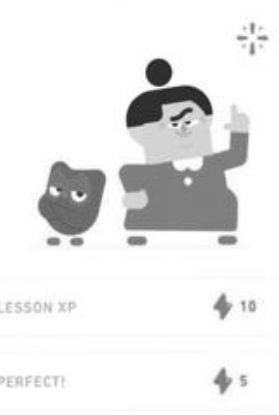

success". This "ladder" records which three students are the most active, achieve the best results, progress the fastest, have the most progressive exercises, the minor errors or the percentage of success in the teaching process within the defined class. Intentionally it is not given to lower-ranking students so that they do not feel demotivated.
The individual levels with tasks are coherent - they represent monothematic units (e.g. family, work, travel, shopping, media) and include relevant grammar. Duolingo also offers students so-called grammar cards - and therefore cards with an explanation of the practised curriculum. If the student does not complete the task correctly or gets few points, 
the program will allow them to re-study the written explanation of the grammatical phenomenon. The disadvantage is that several examples are missing, and there is a risk that, despite studying, the student may not understand the material correctly. For this reason, too, the effectiveness of teaching without interpretation and guidance by teachers is questionable. The teacher has essential functions, apart from a social one, also an explanatory one. If the student does not understand the material, the teacher can explain it in another way to make them understand it as best as possible. However, the teacher must know the student's learning style as well as his intellectual characteristics. Diagnosis of a student within the educational process is one of the essential skills of a teacher, and current language programs do not have this skill.

We consider the danger of insufficient or incorrect (inaccurate) understanding of various grammatical phenomena and lexical elements of the language to be the biggest problem of electronic educational programs. We gained this experience during practical training at language schools, where applicants often come after having completed a course for self-study. It is challenging for a teacher to wean away from students misunderstandings and to teach their curriculum correctly. Misunderstanding grammatical phenomena and their subsequent learning are very frustrating from the student's point of view. A typical example from the German language is modal verbs in the perfect (in the compound past tense). Modal verbs are always used as auxiliary verbs in the perfect infinitive form (e.g., Ich habe ins Kino gehen dürfen.). Unfortunately, very little space is devoted to this phenomenon in electronic programs, and students often learn simply that even a modal verb (as well as any full verb) must stand in the sentence in the form of a participle of the past (Partizip II.), which is a mistake (e.g., Ich habe ins Kino gehen gedurft.) This is just one example of a frequent error, but unfortunately, in reality, we encounter many others. Moreover, for this reason, we are convinced that the explanation of the material by the teacher is necessary for the process of teaching the language - the program (however good it may be) is not fully capable, in our opinion. Therefore, the teacher is an irreplaceable component of the teaching process, and their contribution can increase the effectiveness of the educational program.

\section{Conclusion}

The aim of online exercise portals and comprehensive educational programs or mobile applications is to achieve the highest possible effectiveness of language education. Despite some disadvantages, these electronic means of teaching foreign languages bring huge advantages. Let us mention, e.g. unlimited source of information, amount of authentic materials (texts, videos, listening), new methodological procedures, a better reflection of students' educational needs and educational potential, increased student motivation (compared to traditional teaching), 
higher autonomy of teaching, creative approach by the teacher, faster fulfilment of educational goals and, last but not least, more efficient and better teaching. The teacher has a central role in teaching with integrated modern communication technologies. It is he/she who must organize or plan the teaching well and respect the defined educational goals, the language level of the students, their educational needs, learning style or educational potential. Doing so requires excellent didactic or media competencies. Due to these increasing demands on the teaching profession, universities and educational institutions must prepare their students for future careers in both the didactic and media fields.

\section{References}

Arnold, P., Kilian, L., Thillosen, A., Zimmer, G. (2018). Handbuch E-Learning. Bertelsmann Verlag. Bielefeld Bender, I. (2017). Mediendidaktik Potenziale,Szenarien und Formate der digitalisierten Lehre. online. (Downloaded: 2.5.2021). Web: https://www.unirostock.de/storages/unirostock/UniHome/Weiterbildung/KOS MOS/Mediendidaktik.pdf

Erdmenger, M. (1997). Medien im Fremdsprachunterricht, Hardware, Software und Methodik. TU - Braunschweig.

Braunschweig. (Downloaded: 12.5.2021). Web: https://publikationsserver.tu- braunschweig.de/receive/dbbs_mods_00 001158

Európsky parlament (2021). Informačné listy jasyková politika EU. (Downloaded 12.5.2021). Web: https://www.europarl.europa.eu > FTU_3.6.6.pdf

Lehner, M. (2019). Didaktik. Haupt Verlag. Bern.

Net1. Downloaded: 20.06.2021. Web: www.hueber.de

Net2. Downloaded: 20.06.2021. Web: www.vydavatelstvoklett.sk

Net3. Downloaded: 20.06.2021. Web: www.goethe.de

Net4. Downloaded: 20.06.2021. Web: www.oskole.sk

Net5. Downloaded: 20.06.2021. Web: https://wordwall.net/

Net6. Downloaded: 20.06.2021. Web: www.duolingo.com

Net7. Downloaded: 20.06.2021. Web: www.suchsel.bastelmaschine.de

Net8. Downloaded: 20.06.2021. Web: https://hotpot.uvic.ca/

Net9. Downloaded: 20.06.2021. Web: www.babbel.com

Net10. Downloaded: 20.06.2021. Web: www.lingvist.com,

Pokrivčákova, (2008). S. et al. Inovácie a trendy vo vyučovani cudzích jazykov u riakov mladšieho školského veku. Univerzita Konštantína Filozofa, Nitra

Pšenáková, I. and Hegedűs, O. (2010). Let's learn English through Molibe Phones. Romanian Journal of Education, 1/1, 43-48. 
Pšenáková, I. and Hegedűs, O. (2017).

Interactivity in educational materials for

language training. Módszertani közlöny, 7/1, 219-228.
Röche, J. (2008). Fremdsprachenerwerb Fremdsprachendidaktik. Narr-Francke Attempto Verlag. Tübingen 
MÜHELY, RENDEZVÉNY 


\section{LEGYEN ÖN IS AZ ELSŐ SZÁZEZER KÖZÖTT, AKI TELJESÍTI AZ MI KIHÍVÁS MESTERSÉGES INTELLIGENCIA ALAPOZÓT!}

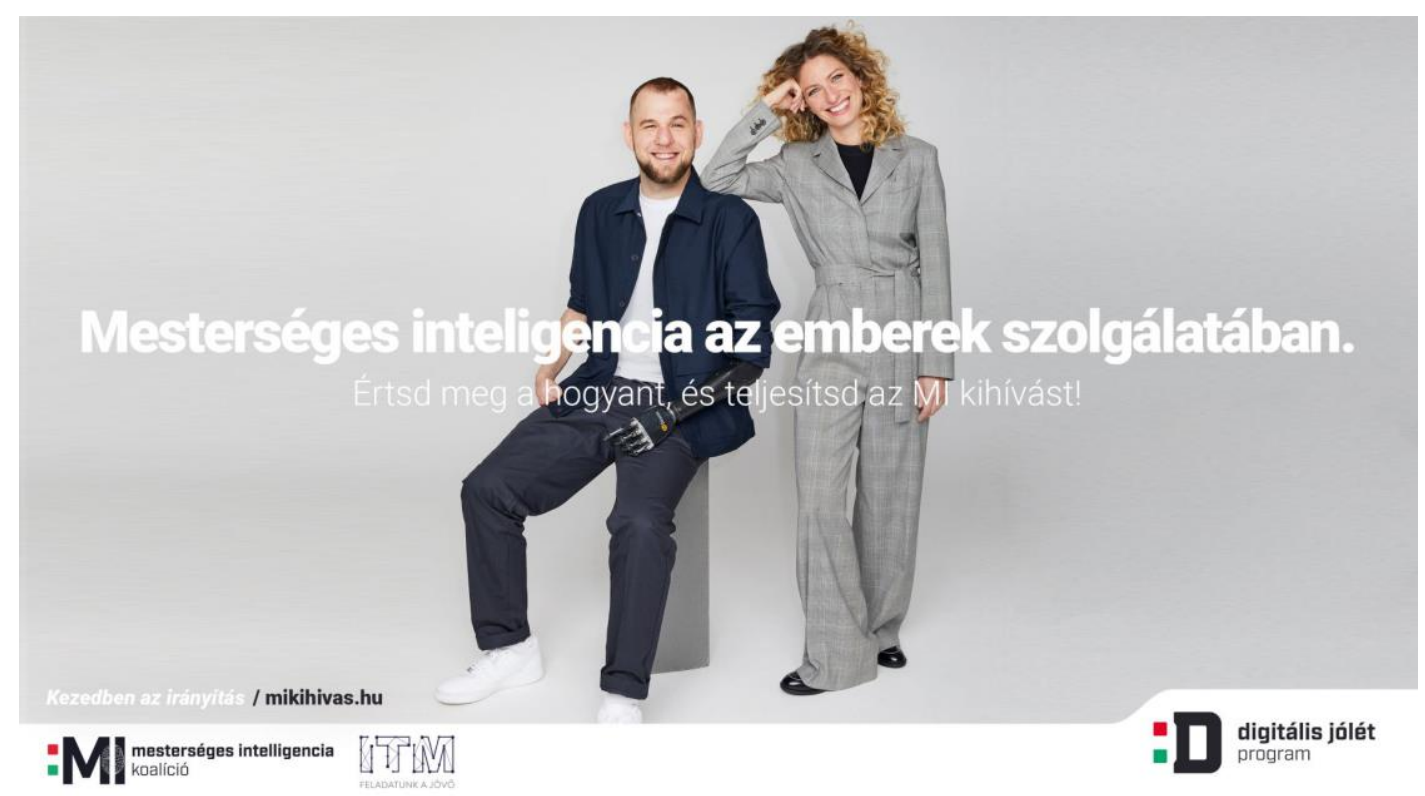

A mesterséges intelligencia alapjaival megismertető kurzus augusztus 31-ig történő teljesítésével akár PS5 konzolt vagy értékes videókártyát nyerhet. A kampányt június óta két olyan fiatal szakember is támogatja MI nagyköveti minőségben, akiknek mindennapi munkájában kiemelkedő szerepet játszik az MI. Gara Tícia nemzetközi sakknagymester és Lévay György kutatási menedzser az MI Koalíció csatornáján elérhető videósorozatban hívja fel a figyelmet a technológia megismerésének fon-tosságára.

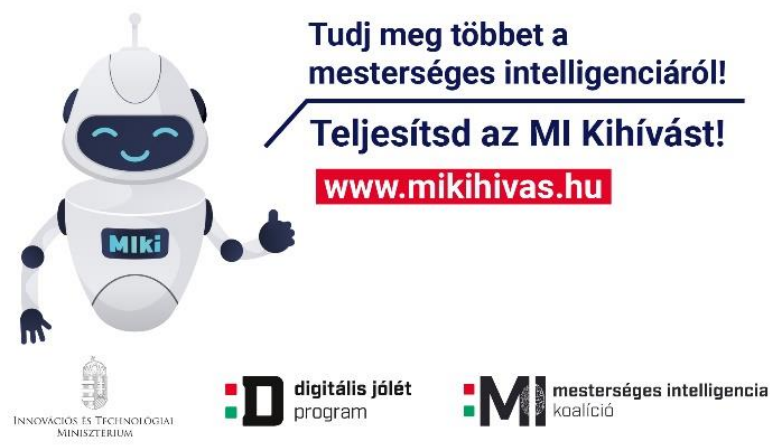


Az Innovációs és Technológiai Minisztérium kezdeményezésére 2018-ban létrejött Mesterséges Intelligencia (MI) Koalíció a hazai MI ökoszisztéma szakmai és konzultációs fóruma, amely a Digitális Jólét Program keretében végzi tevékenységét.

\section{- digitális jólét program}

\section{- 1 mesterséges intelligencia - Woalíció}

Az MI Koalíció összeköti a mesterséges intelligenciával foglalkozó gazdasági, akadémiai és kormányzati szereplőket a magyar gazdaság és társadalom MI-forradalomra való felkészítése céljából.

Emellett tudatosító kampányokkal, interaktív kiállításokkal és oktatási programokkal igyekszik közelebb hozni a nagyközönséghez a hazai MI-alapú fejlesztéseket.

Az MI Koalíció küldetése, hogy:

- hazánk az Ml fejlesztések terén az európai élvonalba kerüljön;

- az Ml alapú fejlesztések elterjedésével és alkalmazásával erősödjön a hazai vállalkozások versenyképessége;

- a magyar startupok és kkv-k nagy arányban vegyenek részt Ml fejlesztésekben, akár nagyvállalati, egyetemi vagy nemzetközi partnerségben;
- az állam a nemzeti adatvagyon átgondolt hasznosításával, illetve az Ml-megoldások fel-használójaként maga is vegye ki a részét az Ml-ökoszisztéma fejlesztéséből.

Az MI Koalíció tagjai között található a hazai vállalati, egyetemi, kutatói és kormányzati szféra legjava. Jelenleg 330 tagszervezet, több mint 1000 szakértő és 6 munkacsoport vesz részt a munkájában. A platform folyamatosan bővül.

Az MI Koalíció egyik jelenleg futó projektje az MI Kihívás. Az MI Kihívással célunk, hogy a társadalom legalább 1\%-a, 100 ezer magyar polgár szerezzen alapismereteket a mesterséges intelligenciáról online kurzus útján, 1 millióan pedig kiállítások, rendezvények, ismeretterjesztő anyagok, versenyek, és e honlap segítségével kerüljenek közelebb a technológiához.

\section{AZ MI KIHÍVÁS JELLEMZÖI}

Az MI Kihívás egy 2-3 óra alatt teljesíthető „Bevezetés a Mesterséges Intelligencia világába" című online kurzus elvégzését jelenti. A

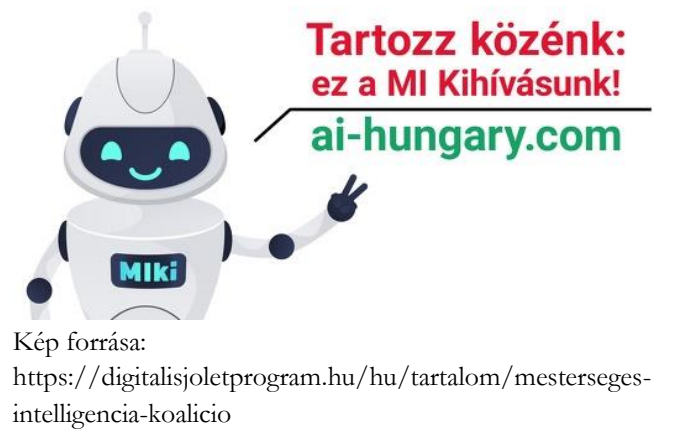




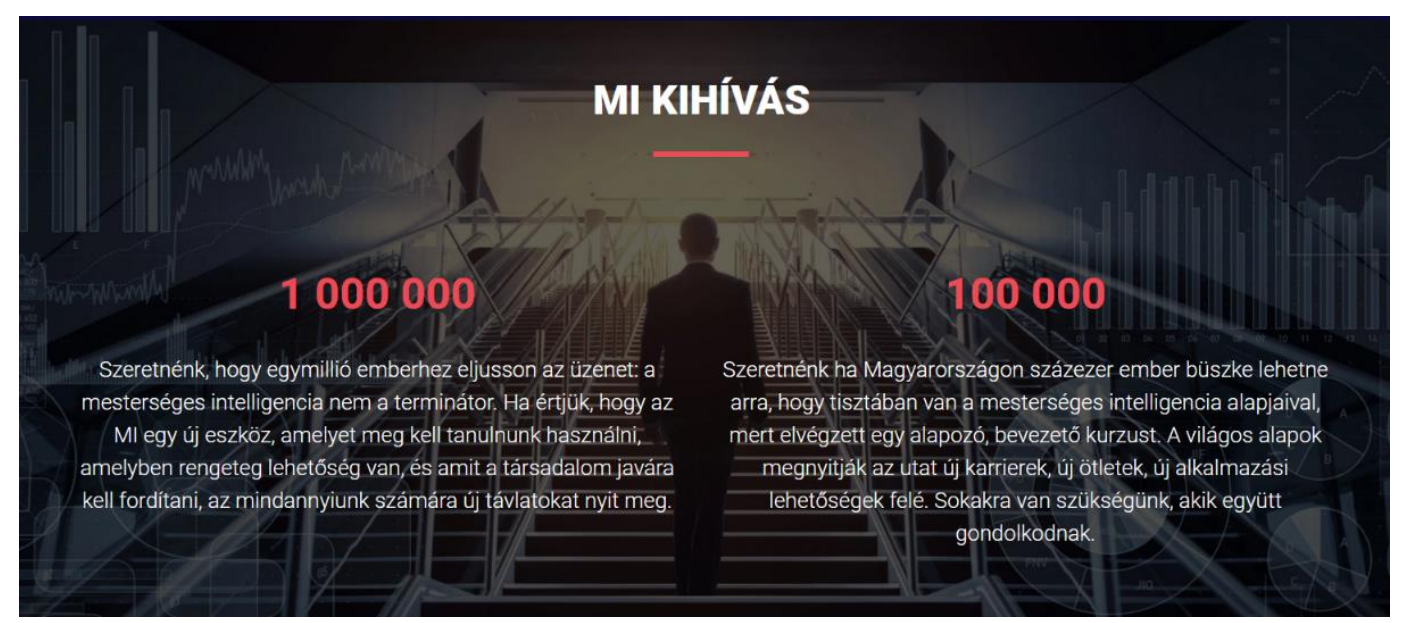

Kép forrása: https:// ai-bungary.com/ hu/tartalom/ mi-akademia

kurzus az ELTE szakembereinek munkája. A jelenleg elérhető alapozó szintet a közeljövőben további specifikus kurzusok követik, amelyek még szélesebb körű ismereteket adnak. A kurzus interaktív ismeretterjesztő tartalmakat, mindennapi és üzleti felhasználási eseteket is tartalmazó egymásra épülő ismeretanyag. Mobil eszközről is elérhető, de sokkal élvezhetőbb számítógépről, vagy laptopról.

\section{Az. MI Kibivás teljesitéséhez sqü̈kséges idôtartam}

Körülbelül három óra alatt teljesíthető a „Bevezetés a Mesterséges Intelligencia világába" kurzus, de bármikor megszakítható. Újbóli bejelentkezés esetén ott folytatható, ahol abbamaradt a kitöltés. A beiratkozástól számítva 2 hétig érhető el a kurzus. Aktívan legfeljebb 10 órát lehet eltölteni vele, utána kiléptet a rendszer.

\section{Az MI Kibivás teljesitésének dija}

A képzésen való részvétel ingyenes. Célja áttekintést nyújtani a mesterséges intelligencia legfontosabb ismérveiről, felhasználási lehetőségeinek bemutatása.

\section{Az MI Kibivás teljesitésének lépései}

1. lépés: az MI Kihívás felhívása itt érhető el: https://ai-hungary.com/hu/tartalom/miakademia/ertsd-meg\#kihivas

2. lépés: belépés az online kurzust kezelő Nexius Learning felületre. Ez megtehető az 1. lépésben közölt oldalon keresztül vagy közvetlenül az alábbi link felkeresésével: https://home.nexiuslearning.com/app/cours es/registered

3. lépés: a Nexius Learning-en külön regisztrálni kell, amit a bejelentkezés mellett 
bal oldalon a Regisztráció gombra kattintva lehet megtenni. Megjegyzés: a kurzus elvégzését követően az oklevél a regisztráláskor megadott névre lesz kiállítva.

4. lépés: a „Bevezetés a Mesterséges Intelligencia világába” kurzus az „Ajánlott kurzusaim" között jelenik meg, röviddel a bejelentkezést követően. A kurzusra történő jelentkezést követően a „Kurzusaim” közé kerül át.

5. lépés: az MI Kihívás, vagyis a „Bevezetés a Mesterséges Intelligencia világába” kurzus elvégzése. Majd az erről szóló oklevél letöltése.

\section{Felhasznált források:}

Értsd meg! (Weboldal a Mesterséges

Intelligencia Koalíció honlapján belül). Letöltés: 2021.01.29. Web: https://aihungary.com/hu/tartalom/miakademia/ertsd-meg

GYIK (Weboldal a Mesterséges Intelligencia Koalíció honlapján belül). Letöltés: 2021.01.29. Web: https://aihungary.com/hu/tartalom/gyik

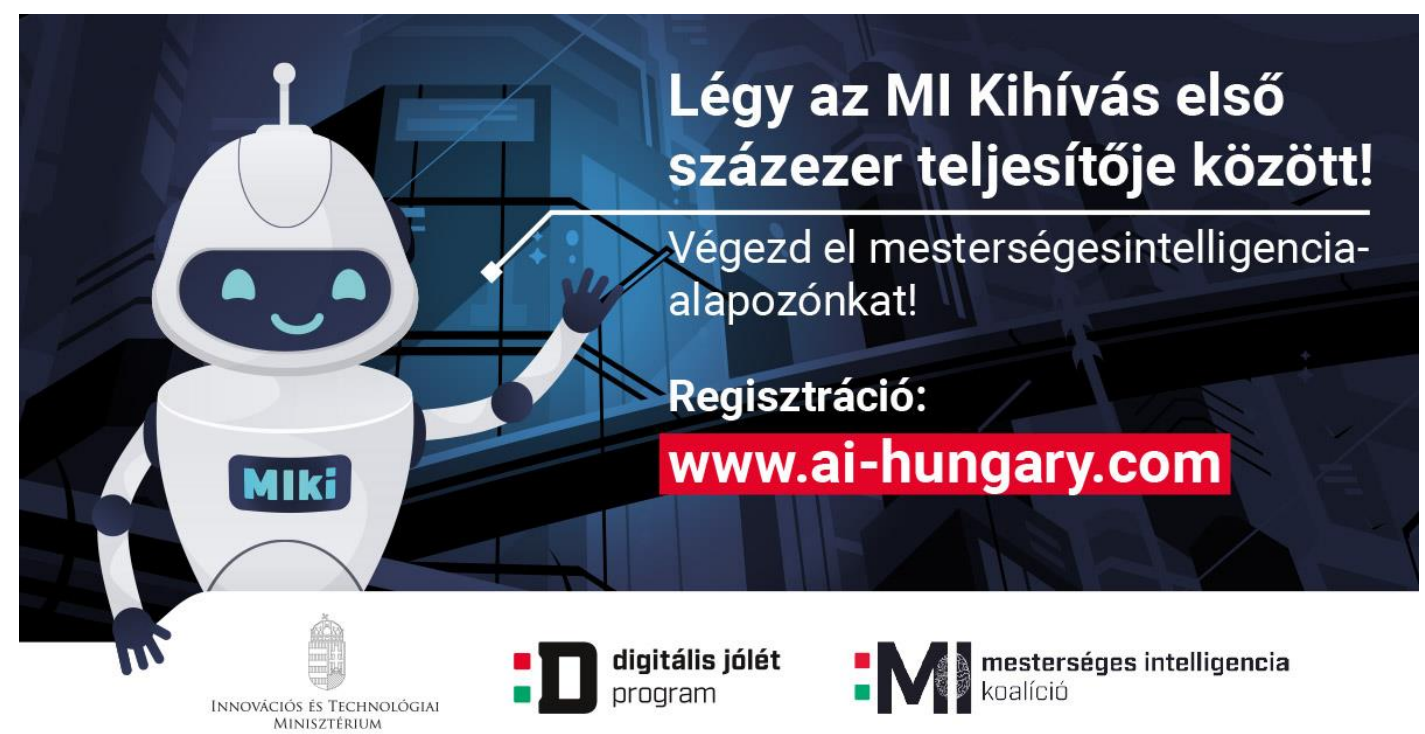




\section{ERDŐTÜZEK DINAMIKÁJÁNAK VIZSGÁLATA \\ A MEDGYESSY FERENC GIMNÁZIUMBAN}

\section{Szerzők:}

Borbélyné Bacsó Viktória (PhD)

Medgyessy Ferenc Gimnázium, Múvészeti Szakgimnázium és Technikum

Szabó Dániel Dénes

Medgyessy Ferenc Gimnázium, Múvészeti Szakgimnázium és Technikum

Farkas Máté János

Medgyessy Ferenc Gimnázium, Múvészeti Szakgimnázium és Technikum

Ujvári Balázs (PhD)

Debreceni Egyetem

Első szerző e-mail címe: bacsoviktoria@gmail.com

\section{Lektorok:}

Kelemen Lajos (PhD)

Okoskocka Kft.

Szabóné Dr. Balogh Ágota (PhD)

Gál Ferenc Egyetem

...és további két anonim lektor

\section{Absztrakt}

Ez az összefoglaló egy olyan projektet mutat be, amelyben középiskolás diákok teszteltek szenzorokat egy erdőtüzek esetén adatgyújtésre képes mérōállomás prototípusához. E méróállomás autonóm kommunikációra képes és szükség esetén le lehet dobni egy helikopterról.

Kulcsszavak: erdőtúz, mérés, érzékelő

Diszciplinák: informatika, fizika, biológia

\section{Abstract \\ EXAMINING THE DYNAMICS OF FOREST FIRES \\ IN THE 'MEDGYESSY FERENC GIMNÁZIUM'}

This summary shows a project in which high school students tested sensors for a prototype of a measuring station that can collect data in forest fires. This measuring station can make autonomous communication, and that can be dropped from a helicopter if needed.

Keywords: forest fire, measurement, sensor

Disciplines: informatics, physics, biology 
Borbélyné Bacsó Viktória, Szabó Dániel Dénes, Farkas Máté János és Ujvári Balázs (2021): Erdőtüzek dinamikájának vizsgálata a Medgyessy Ferenc Gimnáziumban. Mesterséges intelligencia - interdiszciplináris folyóirat, III. évf. 2021/1. szám. 107-110. doi: 10.35406/MI.2021.1.107

Egyre nagyobb kárt okoznak az erdőtüzek. Éves szinten 3,4 millió négyzetkilométer zöld területet pusztítanak el (Bodnár, 2017, v.ö.: Spotts, 2011). A levegőbe kerülő szállópor az egészségügyi határérték fölötti mennyisége komoly tüneteket okozhat: károsíthatja a tüdőt, növelheti a szívroham és a stroke kockázatát. Sajnálatos módon jelenleg nem létezik az erdőtűz frontvonalának feltérképezésére szolgáló, terepi közvetlen mérést megvalósító eszköz, amelynek segítségével a lángok terjedését egyszerűbben lehetne feltartóztatni.

A Medgyessy Ferenc Gimnázium, Művészeti Szakgimnázium és Technikum diákjai az Emberi Erőforrások Minisztériuma által biztosított Útravaló/Út a tudományhoz (ÚT2020-0005) ösztöndíjprogramnak köszönhetően ösztöndíjasként foglalkozhattak e nem mindennapi problémával.
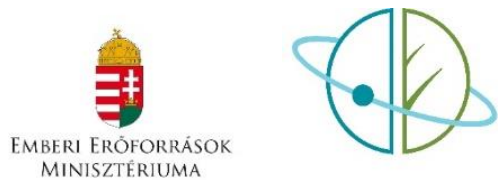

ÚT A TUDOMÁNYHOZ
Öt tanuló autonóm kommunikációra képes, helikopterről ledobható (v.ö.: Kós és Komjáthy, 2012) szenzoros mérőállomás prototípusának elkészítéséhez szükséges szenzorok tesztjét végezte el. A tervezett eszközön hőkamera, hőmérséklet, páratartalom, szállópor szenzorok (v.ö.: Szabó és Pirint, 2020) és mikrofon szolgál majd az azonnali adatgyüjtésre. A tervek szerint a prototípus egészen a megsemmisülés pillanatáig képes lesz kommunikációra és a tűzrôl begyưjtött információk továbbítására. Hogy a kommunikációra a mobil internet, netán az okos mérésre adekvátabb lehetőséget adó alacsony energiaigényű, nagy hatótávolságú, vezeték nélküli LoRa-rendszer biztosít majd lehetőséget, az a következő tanévre is átnyúló újabb vizsgálatoktól függ.

A mérésre a diákok a Medgyessy Ferenc Gimnáziumban és a Debreceni Egyetem Fizikai Innovációs Kutatóműhelyében készültek fel (Borbélyné, 2020), miközben szenzorokkal ismerkedtek, forrasztottak, programoztak, mérnöki munkát végeztek (1. ábra).

A kutatás dr. Ujvári Balázs egyetemi adjunktus és Borbélyné dr. Bacsó Viktória középiskolai fizikatanár irányításával folyt. A projekt megoldása során a mentorok egy olyan problémára, illetve annak elvi megoldására próbálták felhívni a tanulók figyelmét, amely az éghajlat változásával közvetlenül vagy közvetett módon emberek egyre nagyobb tömegének egészségét veszélyeztetheti. 
1. ábra: Munka köz̧ben. Forrás: a Szerzőke

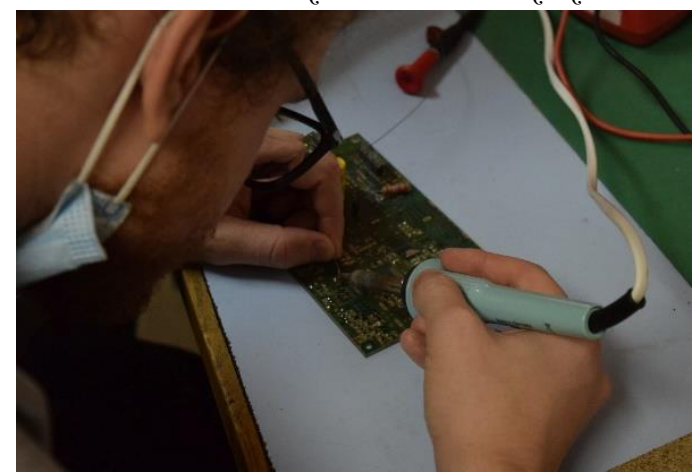

Eközben a diákok természet-tudományos, mérnöki és informatikai kom-petenciáik is jelentős mértékben fejlődtek.

A munka izgalmasabb szakaszában a tanulók az iskola udvarán a szabályokat betartva, a hatóságoktól a megfelelő tűzgyújtási engedélyt minden alkalommal kikérve gyújtottak „erdőtüzet” (2. ábra).

Különféle fafajták ágait elégetve hőkamerával figyelték a tűz hőmérsékletét. Megvizsgálták, hogy milyen összefüggés van az égő fa fajtája, a tűz hőmérséklete és a tűz hangja közt.

Miközben felvették a tűz hangját, meghatározták a frekvencia spektrumát, illetve azonosították a jellemző hangokat, amelynek kalibrációjához egy furulya hangjait használták, mint ismert frekvenciájú hangforrást (3. ábra)

Megfigyelték, hogy a tűz hőmérséklete, amit csak szűk határok közt tudtunk változtatni, nem befolyásolta a jellemző frekvenciákat, csak a hangok amplitúdóját, azaz egy fajta ág
2. ábra: A vizsgálatokhoz. szüleséges „erdôtür, szimuláciō" és méröeszközök (forrás: a Szerzőo)
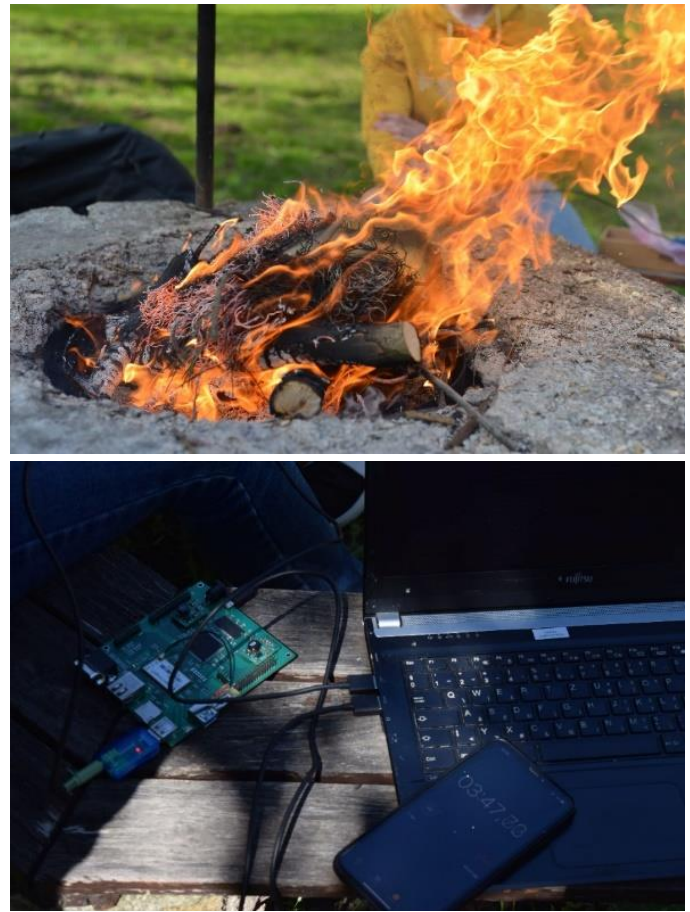

3. ábra: Kalibráció furulyával. Forrás: a Szerzọo

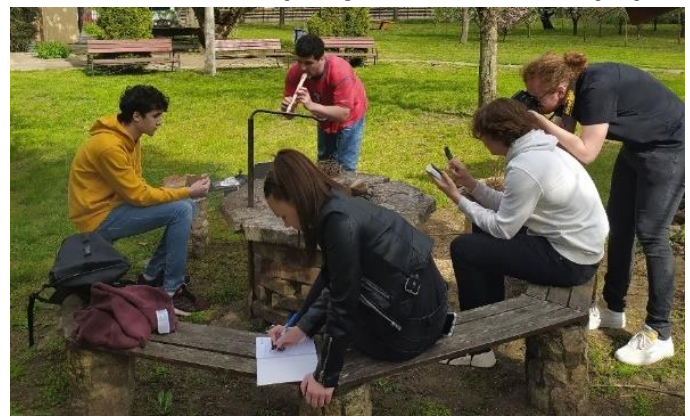


ugyanúgy ropogott a tüzben, csak magasabb hőmérsékleten hangosabban, aktívabban jelent meg az adott hang.

A diákok a mérések során azt is megfigyelték, hogy legtöbb esetben egyenesen arányosan növekszik a szállópor és a hőmérséklet értéke, azonban néhol ez mutat eltéréseket. Az adatokat a tanulók jelenleg is értékelik. A szállópor mérése azért is volt különösen fontos számukra, mert egy tűzoltás szempontjából releváns adatokat szolgáló rendszert szeretnének elkészíteni. A kapott értékekkel könnyen meghatározható egy füstszűrő élettartama az adott tűzben, így ennek túltelítődése nem válik veszélyessé.

A tanulók feltételezése szerint műszerüket az erdőtűz frontvonala elé helyezve, az összegyújtött adatokból következtetni lehet a tûz tulajdonságaira, megállapítható, hogy milyen gyorsan mozog a tüz és épp milyen fafajták égnek benne. Feltehetően ezzel előre lehetne jelezni, hogy milyen ütemben fognak a lángok a következő percekben haladni

A probléma fontosságára a tanulók a Debreceni Egyetem Fizikai Innovációs Kutatómúhelyének év végi konferenciajján szélesebb hallgatói és oktatói tömegek előtt is felhívták a figyelmet. S hogy nem csak a diákok viselik szívükön a témát, azt az is mutatja, hogy az Útravaló program anyagi támogatás nyújtott a kivitelezéshez, a
Sensirion cég pedig szenzorokkal segítette a munkát.

\section{Irodalom}

Bodnár L. (2017): Erdőtűz megelőzés korszerű módszer segítségével. Hadmérnök, XII. évf., 1. különszám (2017. július). 5969.

Borbélyné Bacsó Viktória (2020): Fizikai Innovációs Kutatóműhely - Középiskolás diákok kutatómunkája Debrecenben. OxIPO - interdiszciplináris tudományos folyóirat, 2020/1, 85-87. doi: 10.35405/OXIPO.2020.1.85

Kós GY. és Komjáthy L. (2012): Erdőtüzek helikopteres oltása. Repüléstudományi közlemények, 242 (2012) p. 471- 482.

Spotts, P. (2011): Raging wildfires: Climate changes to blame for record season?. Letöltés: 2021.06.20. Web: https://www.csmonitor.com/Environme nt/2011/0711/Raging-wildfires-Climatechanges-to-blame-for-record-season

Szabó Dániel Dénes és Pirint Róbert Olivér (2020): Felhőben az egészségünk. Mesterséges intelligencia - interdiszcip-lináris folyóirat, II. évf. 2020/2. szám. 73-86. doi: 10.35406/MI.2020.2.73 


\section{A MESTERSÉGES INTELLIGENCIA IS SZÓBA KERÜLT A „HÖLGYEK A TUDOMÁNYBAN (2020/2021)” PROJEKT TEHETSÉG TANÁCSADÁST CÉLZÓ WORKSHOPJAIN}

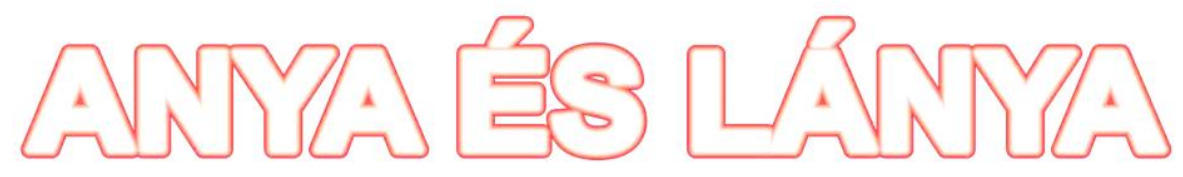

\section{INGYENES ONLINE TEHETSÉGTANÁCSADÁS}

\section{Témakörök:}

1) IDÖTAKERÉKOS TANULÁS

2) ÖSZTÖNDÍJ LEHETÖSÉGEK

3) TUDOMÁNYOS KARRIER

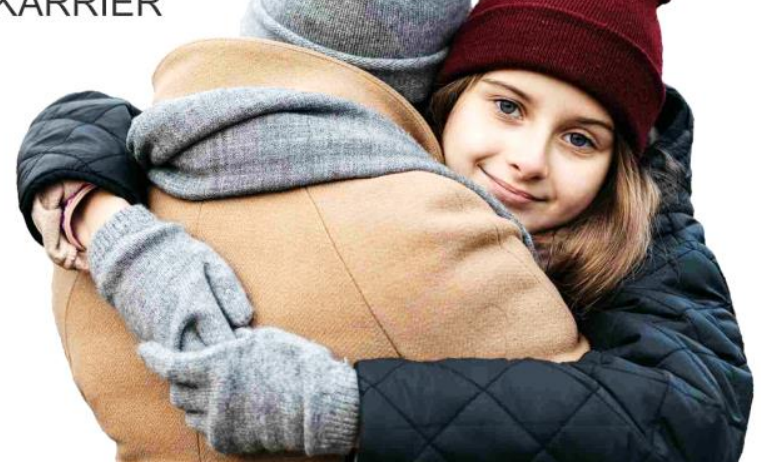

A résztvevők számára ingyenes rendezvény a $\mathrm{K}+\mathrm{F}$ Stúdió Kft. által megvalósított NTPNEER-20-0009 pályázat keretében került megrendezésre 2021.02.13, 2021.02.20, 2021.02.27., 2021.03.05. és 2021.03.13. napokon.

A tanácsadás során a hölgyek által is választható tudományos karrier egyik javasolt területeként került bemutatásra a mesterséges intelligencia (MI). Bemutatásra került, hogy miként lehet az MI kutatási cél, kutatási eszköz, vagy a világ és a mesterséges intelligencia közötti kölcsönhatásra vonatkozó tág kutatási téma.

\section{Támogatók:}

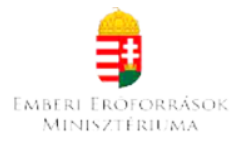




\section{AZ „INNOVÁCIÓS STÚDIUM (2020/2021)” PROJEKT ÉS A MESTERSÉGES INTELLIGENCIA}

Projekt címe: „Innovációs Stúdium 2020/2021”

Tehetséggondozó karakterisztika: teljesítményre ösztönző, gazdagító jellegű tehetséggondozó program

Megvalósító: K+F Stúdió Kft. (www.kpluszf.com)

Támogató: Nemzeti Tehetség Program (pályázati azonosító: NTP-PKTF-20-0009).

\section{$\approx \mid \begin{aligned} & \text { Nemzeti } \\ & \text { Tehetség Program }\end{aligned}$}

\section{A projekt fóbb tartalmi elemei:}

- 30 órás tehetséggondozó program,

- az „Innováció és vállalkozás létrehozása” workshop,

- virtuális kiállítás szervezése és megvalósítása,

- külföldi trénerek bevonásával megvalósuló tréning,

- fiatal tehetségek előadóként történő bevonása nemzetközi konferenciákba,

- fiatal tehetségek számára publikációs lehetőségek biztosítása.

\section{A projekt kapcsolata a mesterséges intelligencia témával:}

- az „MI mint cél” típusú kutatások ösztönzése: elsősorban az informatika, matematika, filozófia, pszichológia iránt érddeklődő fiatalok számára javasolt kutatási téma, aminek célja az MI-vel kapcsolatos tudás bővítése, MI-vel kapcsolatos innovációk megalapozása;

- az „MI mint eszköz” jellegû kutatások facilitálása: bármely diszciplina iránt érdeklődő fiatal számára javasolható az MI kutatási eszközként történő felhasználása;

- az „MI és a világ kölcsönhatása” témájú kutatások elősegítése: ez a kutatási téma bármely diszciplina felől megközelíthető. 